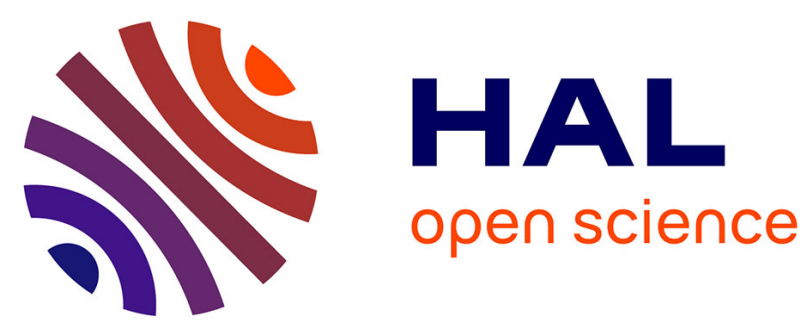

\title{
Crystallization of primitive basaltic magmas at crustal pressures and genesis of the calc-alkaline igneous suite: experimental evidence from St Vincent, Lesser Antilles $\operatorname{arc}$
}

Michel Pichavant, Ray Macdonald

\section{To cite this version:}

Michel Pichavant, Ray Macdonald. Crystallization of primitive basaltic magmas at crustal pressures and genesis of the calc-alkaline igneous suite: experimental evidence from St Vincent, Lesser Antilles arc. Contributions to Mineralogy and Petrology, 2007, 154, pp.535-558. 10.1007/s00410-007-0208-6 . insu-00170304

\section{HAL Id: insu-00170304 \\ https://hal-insu.archives-ouvertes.fr/insu-00170304}

Submitted on 23 Oct 2007

HAL is a multi-disciplinary open access archive for the deposit and dissemination of scientific research documents, whether they are published or not. The documents may come from teaching and research institutions in France or abroad, or from public or private research centers.
L'archive ouverte pluridisciplinaire HAL, est destinée au dépôt et à la diffusion de documents scientifiques de niveau recherche, publiés ou non, émanant des établissements d'enseignement et de recherche français ou étrangers, des laboratoires publics ou privés. 


\title{
Crystallization of primitive basaltic magmas at crustal pressures and genesis of the calc-alkaline igneous suite: experimental evidence from St Vincent, Lesser Antilles arc
}

\author{
M. Pichavant ${ }^{1}$ and R. Macdonald ${ }^{2}$ \\ (1) Institut des Sciences de la Terre d'Orléans (ISTO), UMR 6113 CNRS-UO, 1A rue de la \\ Férollerie, 45071 Orléans, France
}

(2) Environmental Centre, Lancaster University, Lancaster, LA1 4YQ, UK

M. Pichavant : Email: pichavan@cnrs-orleans.fr

\begin{abstract}
Near-liquidus crystallization experiments have been carried out on two basalts (12.5 and $7.8 \mathrm{wt} \% \mathrm{MgO}$ ) from Soufriere, St Vincent (Lesser Antilles arc) to document the early stages of differentiation in calc-alkaline magmas. The water-undersaturated experiments were performed mostly at $4 \mathrm{kbar}$, with 1.6 to $7.7 \mathrm{wt} \% \mathrm{H}_{2} \mathrm{O}$ in the melt, and under oxidizing conditions $(\triangle \mathrm{NNO}=-0.8$ to +2.4$)$. A few $10 \mathrm{kbar}$ experiments were also performed. Early differentiation of primitive, hydrous, high-magnesia basalts (HMB) is controlled by $\mathrm{ol}+\mathrm{cpx}+\mathrm{sp}$ fractionation. Residual melts of typical high-alumina basalt (HAB) composition are obtained after $30-40 \%$ crystallization. The role of $\mathrm{H}_{2} \mathrm{O}$ in depressing plagioclase crystallization leads to a direct relation between the $\mathrm{Al}_{2} \mathrm{O}_{3}$ content of the residual melt and its $\mathrm{H}_{2} \mathrm{O}$ concentration, calibrated as a geohygrometer. The most primitive phenocryst assemblage in the Soufriere suite (Fo89.6 olivine, $\mathrm{Mg}$-, Al- and Ti-rich clinopyroxene, $\mathrm{Cr}-\mathrm{Al}$ spinel) crystallized from near-primary $(\mathrm{Mg} \#=73.5)$, hydrous $\left(\sim 5 \mathrm{wt} \% \mathrm{H}_{2} \mathrm{O}\right)$ and very oxidized $(\triangle \mathrm{NNO}=+1.5-2.0) \mathrm{HMB}$ liquids at middle crustal pressures and temperatures from 1,160 to $\sim 1,060^{\circ} \mathrm{C}$. Hornblende played no role in the early petrogenetic evolution. Derivative $\mathrm{HAB}$ melts may contain up to $7-8 \mathrm{wt} \%$ dissolved $\mathrm{H}_{2} \mathrm{O}$. Primitive basaltic liquids at Soufriere, $\mathrm{St}$ Vincent, have a wide range of $\mathrm{H}_{2} \mathrm{O}$ concentrations $(2-5 \mathrm{wt} \%)$.
\end{abstract}

\section{Introduction}

Arc magmatism is the key to understanding the formation of continents and the recycling of material into the mantle. High-magnesia basalts ( $\mathrm{HMB}, \mathrm{MgO}>10 \mathrm{wt} \%$ ) form an important, though volumetrically subordinate, proportion of arc volcanic rocks (e.g., Nye and Reid 1986; Eggins 1993; Rohrbach et al. 2005). They possibly represent the primitive, mantle-derived, magmas from which the more evolved members of the arc sequence (high-alumina basaltbasaltic andesite-andesite-dacite-rhyolite) are derived by fractional crystallization \pm assimilation \pm magma mixing (e.g., Brophy 1989). They also constitute valuable sources of information on the conditions of partial melting, volatile content and thermal structure of the mantle wedge (Pichavant et al. 2002a).

The derivation of the low- $\mathrm{MgO}(\mathrm{MgO}<5 \mathrm{wt} \%)$ high-alumina basalts (HAB) typical of magmatic arcs by fractional crystallization of (near-) primary HMB has been addressed in several studies. Early experiments, performed under anhydrous conditions (Tatsumi et al. 1983; Gust and Perfit 1987; Ulmer 1989; Bartels et al. 1991; Draper and Johnston 1992), produced derivative melts resembling $\mathrm{HAB}$, although significant differences with natural compositions were noted (e.g., Draper and Johnston 1992). Sisson and Grove (1993a, b) clearly showed that the derivation of HAB-like residual melts from more primitive basaltic 
parents requires hydrous conditions. However, their experiments were performed at pressures of 1 and 2 kbar. Crystallization of arc basalts may not be restricted to such shallow depths: the generation of HAB has been commonly placed at moderate to high pressure, i.e., in the 8$10 \mathrm{kbar}$ range (e.g., Gust and Perfit 1987). Therefore, there is a need to examine the crystallization of HMB in the presence of water at pressures above 2 kbar. Grove et al. (2003) investigated the phase relations of primitive $(\mathrm{MgO}>9 \mathrm{wt} \%)$ basaltic andesite and andesite from Mt. Shasta under water-saturated conditions at 2 and 8 kbar. A further drawback of some recent papers reporting experimental data for subduction-related HMB at high pressures has been that $\mathrm{fO}_{2}$ has been unknown or poorly constrained (Bartels et al. 1991; Draper and Johnston 1992; Baker et al. 1994), or fixed at values too low for the likely crystallization conditions of arc rocks $(0<\mathrm{NNO}<2$; Gill 1981; Eggins 1993; Arculus 1994; Brandon and Draper 1996). Here, we report hydrous crystallization experiments on two primitive basalts from the Lesser Antilles arc, including a $\mathrm{HMB}$, at 4 and $10 \mathrm{kbar}$, and attempt to constrain the melt water content and $\mathrm{fO}_{2}$ conditions under which fractionation to $\mathrm{HAB}$ can proceed.

The Lesser Antilles island arc shows an unusual diversity of mafic eruptive rocks, from island arc tholeiites through calc-alkaline basalts to alkali basalts (Macdonald et al. 2000; Pichavant and Macdonald 2003). The Soufriere volcano of St Vincent is composed of calc-alkaline basalts and basaltic andesites (Heath et al. 1998; Pichavant and Macdonald 2003; Fig. 1). This volcano is also known for the frequent occurrence of gabbroic cumulate blocks (e.g., Lewis 1973a, b; Arculus and Wills 1980; Heath et al. 1998), attesting to the extensive crystallization of basaltic magmas at depth. The most primitive magmas of the Soufriere suite are represented by olivine + spinel - phyric HMB. Pichavant et al. (2002a) have shown that these magmas are primary, being at equilibrium on their liquidus with a spinel lherzolite mineral assemblage for a $\mathrm{fO}_{2}$ between $\mathrm{NNO}+1.5$ and $\mathrm{NNO}+2.3$. Multiple saturation with a lherzolitic mineral phase assemblage occurred at around $1,235^{\circ} \mathrm{C}, 11.5 \mathrm{kbar}$, for a melt with $1.5 \mathrm{wt} \% \mathrm{H}_{2} \mathrm{O}$, and at around $1,185^{\circ} \mathrm{C}, 16 \mathrm{kbar}$, for a melt with $4.5 \mathrm{wt} \% \mathrm{H}_{2} \mathrm{O}$. The Soufriere rocks offer, therefore, an excellent opportunity to test experimentally the crystallization behaviour of hydrous HMB at crustal pressures and, in particular, to test whether the associated $\mathrm{HAB}$ can be derived from $\mathrm{HMB}$ parents by fractional crystallization. In the context of the Lesser Antilles arc, the demonstration that HAB and HMB are genetically related would strengthen models of magma generation based on a single, although compositionally variable, mantle source, rather than on multiple sources occurring at different levels in the mantle wedge (Westercamp 1988).

\section{Experimental methods}

\section{Starting samples}

Two samples from the Soufriere volcano of St Vincent were investigated in this study. One (STV301) is representative of HMB erupted during the early activity of the volcano (PreSomma lavas, Heath et al. 1998; Fig. 1b). It typifies primitive lavas from the southern part of the Lesser Antilles arc (e.g., Arculus 1976; Westercamp 1988; Smith et al. 1996; Macdonald et al. 2000; Pichavant and Macdonald 2003). The other (STV315), also a Pre-Somma lava, is compositionally intermediate between Soufriere HMB and basaltic andesites (Fig. 1b). It may represent a composition along the calc-alkaline fractionation trend starting from HMB. The two samples are more primitive than mafic lavas or enclaves from recent eruptions along the arc (Fig. 1b). Recent experimental work on Lesser Antilles volcanic products has concentrated on andesite (Barclay et al. 1998; Martel et al. 1998; 1999; Rutherford and Devine 2003; Poussineau 2005), more rarely on basaltic andesite (Pichavant et al. 2002b). 
The melting phase relations of primitive lavas from Grenada have been investigated at $P<5$ kbar in the presence of water (Cawthorn et al. 1973; Graham 1981), and the liquidus phase relationships of STV301 have been examined at upper mantle pressures (Pichavant et al. 2002a).

Modal data, chemical compositions and norms for the two starting samples are given in Table 1, and representative electron microprobe analyses of phenocrysts are detailed in Table 2. STV301 is representative of the most primitive rocks of the Soufriere suite $(\mathrm{Mg} \#=77$, calculations at $\mathrm{NNO}+1$, Kress and Carmichael 1991). It contains phenocrysts of olivine (ol, $\mathrm{Fo}_{69.3-89.4)}$, spinel ( $\mathrm{sp}, \mathrm{Cr} \#=50-72$ ) and clinopyroxene (cpx, $\mathrm{Mg} \#$ up to 90, Table 2). Our interpretation of the textural relationships is that this rock is close to the point where clinopyroxene became a coprecipitating phase with olivine and spinel. STV315 is more evolved $(\mathrm{Mg} \#=69$ at $\mathrm{NNO}+1)$. Together with olivine $\left(\mathrm{Fo}_{75.4-88.5}\right)$, spinel $(\mathrm{Cr} \#$ up to 84$)$ and clinopyroxene $(\mathrm{Mg} \#=70-78)$, plagioclase $\left(\mathrm{An}_{54-94}\right)$ is an important phenocryst phase and orthopyroxene (opx, Mg\#=67-72) had just joined the phenocryst assemblage (Table 2).

\section{Experimental strategy and parameters}

Near-liquidus experiments were performed on STV301 and STV315 in the presence of added water. Barometric estimates for gabbroic cumulates from the Lesser Antilles, including cumulates from St Vincent, have yielded a wide range of pressures, between 4 and $10 \mathrm{kbar}$ (Arculus and Wills 1980), indicating crystallization of basaltic liquids at middle to lower crustal depths. In this study, most experiments have been carried out at 4 kbar, mainly because the equipment employed at this pressure allows (1) fast quench rates and (2) a sensitive adjustment of experimental $\mathrm{fO}_{2}$. Our aim was to adjust $\mathrm{fO}_{2}$ at or slightly above the NNO buffer, in agreement with the available estimates of redox conditions for Soufriere rocks (Heath et al. 1998). Exploratory experiments were also conducted at $10 \mathrm{kbar}$. Although the equipment used at this pressure did not allow rapid quench and fine $\mathrm{fO}_{2}$ adjustments, one experiment is reported in this paper, to contrast the type of phase assemblages observed at $10 \mathrm{kbar}$ (amphibole present) from those documented at $4 \mathrm{kbar}$ (amphibole absent).

Estimates of magmatic water contents in Soufriere St Vincent basalts have yielded conflicting results. On one hand, the high Wo contents of clinopyroxene phenocrysts (Heath et al. 1998) and the presence of amphibole in gabbroic cumulates (Arculus and Wills 1980) are consistent with melt $\mathrm{H}_{2} \mathrm{O}$ concentrations $>5-6 \mathrm{wt} \%$. On the other hand, glass inclusion studies (summarized in Heath et al. 1998; Pichavant et al. 2002a), pseudo-ternary diagrams (Heath et al. 1998), high pressure phase equilibria (Pichavant et al. 2002a) and phenocryst assemblages (relatively early appearance of plagioclase and presence of orthopyroxene in basalts, Heath et al. 1998) suggest melt $\mathrm{H}_{2} \mathrm{O}$ concentrations of $2-4 \mathrm{wt} \%$ maximum. Accordingly, $\mathrm{H}_{2} \mathrm{O}$ was added so as to generate concentrations $<6 \mathrm{wt} \%$ melt $\mathrm{H}_{2} \mathrm{O}$ in most experimental 4 kbar charges, the $10 \mathrm{kbar}$ charges being distinctly more hydrous (melt $\mathrm{H}_{2} \mathrm{O}$ concentrations $\sim 10 \mathrm{wt} \%$ ).

\section{Charges, containers and equipment}

About $8 \mathrm{~g}$ of each crushed rock (grain size $50 \mu \mathrm{m}$ ) was fused twice for $\geq 3 \mathrm{~h}$ at $1,400^{\circ} \mathrm{C}$ in air in Pt crucibles and with grinding in between. The glasses were ground to around $20 \mu \mathrm{m}$. Electron microprobe analyses of the glasses are in good agreement with the XRF whole-rock data (Table 1). All experiments used these glasses as starting materials and were thus crystallization experiments. 
Charges consisted of about 20-30 mg (exceptionally $50 \mathrm{mg}$ ) of finely ground glass plus added water. For each experiment, 3-4 charges differing in the mass of added water were prepared for each starting material. Therefore, the melt $\mathrm{H}_{2} \mathrm{O}$ content was the main experimental parameter. Water (distilled and deionised) was added with a microsyringe. Melt $\mathrm{H}_{2} \mathrm{O}$ concentrations (Table 3) are lower than saturation values for the melt composition and $P$ and $T$ of interest (Burnham 1979). Therefore, no vapour phase was present in the charges and all experiments are $\mathrm{H}_{2} \mathrm{O}$-undersaturated $\left(\mathrm{aH}_{2} \mathrm{O}<1\right.$, Table 3$)$.

Charges were loaded in containers made either of $\mathrm{Au}$ (run 4) or, for temperatures above $1050^{\circ} \mathrm{C}, \mathrm{Ag} 70 \mathrm{Pd} 30$ (runs 3, 6, 7, 1, Table 3) tubing. Pt was used for one charge (run 1, Table 3). Container capsules $(20 \mathrm{~mm}$ length, $2.5 \mathrm{~mm}$ internal diameter and $0.2 \mathrm{~mm}$ wall thickness) were welded shut. After welding the capsules were checked for leaks by immersion in an oil bath at $120^{\circ} \mathrm{C}$ and then weighed. They were placed in an oven for several hours before each run to distribute the water evenly in the capsules.

All experiments were performed at ISTO, Orléans, using two internally heated pressure vessels working vertically. The $4 \mathrm{kbar}$ experiments used $\mathrm{Ar}-\mathrm{H} 2$ mixtures as pressurising media, obtained by sequential loading of $\mathrm{H}_{2}$ and $\mathrm{Ar}$ at room temperature (Scaillet et al. 1992). An initial $\mathrm{H}_{2}$ pressure of around 2 bar was applied, followed by an Ar pressure of around 2 kbar. Total pressure was recorded by a transducer calibrated against a Heise Bourdon tube gauge (uncertainty \pm 40 bar, including daily fluctuations). A double winding furnace assembly was used, consisting of a main Kanthal furnace and an auxiliary Pt furnace placed within each other (Roux et al. 1994). Temperature was measured using three thermocouples (either type $\mathrm{S}$ or $\mathrm{K}$ ) and recorded continuously (uncertainty $\pm 5^{\circ} \mathrm{C}$ ). Near isothermal conditions in the $2-3 \mathrm{~cm}$ long hot spot were obtained (gradient $<5^{\circ} \mathrm{C} / \mathrm{cm}$ ). The $10 \mathrm{kbar}$ experiment was pressurized with pure Ar. Total pressure was recorded by a transducer calibrated against a Heise Bourdon tube gauge (uncertainty \pm 100 bar, including daily fluctuations). A double winding Kanthal furnace assembly was used. Temperature was measured using four type $\mathrm{K}$ thermocouples and recorded continuously (uncertainty $\pm 5^{\circ} \mathrm{C}$ ). Thermal gradients were $<2{ }^{\circ} \mathrm{C} / \mathrm{cm}$.

Run durations ranged between 13 and $25 \mathrm{~h}$, around $20 \mathrm{~h}$ on average. The $4 \mathrm{kbar}$ experiments were all rapid-quenched by using a drop-quench device, modified after Roux and Lefèvre (1992). Experimental capsules plus the $\mathrm{fH}_{2}$ sensor capsule were placed together in a thin alumina tube that served as a sample holder. The alumina tube was hung in the furnace hot spot by a thin $(0.2 \mathrm{~mm}) \mathrm{Pt}$ wire. At the end of the experiment, the Pt wire was fused electrically, allowing the sample holder to fall into the cold part of the vessel. With this device, nearly isobaric quench rates of $\sim 100^{\circ} \mathrm{C} / \mathrm{s}$ were achieved (Di Carlo et al. 2006). The $10 \mathrm{kbar}$ experiment was quenched by switching off the power supply, resulting in a quench rate of $\quad 100-200^{\circ} \mathrm{C} / \mathrm{min}$ (Prouteau and Scaillet 2003).

\section{Control of redox conditions}

Each experiment included a $\mathrm{Ni}-\mathrm{Pd}-\mathrm{O}$ sensor capsule, which served to determine the ambient $\mathrm{fH}_{2}$. These consisted of two pellets of NiPd metal mixtures (each with different Ni/Pd ratio) plus $\mathrm{NiO}$, placed in a $\mathrm{Pt}$ capsule in the presence of excess $\mathrm{H}_{2} \mathrm{O}$ (Taylor et al. 1992). Analysis of the composition of the metal phase after the experiment allows the $\mathrm{fO}_{2}$ of the sensor system

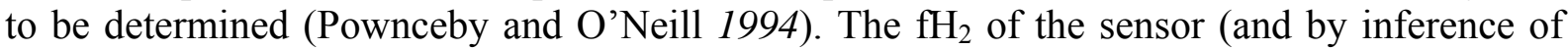
the experiment since $\mathrm{fH}_{2}$ is identical for all capsules) is then obtained from the water 
dissociation equilibrium, using the $\mathrm{fO}_{2}$ determined above, the dissociation constant of water (Robie et al. 1979) and the fugacity of pure water at the experimental $P$ and $T$ (Holloway 1987). Table 3 lists sensor compositions (mole fraction of $\mathrm{Ni}$ in the metallic phase, $\mathrm{X}_{\mathrm{Ni}}$ ) and the corresponding $\mathrm{fH}_{2}$ of each experiment.

For a given experiment (i.e. constant $P-T-\mathrm{fH}_{2}$ ), the $\mathrm{fO}_{2}$ of each individual charge is not constant but varies along with $\mathrm{aH}_{2} \mathrm{O}$. The latter was determined for each charge from the $\mathrm{H}_{2} \mathrm{O}$ content of the quenched glass, using the thermodynamic model for $\mathrm{H}_{2} \mathrm{O}$ solution in multicomponent melts of Burnham (1979). The oxygen fugacity of each charge was then calculated from the water dissociation equilibrium, using the $\mathrm{fH}_{2}$ and $\mathrm{fH}_{2} \mathrm{O}$ determined above, and the dissociation constant of water (Robie et al. 1979). The uncertainty on $\log \mathrm{fO}_{2}$ is less than $0.25 \log$ units (e.g., Scaillet et al. 1995; Martel et al. 1999; Scaillet and Evans 1999; Costa et al. 2004; Di Carlo et al. 2006). In this study, $\mathrm{fO}_{2}$ values (Table 3) are expressed as deviations from the NNO buffer ( $\triangle \mathrm{NNO}$ values), calculated at the $P$ and $T$ of interest.

\section{Analytical methods}

All run products were studied petrographically and examined by scanning electron microscopy (SEM). Two Cameca electron microprobes at the Service Commun BRGMCNRS-UO, Orléans, were used for determining the composition of starting glasses and experimental phases. Typical analytical conditions were $15 \mathrm{kV}$ (acceleration voltage), $6 \mathrm{nA}$ (sample current), 6-10 s (counting time on peak) and 1-2 $\mu \mathrm{m}$ (beam size). For glass analyses, the beam was defocussed to $8-10 \mu \mathrm{m}$. For metallic sensor phases, the acceleration voltage was $20 \mathrm{kV}$ and the sample current $20 \mathrm{nA}$. Silicate and oxide standards, and ZAF and PAP correction procedures were used. Analytical uncertainties are estimated at $2 \%$ for $\mathrm{SiO}_{2}, \mathrm{Al}_{2} \mathrm{O}_{3}$ and $\mathrm{CaO}, 3 \%$ for $\mathrm{FeO}, \mathrm{MgO}$ and $\mathrm{TiO}_{2}$, and $5 \%$ for $\mathrm{MnO}, \mathrm{Na}_{2} \mathrm{O}$ and $\mathrm{K}_{2} \mathrm{O}$. Mass-balance calculations were performed for each charge, using a linear algorithm adapted from Albarède (1995). Concentrations of all major oxides (except $\mathrm{Cr}_{2} \mathrm{O}_{3}, \mathrm{MnO}$ and $\mathrm{H}_{2} \mathrm{O}$ ) were simultaneously mass-balanced between all phases present, using the composition of starting glasses and experimental phases as input parameters. The phase proportions, bulk composition and sum of residuals $\left(\Sigma R^{2}\right)$ were computed, the calculated $\mathrm{FeO}_{\mathrm{t}}$ concentration (FeOcalc, Table 3) serving to estimate the amount of Fe loss.

The $\mathrm{H}_{2} \mathrm{O}$ concentration of three experimental glasses $(6-1,7-2,7-3$, Table 3$)$ was measured with the Cameca IMS-3F ion microprobe of CRPG, Nancy, using procedures described by Pichavant et al. (2002a). One glass (7-4, Table 3) was analyzed for $\mathrm{H}_{2} \mathrm{O}$ by Karl Fischer titration (KFT) at ISTO, Orléans (Pichavant et al. 2002b). For the other experimental glasses, the $\mathrm{H}_{2} \mathrm{O}$ content was estimated by electron microprobe using the by-difference method (Devine et al. 1995; Di Carlo et al. 2006). Glasses of known $\mathrm{H}_{2} \mathrm{O}$ concentrations (i.e., the starting glasses and those analyzed by SIMS and KFT) were used as secondary standards. These served to calibrate, for each electron microprobe session, the $\mathrm{H}_{2} \mathrm{O}$ concentration of the glass as a function of the difference between $100 \%$ and the glass major element analytical totals. Standard deviations of glass analytical totals indicates that $\mathrm{H}_{2} \mathrm{O}$ with this method is determined with an uncertainty $<0.6 \mathrm{wt} \%$ (13 charges), and between 0.8 and $1 \mathrm{wt} \%$ (four charges). 


\section{Experimental results}

A total of 22 experimental charges are reported on Table 3, 11 for STV301 and 11 for STV315. At $4 \mathrm{kbar}$, the experiments cover a temperature range from 1,200 to $1,050^{\circ} \mathrm{C}$. Melt $\mathrm{H}_{2} \mathrm{O}$ concentrations range between 1.7 and $7.7 \mathrm{wt} \% \mathrm{H}_{2} \mathrm{O}$ for STV301, and between 1.6 and $5.1 \mathrm{wt} \% \mathrm{H}_{2} \mathrm{O}$ for STV315. The experimental $\mathrm{fO}_{2}$ range is identical for the two starting samples $(\triangle \mathrm{NNO}=-0.8$ to +2.4 ; Table 3$)$. The $10 \mathrm{kbar}$ experiment was performed at a temperature near $1,050^{\circ} \mathrm{C}$ (run 1), thus allowing direct comparison with the $4 \mathrm{kbar}, 1,050^{\circ} \mathrm{C}$, experiment (run 4). However, the two $10 \mathrm{kbar}$ charges are more $\mathrm{H}_{2} \mathrm{O}$-rich $(9.4$ and $9.7 \mathrm{wt} \%$ for STV301 and STV315 respectively, Table 3) than the 4 kbar charges.

\section{Phase assemblages and quench crystallization}

Olivine, clinopyroxene, amphibole, plagioclase and magnetite occur as stable phases in both the STV301 and STV315 charges (Table 3). Olivine forms large crystals $(>100 \mu \mathrm{m})$ at high temperatures $\left(T>1,150^{\circ} \mathrm{C}\right.$ ), while, at lower temperatures (run $4,1,050^{\circ} \mathrm{C}$, Table 3 ), it tends to be smaller and/or have an irregular, rounded/embayed shape. Clinopyroxene usually occurs as small, numerous equant crystals, typically $10-15 \mu \mathrm{m}$ in size. Amphibole (10 kbar experiment only) crystallizes to abundant euhedral prismatic phases of around $20 \mu \mathrm{m}$. Plagioclase is usually $5-10 \mu \mathrm{m}$ in size, difficult to distinguish optically from the glass, and its presence was ascertained from SEM imaging. Magnetite was found only in the two $10 \mathrm{kbar}$ charges (Table 3). Cr-spinel, exclusive to the STV301 charges, crystallizes to grains up to $10 \mu \mathrm{m}$ at $1,200^{\circ} \mathrm{C}$. At lower temperatures, its size reduces to $1-2 \mu \mathrm{m}$ and detailed SEM examination is necessary to confirm its presence in run products. Orthopyroxene, present in three STV315 charges only, forms euhedral prisms larger $(20-30 \mu \mathrm{m})$ than clinopyroxene.

Despite the use of the rapid-quench device in the $4 \mathrm{kbar}$ experiments, quench phases were recognized by SEM in more than half of the charges (Table 3). At high temperature, small (1$5 \mu \mathrm{m}$ ) amphibole crystals nucleate around Cr-spinel (STV301 charges 7-2, 7-3, Table 3), the proportion of quench crystals increasing with the melt $\mathrm{H}_{2} \mathrm{O}$ content, i.e., in the order 7-2 > 7-3 (Table 3). One additional $1,200^{\circ} \mathrm{C} \mathrm{STV} 301$ charge, not reported in Table 3 and containing an initial amount of $\sim 7 \mathrm{wt} \% \mathrm{H}_{2} \mathrm{O}$, quenched to a fine intergrowth of 5-10 $\mu \mathrm{m}$ amphibole crystals. At lower temperatures, $\sim 1 \mu \mathrm{m}$ needle-like crystals are present. Nevertheless, no significant influence of quench crystallization on the composition of the melt has been detected. The very low residuals of the mass-balance calculations indicate that there is no need to include the quench phases in the chemical budgets. Fe-Mg partition coefficients between melt and olivine or pyroxenes vary significantly neither between charges with and without quench phases (compare for example the $\mathrm{Kd}^{\mathrm{Fe}-\mathrm{Mg}}$ ol-1 between charges 3-5 and 3-6, Table 3), nor between charges with different amounts of quench phases present (compare the $\mathrm{Kd}^{\mathrm{Fe}-\mathrm{Mg}}$ ol-1 between 7 2 and 7-3, Table 3). Overall, quench crystallization was of negligible importance in the $4 \mathrm{kbar}$ experiments.

The two charges from the $10 \mathrm{kbar}$ experiment totally lack textural features attributable to quench crystallization, on the basis of SEM examination. The explanation for an apparently efficient quench despite the relatively slow quench rate (see above) is probably the high $\mathrm{SiO}_{2}$ contents of the two glasses, around $64.5 \mathrm{wt} \%$, much higher than the $\mathrm{SiO}_{2}$ contents of the 4 kbar glasses (48.7-56.5 wt $\%$, Table 4). 


\section{Fe loss and mass-balance calculations}

Fe losses range from $+1 \%$ (i.e., Fe gain) to $-10 \%$, with an average of $-2 \%$ for the 22 charges reported (Table 3$)$. The highest Fe loss $(-10 \%)$ is for charge 3-3 whose glass could not be reliably analyzed (composition estimated in Table 4) because of the high proportion of crystals present $(61 \%$, Table 3$)$. The four supraliquidus charges $6-4,7-4,7-5$ and 7-6 (STV315) have Fe losses from -4 to $-7 \%$, the average Fe loss for the STV315 4 kbar charges being $-4 \%$, slightly higher than for the STV301 4 kbar charges $(-1 \%)$. This difference most probably comes from the method of calculation of Fe loss, because an increased proportion of Fe-rich phases (spinel or magnetite) is calculated to compensate for Fe loss to the capsule. Thus, any potential Fe loss in STV301 charges is hidden in increased amounts of calculated spinel, explaining why STV315 charges (which lack spinel) have slightly higher Fe losses. In other words, $-4 \%$ is probably more representative of the actual Fe loss in STV301 charges than the $-1 \%$ value calculated. These small deficits $(<-10 \%$ except for charge $3-3)$ indicate that $\mathrm{Fe}$ loss has been successfully minimized in the 4 kbar charges.

In the two magnetite-bearing 10 kbar charges, no Fe losses were detected (Table 3). To check the possibility of underestimation of Fe loss, the proportion of magnetite was calculated by mass-balancing $\mathrm{Cr}_{2} \mathrm{O}_{3}$ between the starting glass, magnetite and the experimental glass. For the STV301 charge 1-9 (ran in Pt capsule, Table 3), the proportion of magnetite obtained $(5.7 \%)$ is in agreement with that calculated with the eight major oxide algorithm (5.2\%), thus suggesting no underestimation of Fe loss. For charge 1-5 (ran in AgPd capsule), a nil proportion of magnetite was obtained, the sensitivity of the glass $\mathrm{Cr}_{2} \mathrm{O}_{3}$ analyses being insufficient to detect magnetite crystallization in this low bulk Cr STV315 charge. Therefore, the possibility of a non-zero Fe loss for charge 1-5 can not be excluded.

Residuals of the mass-balance calculations $\left(\Sigma R^{2}\right.$, Table 3$)$ are generally very low, ranging from 0.02 to 1.04 ( 0.26 on average). Only three charges have $\Sigma R^{2}>0.5$ if charge 3-3 is excluded. This compares favourably with residuals from other studies (e.g., 0.02-0.13; Gaetani and Grove 1998; 0.01 to >3, Pichavant et al. 2002a), and indicates that constant bulk silicate compositions have been essentially maintained in the two sets of experimental charges. Residuals strongly correlate with Fe loss, thus indicating that quench crystallization is not the main factor responsible for the observed chemical dispersion.

Another oxide showing significant deficits is $\mathrm{Na}_{2} \mathrm{O}$, especially in charges from experiments 1 , 4 and 3 (Table 3 ). $\mathrm{Na}_{2} \mathrm{O}$ losses $>-10 \%$ were commonly observed in the mass-balance calculations. In comparison, charges from experiments 6 and 7 yielded $\mathrm{Na}_{2} \mathrm{O}$ losses between +2 (i.e., $\mathrm{Na}_{2} \mathrm{O}$ gain) and $-8 \%$. Therefore, $\mathrm{Na}_{2} \mathrm{O}$ loss appears specific to the lowest temperature, most $\mathrm{H}_{2} \mathrm{O}$-rich charges. These are also the charges that contain the most $\mathrm{SiO}_{2}$ rich glasses and the lowest glass volume fractions, sometimes making necessary the use of an electron beam smaller than $10 \mu \mathrm{m}$. All these characteristics favour alkali migration during analysis of the glass. Consequently, $\mathrm{Na}_{2} \mathrm{O}$ values for glasses $4-1,4-2,4-3,4-5,3-2,3-6,1-$ 5 have been adjusted upwards by applying correction factors determined from the electron microprobe analysis of hydrous basaltic andesite glasses (Pichavant et al. 2002b). 


\section{Equilibrium}

All experiments from this study are of crystallization type and attainment of equilibrium has not been tested from reversals. However, several lines of evidence can be used to evaluate the approach toward equilibrium in our experiments.

1. Experimental durations ( $20 \mathrm{~h}$ on average) are in the range of previous phase equilibrium studies on hydrous basalts (Sisson and Grove 1993a, b; Barclay and Carmichael 2004; Di Carlo et al. 2006). Phase assemblages and proportions of crystals vary in a systematic and consistent way with experimental conditions. One exception is provided by charge 4-6 $\left(1,050^{\circ} \mathrm{C}, 2.2 \mathrm{wt} \% \mathrm{H}_{2} \mathrm{O}\right.$ in glass, $\left.23 \mathrm{~h}\right)$ which has a negative proportion of opx (Table 3 ), probably the result of an insufficient experimental duration.

2. Textural evidence (crystal morphologies, distribution of mineral phases) suggests no difficulty of nucleation and growth. The occurrence of quench phases indicates that, when oversaturated with mineral components, the hydrous melt readily crystallizes.

3. Crystals and glasses are compositionally homogeneous for a given charge. Standard deviations for hydrous glasses, olivines, amphiboles and plagioclases are in the same range or lower than analytical dispersions (Table 4). For pyroxenes, standard deviations for $\mathrm{Al}_{2} \mathrm{O}_{3}, \mathrm{SiO}_{2}$ and $\mathrm{MgO}$ may slightly exceed the analytical dispersion (both pyroxenes in charge $4-6$, clinopyroxene in charge $3-2$, orthopyroxene in charge 3-6). Spinel is slightly heterogeneous in charge 4-3. Experimental compositions vary in a systematic and consistent way with $\mathrm{T}, \mathrm{H}_{2} \mathrm{O}$ melt and $\mathrm{fO}_{2}$, except $\mathrm{Cr}-\mathrm{Al}$ spinels in the low-temperature charges, as detailed below.

4. Crystal-liquid exchange coefficients $\left(\mathrm{K}_{\mathrm{d}}\right)$ for olivine, clinopyroxene, orthopyroxene, amphibole and plagioclase (Table 3) agree with values from the literature under comparable conditions (discussed in detail below). This suggests that equilibrium phase compositions were obtained.

5. The low residuals from the mass-balance calculations and the lack of large (>-10\%) Fe losses in the experiments show that bulk silicate compositions were kept essentially constant. We conclude that all experiments reported in Table 3, except probably charge 46 , have closely approached equilibrium.

\section{Four kilobar phase relationships}

The 4 kbar phase relationships for the HMB STV301 are represented on a $T-\mathrm{H}_{2} \mathrm{O}$ in melt section (Fig. 2). Spinel is present in most charges, irrespective of the phase assemblage, but absent from the two driest and most reduced charges (3-3 and 6-2, Table 3). In 6-2, a large $(20 \mu \mathrm{m})$ grain of high-Cr spinel, with a lower-Cr rim, probably represents refractory material left after preparation of the starting glass and partially reacted during the experiment. Olivine and spinel are the liquidus phases. The phase diagram is characterized by a large primary ol field (compare Graham 1981). At $1,200^{\circ} \mathrm{C}$, the ol saturation curve is bracketed by charge $7-2$ ( $4.7 \mathrm{wt} \% \mathrm{H}_{2} \mathrm{O}$ ), and by the charge with $7 \mathrm{wt} \% \mathrm{H}_{2} \mathrm{O}$ added which could not be satisfactorily quenched but revealed that no phase other than melt was present at run conditions. Using the high pressure data of Pichavant et al (2002a), the ol saturation curve is constrained to be relatively flat in $\mathrm{T}-\mathrm{H}_{2} \mathrm{O}$ in melt space (Fig. 2). Saturation curves for the other phases are steeper, and in the order plag $>$ cpx. These two phases co-saturate over a small temperature interval and their saturation curves are expected to cross for a melt $\mathrm{H}_{2} \mathrm{O}$ concentration around 
$1.5 \mathrm{wt} \%$ (Fig. 2). Saturation in cpx is reached once around $12 \mathrm{wt} \%$ ol has crystallized, irrespective of temperature.

The $\mathrm{T}-\mathrm{H}_{2} \mathrm{O}$ in melt $4 \mathrm{kbar}$ isobaric section for basalt STV315 has been constructed by using all the experimental data points available, including charge 4-6. $\mathrm{Cr}-\mathrm{Al}$ spinel is absent, a result of the relatively low bulk $\mathrm{Cr}$ concentration of the starting material (Table 1). STV315 is nearly multiply saturated with respect to ol, opx, cpx and plag for $\mathrm{H}_{2} \mathrm{O}$ in melt and temperature around $3 \mathrm{wt} \%$ and $1,120^{\circ} \mathrm{C}$. For melt $\mathrm{H}_{2} \mathrm{O}$ concentrations $>3 \mathrm{wt} \%$, olivine is the liquidus phase, followed by cpx and plag. Saturation in cpx is reached once a maximum of $5 \mathrm{wt} \%$ ol has precipitated. Cpx and plag are both more abundant than ol (maximum proportion $<10 \mathrm{wt} \%$ ). For melt $\mathrm{H}_{2} \mathrm{O}$ concentrations $<3 \mathrm{wt} \%$, opx replaces ol through the $\mathrm{ol}+1=\mathrm{opx}$ peritectic reaction. The phase diagram is drawn with opx as the liquidus phase (Fig. 3). Opx is always subordinate in abundance to cpx and plag (charges 3-6 and 6-5, Table 3).

\section{Ten kilobar phase relations}

Results of the two $10 \mathrm{kbar}$ charges (one for each starting composition) are detailed in Table 3. Both are characterized by the presence of amphibole as a major phase, with proportions exceeding $30 \mathrm{wt} \%$ in the STV315 and $60 \mathrm{wt} \%$ in the STV301 charge (Table 3). The melt at equilibrium with amphibole in the two charges is very $\mathrm{H}_{2} \mathrm{O}$-rich $(>9 \mathrm{wt} \%$; Table 3$)$ and silicic ( $>64 \mathrm{wt} \% \mathrm{SiO}_{2}$, Table 4). Amphibole is accompanied by cpx and $\mathrm{mt}$, but ol and plag are both absent. These results are consistent with previous work on amphibole crystallization in hydrous basalts (Cawthorn et al. 1973; Holloway and Burnham 1972; Müntener et al. 2001; Barclay and Carmichael 2004; Grove et al. 2003). They provide further evidence that amphibole can reach saturation in high-MgO basalts.

The absence of amphibole in the 4 kbar phase assemblages (Table 3) underlines the marked contrast between the 4 and $10 \mathrm{kbar}$ results. However, amphibole is present in STV301 experiments performed at $4 \mathrm{kbar}, 1,000$ and $1,025^{\circ} \mathrm{C}$ (Pichavant et al., in preparation), and is consequently a subliquidus phase at this pressure. In contrast, at $10 \mathrm{kbar}$ and for our specific $\mathrm{H}_{2} \mathrm{O}$-rich conditions, amphibole is closer to the STV301 liquidus. Therefore, increasing pressure under near $\mathrm{H}_{2} \mathrm{O}$-saturated conditions stabilizes amphibole closer to the liquidus of high-MgO basaltic melts (Holloway and Burnham 1972; Grove et al. 2003).

\section{Compositions of experimental crystalline phases}

Olivine has Fo contents ranging from 90.5 to 75.7, generally higher in STV301 (80-90.5) than in STV315 charges (75.7-84.6, Table 4). On average, olivine contains $0.28 \mathrm{wt} \% \mathrm{CaO}$ (range $0.17-0.43 \mathrm{wt} \%$ ) and $0.25 \mathrm{wt} \% \mathrm{MnO}$ (range $0.14-0.37 \mathrm{wt} \%$ ). The olivine-liquid exchange coefficient $\left(\mathrm{K}_{\mathrm{d}}^{\mathrm{Fe}-\mathrm{Mg}}{ }_{\mathrm{ol}-1}\right)$ is $0.32 \pm 0.04$ (Table 3, $n=14$ ), calculated with $\mathrm{Fe}$ as $\mathrm{FeO}$, the glass FeO being determined from Kress and Carmichael (1991), using data in Tables 3 and 4. This $\mathrm{K}_{\mathrm{d}}$ is similar to those found in recent experimental studies of hydrous basaltic compositions (0.27-0.33, Sisson and Grove 1993a; 0.31-0.32, Pichavant et al. 2002a; $0.28+0.06$, Barclay and Carmichael 2004; $0.36+0.04$, Di Carlo et al. 2006). Olivine Fo contents systematically decrease with decreasing melt fraction and increasing ol mass fraction in the charge. Therefore, ol proportion contours (e.g., Fig. 2) are correlated to olivine Fo contours. For STV301, olivine crystallizing near the liquidus has Fo between 90 and 91 (charge 7-2, Table 4; Fig. 2). At the beginning of cpx crystallization, Fo is around 86 (charges 6-1, 3-1 and 4-1, Table 4), decreasing to 80-83 when plagioclase joins ol and cpx (charges 6- 
2, 3-2, 3-3, 4-2, 4-3, Table 4). For STV315, Fo contents are around 85 for near-liquidus olivines, 84 for cotectic ol $+\mathrm{cpx}$, and 80 for ol $+\mathrm{cpx}+$ plag (Table 4$)$.

Clinopyroxene has Wo contents ranging from 48.5 to $31.6 \%$, Fs from 5.4 to $14 \%$ and En from 42.8 to $54.4 \%$ (pyroxene end-members calculated with $\mathrm{Fe}=\mathrm{Fe}^{2+}, \mathrm{Fe}^{2+}$ and $\mathrm{Fe}^{3+}$ being computed after Lindsley 1983). Experimental cpx is aluminous (4.92-8.32 wt $\% \mathrm{Al}_{2} \mathrm{O}_{3}$ ), Tipoor (0.44-1.20 wt $\% \mathrm{TiO}_{2}$ ) and Cr-bearing (Table 4). On average, both $\mathrm{Al}_{2} \mathrm{O}_{3}$ and $\mathrm{TiO}_{2}$ are higher, and $\mathrm{Cr}_{2} \mathrm{O}_{3}$ lower, in STV301 than in STV315 charges. The 4 and $10 \mathrm{kbar}$ cpx compositions are similar. The clinopyroxene-liquid exchange coefficient $\left(K_{d}{ }_{d}^{\mathrm{Fe}-\mathrm{Mg}}{ }_{\text {cpx-l }}\right)$, calculated by averaging the data for all cpx-bearing charges, is $0.29 \pm 0.08$ (Table 3, $n=13$, calculations performed with $\mathrm{Fe}^{2+}$ in clinopyroxene and with glass $\mathrm{FeO}$ determined from Kress and Carmichael 1991). This $K_{\mathrm{d}}$ overlaps with those from recent experimental studies of hydrous basaltic compositions $(0.25-0.28$, Sisson and Grove 1993a; 0.35+0.07, Di Carlo et al. 2006).

The Ca atomic content in cpx (expressed here as Wo) progressively decreases with decreasing $\mathrm{H}_{2} \mathrm{O}$ in the coexisting melt (see also Gaetani et al. 1993; Di Carlo et al. 2006). The decrease in Wo is best seen at constant temperature, for example in the 6 charges at $1,050^{\circ} \mathrm{C}, 4 \mathrm{kbar}$ (run 4, Table 3). $\mathrm{Mg} \#$ (calculated with $\left.\mathrm{Fe}=\mathrm{Fe}^{2+}\right)$ and $\mathrm{Fe}^{3+} / \Sigma \mathrm{Fe}\left(\mathrm{Fe}=\mathrm{Fe}^{2+}, \mathrm{Fe}^{3+}\right)$ is positively correlated with melt $\mathrm{H}_{2} \mathrm{O}$ content and $\mathrm{fO}_{2}$, the highest values $\left(\mathrm{Mg} \#=89, \mathrm{Fe}^{3+} / \Sigma \mathrm{Fe}=55 \%\right)$ being found in the most $\mathrm{H}_{2} \mathrm{O}$-rich and oxidized STV301 charges at $1,050^{\circ} \mathrm{C}, 4 \mathrm{kbar}$. The $10 \mathrm{kbar}$ cpx have lower $\mathrm{Mg} \#$ and $\mathrm{Fe}^{3+} / \Sigma \mathrm{Fe}$ than the $4 \mathrm{kbar}$, a consequence of the low glass fractions at $10 \mathrm{kbar}$.

Orthopyroxene (STV315 charges) has Fs from 17.2 to $21.8 \%$ and En from 73.6 to $77.6 \%$. The Wo content ranges from 4.6 to $5.3 \%$, straddling the boundary between enstatite and pigeonite. $\mathrm{Mg \#} \mathrm{(77-82)} \mathrm{is} \mathrm{strongly} \mathrm{correlated} \mathrm{with} \mathrm{temperature,} \mathrm{the} \mathrm{most} \mathrm{magnesian} \mathrm{opx} \mathrm{being} \mathrm{found} \mathrm{at}$ $1,150^{\circ} \mathrm{C}$ (charge 6-5, Tables 3, 4). Orthopyroxene has moderately high $\mathrm{Al}_{2} \mathrm{O}_{3}$ (2.17$4.66 \mathrm{wt} \%)$, low $\mathrm{TiO}_{2}(0.2-0.32 \mathrm{wt} \%)$ and contains some $\mathrm{Cr}_{2} \mathrm{O}_{3} \quad(0.14-0.29 \mathrm{wt} \%)$. The orthopyroxene-liquid exchange coefficient $\left(K_{\mathrm{d}}^{\mathrm{Fe}-\mathrm{Mg}}{ }_{\text {opx-1 }}\right)$, calculated as for the $K_{\mathrm{d}}{ }^{\mathrm{Fe}-\mathrm{Mg}}{ }_{\text {cpx-1 }}$ and averaging the data for the 3 opx-bearing charges (i.e., including charge 4-6), is $0.28 \pm 0.02$ (Table 3), similar to those found in recent experimental studies on hydrous mafic compositions $(0.32+0.02$, Gaetani and Grove 1998; $0.34+0.04$, Pichavant et al. 2002a).

Amphibole is a hornblende $(\mathrm{hb})$ with moderately high amounts of $\mathrm{Al}_{2} \mathrm{O}_{3}\left(\mathrm{Al}^{\mathrm{IV}}=1.64-1.69\right.$ apfu), $0.79-0.83$ cations pfu in site A and very elevated $\mathrm{Mg \#}(0.81-0.82$, calculated with $\mathrm{FeO}$ $\left.=\mathrm{FeO}_{\mathrm{t}}\right)$. The hornblende-liquid exchange coefficients $\left(K_{\mathrm{d}}^{\mathrm{Fe}-\mathrm{Mg}}{ }_{\mathrm{hb}-1}\right)$, calculated with $\mathrm{FeO}$ $=\mathrm{FeO}_{\mathrm{t}}$ (in both hb and glass) are 0.31 and 0.38 , (data in Table 4), in good agreement with values from the literature $(0.30-0.38$, Sisson and Grove 1993a; 0.36, Pichavant et al. 2002b; 0.32, Grove et al. 2003).

Plagioclase An content ranges from 69.2 to 85.4 and Or from 0.4 to 1.4, overlapping between the two series of charges. The plagioclase-liquid $\mathrm{Ca}-\mathrm{Na}$ exchange coefficient $\left(K_{\mathrm{d}}^{\mathrm{Ca}-\mathrm{Na}}{ }_{\text {plag-liq }}\right)$ is strongly correlated with the $\mathrm{H}_{2} \mathrm{O}$ content of the melt, increasing from $1.3\left(1.5-2 \mathrm{wt} \% \mathrm{H}_{2} \mathrm{O}\right)$ to $4.5\left(\sim 6 \mathrm{wt} \% \mathrm{H}_{2} \mathrm{O}\right)$, in good agreement with values for basaltic compositions for comparable melt $\mathrm{H}_{2} \mathrm{O}$ concentrations (Sisson and Grove 1993a; Pichavant et al. 2002b; Di Carlo et al. 2006). Plagioclase crystallizing together with ol and $\mathrm{cpx}$ at $1,050^{\circ} \mathrm{C}$ under wet conditions $\left(\mathrm{H}_{2} \mathrm{O}\right.$ in melt $\left.=5-6 \mathrm{wt} \%\right)$ is the most calcic $\left(\sim \mathrm{An}_{85}\right)$. At $1,150^{\circ} \mathrm{C}$, and for a melt $\mathrm{H}_{2} \mathrm{O}$ content around $2 \mathrm{wt} \%$, plagioclase coexisting with either ol or opx + cpx assemblages is $\mathrm{An}_{70}$.

$\mathrm{Cr}-\mathrm{Al}$ spinel has a narrow range of $\mathrm{Cr}$, from 29 to 44 (Table 4). $\mathrm{Mg} \#$ (calculated with $\mathrm{Fe}$ $\left.=\mathrm{Fe}^{2+}\right)$ regularly increases with temperature, from $44\left(1,050^{\circ} \mathrm{C}\right)$ to $70\left(1,200^{\circ} \mathrm{C}\right)$. Both $\mathrm{Fe}^{3+} / \Sigma R^{3+}\left(\mathrm{R}^{3+}=\mathrm{Al}^{3+}, \mathrm{Cr}^{3+}, \mathrm{Fe}^{3+}\right)$ and $\mathrm{Fe}^{3+} / \Sigma \mathrm{Fe}$ increase with $\log \mathrm{fO}_{2}$, and good positive 
correlations with $\triangle \mathrm{NNO}$ are obtained if spinels from high-temperature $\left(>1,150^{\circ} \mathrm{C}\right)$ experiments (Table 4; Pichavant et al. 2002a) are plotted. Olivine-spinel equilibria (Ballhaus et al. 1991) applied to high-temperature charges 6-1, 7-2, 7-3 yield $\log \mathrm{fO}_{2}$ slightly lower than experimental values, by $0.6,0.3$ and $0.9 \log$ units, respectively. In contrast, when applied to the low-temperature $\left(<1,100^{\circ} \mathrm{C}\right)$ charges $4-1,4-2,4-3,3-1,3-2, \log \mathrm{fO}_{2}$ higher than experimental values by $2 \log$ units are obtained. In experiments 3 and 4 , spinels have low $\mathrm{Cr}$ contents, higher $\mathrm{Fe}^{3+} / \Sigma \mathrm{R}^{3+}$ and $\mathrm{Fe}^{3+} / \Sigma \mathrm{Fe}$ for a given $\Delta \mathrm{NNO}$ than the high-temperature spinels, and are too $\mathrm{Cr}$-poor and $\mathrm{Fe}^{3+}$-rich to represent equilibrium compositions. Accordingly, spinel compositions in the low-temperature experiments 3 and 4 have been corrected by increasing $\mathrm{Cr}$ and decreasing $\mathrm{Fe}^{3+}$ (at constant $\mathrm{Cr}+\mathrm{Fe}^{3+}$ ) until the calculated log $\mathrm{fO}_{2}$ (Ballhaus et al. 1991) becomes identical to the experimental value. In the following, only the corrected spinel compositions are used. Magnetites from the two $10 \mathrm{kbar}$ charges are compositionally very close, with $7 \mathrm{wt} \% \mathrm{TiO}_{2}, 3 \mathrm{wt} \% \mathrm{Al}_{2} \mathrm{O}_{3}, 3.7 \mathrm{wt} \% \mathrm{MgO}$ and $<1 \mathrm{wt} \% \mathrm{Cr}_{2} \mathrm{O}_{3}$ (Table 4).

\section{Composition of experimental glasses}

The 4 kbar glasses have basaltic to basaltic andesite compositions, with a predominance of basalts in the STV301 charges $\left(\mathrm{SiO}_{2}=48.7-53.5 \mathrm{wt} \%\right)$, and of basaltic andesites in the STV315 charges $\left(\mathrm{SiO}_{2}=52.3-56.5 \mathrm{wt} \%\right.$, Table 4$)$. The two $10 \mathrm{kbar}$ glasses are dacitic $\left(\mathrm{SiO}_{2}\right.$ $\sim 64.5 \mathrm{wt} \%$ ). Six STV301 glasses meet the compositional criteria for arc HAB suggested by Draper and Johnston (1992), viz. $\mathrm{SiO}_{2}$ from 48 to $53 \mathrm{wt} \%, \mathrm{Al}_{2} \mathrm{O}_{3}>\sim 17.5 \mathrm{wt} \%, \mathrm{CaO}>\sim$ $8.5 \mathrm{wt} \%$, and $\mathrm{MgO}<9 \mathrm{wt} \%$. The glasses from charge 7-2 and 7-3 are HMB, according to the Draper and Johnston (1992) criteria, except that the $\mathrm{TiO}_{2}$ contents (respectively 1.06 and $1.24 \mathrm{wt} \%$ ) are higher than their suggested $0.75 \mathrm{wt} \%$. Thus, the STV301 melts span the transition from HMB to HAB. Only one STV315 glass (3-5) has an HAB composition, the $\mathrm{SiO}_{2}$ contents of glasses 4-4 and 4-5 being slightly too high to fullfill the criteria above.

Glass $\mathrm{SiO}_{2}, \mathrm{TiO}_{2}, \mathrm{Al}_{2} \mathrm{O}_{3}, \mathrm{Na}_{2} \mathrm{O}$ and $\mathrm{K}_{2} \mathrm{O}$ abundances increase with progressive crystallization and differentiation, while $\mathrm{MgO}, \mathrm{CaO}$ and $\mathrm{CaO} / \mathrm{Al}_{2} \mathrm{O}_{3}$ decrease. $\mathrm{FeO}_{\mathrm{t}}$ slightly decreases during the initial stages of crystallization but shows an increase in the driest and most reduced, plagioclase-rich charges (3-6, 6-2, 6-5, Tables 3, 4). The 10 kbar glasses generally extend the trends defined by the 4 kbar glasses, except for $\mathrm{TiO}_{2}$ and $\mathrm{FeO}_{\mathrm{t}}$ which are strongly depleted as a result of massive $(>5 \mathrm{wt} \%)$ magnetite crystallization in the $10 \mathrm{kbar}$ charges. On the $\mathrm{FeO}_{\mathrm{t}} / \mathrm{MgO}$ versus $\mathrm{SiO}_{2}$ diagram (Fig. 4), the 4 and $10 \mathrm{kbar}$ glasses are dramatically separated. The STV301 and STV315 4 kbar glass trends are both slightly steeper than the tholeiitic-calcalkaline dividing line, which has been shown to correspond, in terms of $\mathrm{fO}_{2}$, to the $\mathrm{NNO}+1$ isobar (Pichavant et al. 2002b, their figure 9). The STV301 and 315 trends (Fig. 4) are consistent (Pichavant et al. 2002b) with experimental $\mathrm{fO}_{2}$ values being slightly more reduced on average than $\mathrm{NNO}+1$ (the average $\Delta \mathrm{NNO}$ is +0.5 for both sets of $4 \mathrm{kbar}$ charges) although, in detail, $\mathrm{fO}_{2}$ progressively decreases with crystallization, i.e., from lower to higher $\mathrm{FeO}_{\mathrm{t}} / \mathrm{MgO}$ (Fig. 4). In contrast, the two $10 \mathrm{kbar}$ charges have very high $\mathrm{SiO}_{2}$ and intermediate $\mathrm{FeO}_{\mathrm{t}} / \mathrm{MgO}$, plotting well into the calc-alkaline field (Fig. 4). Their position is consistent with their strongly oxidizing $(\triangle \mathrm{NNO}>+2)$ nature and specific phase assemblage (amphibole + magnetite, see Pichavant et al. 2002b).

Glass composition is primarily controlled by the type of crystalline phase assemblage present. Using $\mathrm{MgO}$ as a differentiation index, glass $\mathrm{CaO}$ and $\mathrm{Al}_{2} \mathrm{O}_{3}$ concentrations increase linearly as a result of olivine fractionation (Fig. 5a, b). The highest $\mathrm{CaO}$ concentrations (12.8 and $10.9 \mathrm{wt} \% \mathrm{CaO}$ for STV301 and STV315, respectively) are reached before cpx joins the 
liquidus (Fig. 5a). For lower $\mathrm{MgO}$ concentrations, $\mathrm{CaO}$ drops as a result of $\mathrm{cpx}$ and plag crystallization. In comparison, $\mathrm{Al}_{2} \mathrm{O}_{3}$ concentrations in glasses at equilibrium with ol $+\mathrm{cpx}$ monotonously increase with decreasing $\mathrm{MgO}$ (Fig. 5b), reaching values $>20 \mathrm{wt} \% \mathrm{Al}_{2} \mathrm{O}_{3}$ for $\mathrm{MgO}<5 \mathrm{wt} \%$ (Fig. 5b). This provides extra evidence that the view of Crawford et al. (1987), that $\mathrm{HAB}$ never exist as liquids and form instead by plagioclase accumulation, is unjustified as a general hypothesis. The $10 \mathrm{kbar}$ charges, which are plagioclase-free, have glass $\mathrm{Al}_{2} \mathrm{O}_{3}$ concentrations of $\sim 22 \mathrm{wt} \%$ and $8 \mathrm{wt} \% \mathrm{CaO}$ at $\mathrm{MgO}<1 \mathrm{wt} \%$. In contrast, at $4 \mathrm{kbar}, \mathrm{Al}_{2} \mathrm{O}_{3}$ concentrations are limited by plagioclase saturation. Since $\mathrm{H}_{2} \mathrm{O}$ suppresses plagioclase crystallization (Figs. 2, 3), the highest glass $\mathrm{Al}_{2} \mathrm{O}_{3}$ concentrations are obtained in the most $\mathrm{H}_{2} \mathrm{O}$-rich charges, obtained at $1,050^{\circ} \mathrm{C}(4-2,4-3)$ which contain the highest mass fractions of $\mathrm{ol}+\mathrm{cpx}+\mathrm{sp}$ at the point of plagioclase saturation (Fig. 6). Glass $\mathrm{Al}_{2} \mathrm{O}_{3}$ concentrations reach $21.0 \mathrm{wt} \%$ in the STV301 charges (4-3) and, in STV315, 19.1 (4-5, opx-free) and $19.2 \mathrm{wt} \%$ (46 , opx-bearing). Therefore, the attainment of elevated $\mathrm{Al}_{2} \mathrm{O}_{3}$ concentrations in residual glasses requires both high melt $\mathrm{H}_{2} \mathrm{O}$ concentrations and low temperatures.

In comparison with the 4 kbar hydrous trends from this study (see also Sisson and Grove 1993a; Gaetani et al. 1994 for similar results at $P<4$ kbar), glasses from the high-pressure and anhydrous crystallization of HMB (Draper and Johnston 1992) are characterized by lower $\mathrm{CaO}$ at a given $\mathrm{MgO}$, plotting outside the $\mathrm{HAB}$ field for typical $\mathrm{MgO}$ concentrations of 4$5 \mathrm{wt} \%$ (Fig. 5a). These results are the direct consequence of the respective crystallization sequences. Hydrous conditions stabilise olivine-only crystallization for a substantial temperature interval (Fig. 2), allowing $\mathrm{Ca}$ enrichment in residual melts. Calcic phases precipitate much earlier in high pressure and anhydrous melts (Draper and Johnston 1992): at $10 \mathrm{kbar}$, clinopyroxene + plagioclase (+orthopyroxene) join olivine at $1,275^{\circ} \mathrm{C}$ and subsequent melts show Ca depletion. Macdonald et al. (2000) divided the Lesser Antilles basaltic rocks into two groups, the key compositional difference being the $\mathrm{CaO}$ abundances at a given $\mathrm{MgO}$ level. Protracted olivine-only crystallization leads to the Ca enrichment seen in the high-Ca group, represented on Fig. 5a by the STV301 4 kbar hydrous trend; early cotectic crystallization of ol + cpx (+plag) generates melts poorer in $\mathrm{Ca}$ (the $10 \mathrm{kbar}$ and anhydrous Draper and Johnston trend on Fig. 5a).

\section{Discussion}

Hydrous basalt crystallization and genesis of the calc-alkaline suite

The earliest stage of fractionation of primitive, hydrous, low $-\mathrm{K}_{2} \mathrm{O}$ arc basalts is dominated by crystallization of $\mathrm{ol}+\mathrm{sp}$ and $\mathrm{ol}+\mathrm{cpx}+\mathrm{sp}$. High-MgO liquids such as STV301 crystallize ol + cpx over a substantial temperature interval (Fig. 2; see also Graham 1981; Sisson and Grove 1993a; Gaetani et al. 1994). In less magnesian liquids such as STV315, ol and cpx appear nearly simultaneously (Fig. 3). Plagioclase was found as a near-liquidus phase neither in STV301 nor in STV315. For $\mathrm{H}_{2} \mathrm{O}$ concentrations above either 1.5 (STV301) or 3 (STV315) wt\%, plag is the third silicate to crystallize (Fig. 2, 3). The liquid lines of descent reflect the combined effects of $\mathrm{ol}+\mathrm{cpx}$ fractionation and suppression of plagioclase crystallization (e.g., Yoder 1965; Sisson and Grove 1993a). Residual liquids at equilibrium with ol $+\mathrm{cpx}+\mathrm{sp}$ assemblages are progressively depleted in ol and cpx components, and enriched in plag (Fig. 7, 8) and qz (Fig. 8) components, essential features of the calc-alkaline differentiation trend (e.g., Grove and Baker 1984; Gust and Perfit 1987; Sisson and Grove 1993a). Thus, early crystallization of ferromagnesian silicates produces compositions typical of the more evolved members of the arc sequence. The effect of $\mathrm{H}_{2} \mathrm{O}$ on residual melt composition is directly seen at constant pressure by comparing, for STV301, charges 6-2 $\left(1.7 \mathrm{wt} \% \mathrm{H}_{2} \mathrm{O}\right)$ with 4-3 $(5.9 \mathrm{wt} \%)$ and, for STV315, charges 6-5 (1.6 wt\%) with 4-5 
(3.9 wt\%, Figs. 7, 8). Saturation in plagioclase occurs at lower normative plag in glasses with low rather than high $\mathrm{H}_{2} \mathrm{O}$ contents.

Spinel may be present during the early stages of ol + cpx fractionation, as illustrated by the STV301 charges. Fractionation of sp depletes the residual melt in $\mathrm{FeO}_{\mathrm{t}}$, to a lesser extent in $\mathrm{MgO}$, increases $\mathrm{SiO}_{2}$ and alkalis, and shifts the melt composition toward the calc-alkaline field (Fig. 4). The proportion of crystallizing sp exerts an important influence on the $\mathrm{FeO}_{\mathrm{t}} / \mathrm{MgO}$ of the melt (Fig. 4; see also Sisson and Grove 1993a; Pichavant et al. 2002b). Therefore, when $\mathrm{sp}$ is a near-liquidus phase, the compositional effects arising from the early crystallization of ferromagnesian silicates are amplified. Early crystallization of sp has been ascribed to the influence of hydrous conditions (Sisson and Grove 1993a). However, other factors such as high $\mathrm{fO}_{2}$ and bulk composition (in particular high $\mathrm{Cr}$ ) may be more effective than $\mathrm{H}_{2} \mathrm{O}$ in stabilizing spinel near the liquidus of basaltic melts. The lack of $\mathrm{sp}$ in the two STV301 charges 3-3 and 6-2 (which are the less oxidized of the STV301 charges) and in all STV315 charges (from a relatively low $\mathrm{Cr}$ bulk composition, Table 1) illustrates the importance of these two parameters.

Early hornblende crystallization will introduce major changes in the fractionation scheme above. Olivine and cpx, if present, will be resorbed (e.g., Holloway and Burnham 1972; Barclay and Carmichael 2004). In terms of major element fractionation, hb-bearing assemblages lead to a slight decrease of $\mathrm{CaO}$, and to an increase of $\mathrm{Al}_{2} \mathrm{O}_{3}$ at decreasing $\mathrm{MgO}$, similar to that observed for ol $+\mathrm{cpx}$ fractionation (Fig. 5). However, the $\mathrm{SiO}_{2}$ content of the residual liquid will be much higher as a result of hb than of ol + cpx fractionation (Fig. 4). Therefore, there should be a major difference in the silica content of residual magmas depending on the fractionation scheme, respectively $\mathrm{HAB}$ in the case of ol $+\mathrm{cpx}$ fractionation and andesites or more evolved rocks in the case of hb fractionation. A comparison between the 4 and 10 kbar glasses (Fig. 4) clearly illustrates this point. However, to affect early fractionation in hydrous basaltic melts, hornblende has to be a near-liquidus phase. This requires pressures in the lower crustal/upper mantle range, elevated $\mathrm{H}_{2} \mathrm{O}$ concentrations and appropriate melt compositions (Holloway and Burnham 1972; Grove et al. 2003).

The fact that opx occurs in STV315 but is absent from STV301 charges indicates compositional control on opx stability. The three opx-bearing charges have glass $\mathrm{SiO}_{2}$ contents of 52.6, 54.6 and $56.5 \mathrm{wt} \%$ (Table 4). This includes the two most silica-rich among the $4 \mathrm{kbar}$ glasses, and suggests that melt compositions with at least $\sim 53 \mathrm{wt} \% \mathrm{SiO}_{2}$ (i.e. basaltic andesite and more evolved) are required to crystallize opx in hydrous basaltic bulk compositions. Opx appears in virtually all natural Lesser Antilles suites, at $4 \mathrm{wt} \% \mathrm{MgO}$ (Macdonald et al. 2000). However, the opx stability field is restricted to the low- $\mathrm{H}_{2} \mathrm{O}$ in melt portion of the 4 kbar phase diagram (Fig. 3). At melt $\mathrm{H}_{2} \mathrm{O}$ contents $<3 \mathrm{wt} \%$, opx appears as a reaction product between ol and melt. At higher melt $\mathrm{H}_{2} \mathrm{O}$ contents, opx is no longer present, indicating that opx is stable only for low melt $\mathrm{H}_{2} \mathrm{O}$ concentrations in mafic to intermediate melts (see also Sisson and Grove 1993a; Martel et al. 1999; Pichavant et al. 2002b). The effect of $\mathrm{H}_{2} \mathrm{O}$ on opx stability is, in our experiments, demonstrated at constant pressure, but not at strictly constant $\mathrm{fO}_{2}$ since $\triangle \mathrm{NNO}$ increases along with increasing melt $\mathrm{H}_{2} \mathrm{O}$ content. However, Pichavant et al. (2002b) have shown that increasing $\mathrm{fO}_{2}$ at constant melt $\mathrm{H}_{2} \mathrm{O}$ concentration depresses opx stability. Therefore, both the melt $\mathrm{H}_{2} \mathrm{O}$ content and $\mathrm{fO}_{2}$ have the same type of influence on opx stability. 


\section{$\mathrm{Al}_{2} \mathrm{O}_{3}$ content of arc basaltic liquids}

The depression of plagioclase crystallization in hydrous systems leads to an enrichment of the residual melt in $\mathrm{Al}_{2} \mathrm{O}_{3}$ (Figs. 5b, 6) and Plag components (Figs. 7, 8). Therefore, a relation between the $\mathrm{Al}_{2} \mathrm{O}_{3}$ content of the residual melt and its $\mathrm{H}_{2} \mathrm{O}$ concentration is expected (Fig. 6). Hydrous conditions, when combined with low-temperatures, generate residual melts with high $\mathrm{Al}_{2} \mathrm{O}_{3}$ concentrations because ferromagnesian silicates and oxides may crystallize in large amounts before plagioclase starts to precipitate. We have empirically regressed the $\mathrm{Al}_{2} \mathrm{O}_{3}$ content of experimental liquids as a function of the melt $\mathrm{H}_{2} \mathrm{O}$ concentration, temperature and melt composition, to provide a melt-based geohygrometer applicable to arc basaltic liquids (see also Sisson and Grove 1993b).

The regression has been calibrated from a set of 34 hydrous mafic liquids mainly from low pressure experiments (32 at $\mathrm{P}<4 \mathrm{kbar}, 2$ at $10 \mathrm{kbar}$ ). The total range of melt $\mathrm{H}_{2} \mathrm{O}$ concentrations is $1.2-9.7 \mathrm{wt} \%$, with a majority between 2 and $6 \mathrm{wt} \%$. Only charges with assemblages of four and five phases have been considered to restrict the variance (Sisson and Grove 1993b). With the exception of four charges, the database comprises only plagioclasesaturated experiments because plagioclase effectively limits the $\mathrm{Al}_{2} \mathrm{O}_{3}$ concentration in the melt (Figs. 5b, 6). Exceptions include two $4 \mathrm{kbar}$ ol $+\mathrm{cpx}+\mathrm{sp}$ charges close to plagioclase saturation (4-2, 3-2, Table 3) and the two 10 kbar charges from this study (1-5, 1-9, Table 3) which have been included to extend the range of melt $\mathrm{Al}_{2} \mathrm{O}_{3}$ and $\mathrm{H}_{2} \mathrm{O}$ concentrations. Except these two $10 \mathrm{kbar}$ charges, all melts in the calibrating database have $\mathrm{SiO}_{2}<55 \mathrm{wt} \%, \mathrm{FeO}_{\mathrm{t}}$ $<10 \mathrm{wt} \%, \mathrm{MgO}>3.5 \mathrm{wt} \%$ and $\mathrm{K}_{2} \mathrm{O}<3.5 \mathrm{wt} \%$ (anhydrous basis). The formulation of the model is given in Table 5. Pressure was not included in the regression because most calibrating experiments are $<4 \mathrm{kbar}$. The regression should be seen as no more than an empirical fit of the $\mathrm{Al}_{2} \mathrm{O}_{3}$ contents of low-pressure, plagioclase-saturated, hydrous basaltic liquids as a function of temperature and melt $\mathrm{H}_{2} \mathrm{O}$ content. The correlation coefficient $\left(r^{2}\right)$ is 0.92 and the expression of Table 5 recovers the melt $\mathrm{Al}_{2} \mathrm{O}_{3}$ and $\mathrm{H}_{2} \mathrm{O}$ concentrations of the calibrating experiments with average errors of +0.3 and $+0.5 \mathrm{wt} \%$, respectively.

The average of olivine-hosted glass inclusions $\left(\mathrm{SiO}_{2}<54 \mathrm{wt} \%\right)$ in the 1979 Soufriere eruption products (Devine and Sigurdsson 1983) yields calculated melt $\mathrm{H}_{2} \mathrm{O}$ concentrations in the range $6.1-4.0 \mathrm{wt} \%$ for temperatures between 950 and $1,100^{\circ} \mathrm{C}$ (Fig. 9). For an interstitial glass in a gabbroic cumulate (Lewis 1973a), the calculated melt $\mathrm{H}_{2} \mathrm{O}$ concentration is $4.6 \mathrm{wt} \%$ at $950^{\circ} \mathrm{C}$. Values between $4.4\left(1,100^{\circ} \mathrm{C}\right)$ and $6.6\left(950^{\circ} \mathrm{C}\right) \mathrm{wt} \% \mathrm{H}_{2} \mathrm{O}$ are obtained for one basaltic inclusion trapped in olivine from the Kick'em Jenny submarine volcano (Devine and Sigurdsson 1995). Representative glass inclusions from a large data set on St Vincent island (Bouvier et al., written communication 2006) yield a total range of $\mathrm{H}_{2} \mathrm{O}$ concentrations between 4.4 and $7.5 \mathrm{wt} \%$ (Fig. 9). Therefore, the $\mathrm{Al}_{2} \mathrm{O}_{3}$ in melt regression establishes the presence of relatively $\mathrm{H}_{2} \mathrm{O}$-rich basaltic liquids at St Vincent and elsewhere in the Lesser Antilles, and in other arcs as well (Fig. 9). Note that plagioclase saturation is assumed in the calculations above. If this is not the case, then the $\mathrm{H}_{2} \mathrm{O}$ concentrations are maximum values.

\section{Early petrogenetic evolution of the Soufriere suite}

Magmas sustaining the activity of Soufriere in the last few thousand years have dominantly been low-MgO basalts and basaltic andesites (Graham and Thirlwall 1981; Bardintzeff 1983; Devine and Sigurdsson 1983; Heath et al. 1998; Fig. 1). There is agreement that these magmas are derived from primitive basaltic parents (Graham and Thirlwall 1981; Bardintzeff 1983; Devine and Sigurdsson 1983; Heath et al. 1998). Heath et al. (1998) have suggested 
that HMB similar to the older erupted (STV301) are parental to the recent basaltic andesites (see also Graham and Thirlwall 1981). Below, our experimental results are combined with existing mineralogical and petrological data (Graham and Thirlwall 1981; Marcelot et al. 1981; Heath et al. 1998) to constrain early differentiation in the Soufriere lavas.

Compositions of olivine from the Soufriere suite are compared with experimental olivines in Fig. 10. The natural olivines show a large variation in Fo content, from $<60$ to about 90 . Olivines with Fo $>88$ occur in lavas of various types and eruption ages (Heath et al. 1998). In these different rock types, olivines have identical maximum Fo contents (89.4 in HMB; 89.6 in basalts; 89.7 in basaltic andesites, Marcelot et al. 1981; Heath et al. 1998), suggesting parental melts with constant $\mathrm{Mg \#}$. The occurrence of Fo-rich olivines in rocks that are too evolved on the basis of olivine-liquid equilibrium (i.e., Fo88.5 in STV315, much higher than the maximum in experiments, $\mathrm{Fo}_{84.6}$ ), suggests that primitive magmas, presumably $\mathrm{HMB}$, are involved in the genesis of these rocks, and indicates transfer of phenocrysts from primitive to more evolved magmas, most probably during magma mixing.

Olivines with $\mathrm{CaO}<0.1 \mathrm{wt} \%$ include a primitive group with Fo up to 89.7 and $\mathrm{Ni}$ up to $0.38 \mathrm{wt} \%$ (Marcelot et al. 1981; Heath et al. 1998). On Fig. 10, these five compositions nearly overlap with olivines from the peridotite xenoliths of Grenada (Parkinson et al. 2003). We interpret these ol compositions are representing crystals disaggregated from mantle rocks, presumably xenoliths, and entrained in the Soufriere magmas.

The maximum Fo in STV301 experiments (90.5) exceeds that of olivine phenocrysts (89.6). Calculated Fo of liquidus ol range between 90.3 (NNO) to 93 (NNO + 2.5), using STV301 glass composition from Table $4, K_{\mathrm{d}}^{\mathrm{Fe}-\mathrm{Mg}}{ }_{\mathrm{ol}-1}$ from this study and melt $\mathrm{FeO}$ from Kress and Carmichael (1991). Therefore, ol phenocryst compositions require that the parental basaltic melts at Soufriere are slightly less primitive than STV301. The composition of a parental melt has been calculated by incrementally subtracting olivine with equilibrium $\mathrm{Fe} / \mathrm{Mg}$ ratio from the STV301 bulk composition until a Mg\# in equilibrium with Fo $_{89.6}$ is reached. The resulting melt (PAR1, Table 1) is a HMB with a Mg\# (73.5) slightly lower than STV301 (76.8 at $\mathrm{NNO}+1)$.

Natural cpx have $\mathrm{Mg} \#$ (calculated with $\mathrm{Fe}=\mathrm{Fe}^{2+}$ ) ranging from 66 to 91, mostly $<80$ (Graham and Thirlwall 1981; Marcelot et al. 1981; Heath et al. 1998), indicating that a majority of cpx in the Soufriere suite crystallized from relatively evolved melts. Cpx in STV301 have Mg\# up to 90 (Fig. 11). One critical observation is the splitting of the most magnesian $(\mathrm{Mg} \#>85)$ natural cpx population into two compositionally distinct groups, based on their $\mathrm{Al}_{2} \mathrm{O}_{3}$ and $\mathrm{TiO}_{2}$ (Fig. 11). The Al- and Ti-rich cpx (group 1, maximum $\mathrm{Mg \#}=90$ ) are well matched by the experimental cpx compositions, and are interpreted as early phenocrysts from primitive basaltic liquids. In contrast, the Al- and Ti-poor compositions (group 2, maximum $\mathrm{Mg} \#=91$ ) have not been experimentally reproduced. Both groups are Cr-rich (group 1: $0.69-0.99$; group 2: $0.22-0.87 \mathrm{wt} \% \mathrm{Cr}_{2} \mathrm{O}_{3}$ ), but $\mathrm{Fe}^{3+} / \Sigma \mathrm{Fe}$ at equivalent $\mathrm{Mg \#}$ is distinctly higher in group 1 than in group $2 \mathrm{cpx}$. Since group 2 extends to the cpx compositions in the peridotite xenoliths from Grenada (Fig. 11; Parkinson et al. 2003), these crystals are interpreted as coming from similar peridotite xenoliths and incompletely reequilibrated in the Soufriere lavas.

Experimental charges in which the composition of magnesian group $1 \mathrm{cpx}$ phenocrysts is approached constrain the composition of cotectic melts. The melt in charge 4-1 can be taken as the cotectic melt at the point of cpx saturation since that charge has the lowest proportion of cpx. From there, the composition of parental Soufriere melts can be calculated by 
incrementally adding olivine with equilibrium $\mathrm{Fe} / \mathrm{Mg}$ ratio to glass $4-1$ until a $\mathrm{Mg} \#$ at equilibrium with $\mathrm{Fo}_{89.6}$ ol is reached. The parental melt obtained is again a HMB (PAR2, Table 1), slightly higher in $\mathrm{Al}_{2} \mathrm{O}_{3}$ and $\mathrm{MgO}$, and lower in $\mathrm{FeO}_{\mathrm{t}}$ and $\mathrm{CaO}$ than PAR1.

Soufriere spinel compositions are Cr- and $\mathrm{Fe}^{3+}$-rich (Fig. 12; Marcelot et al. 1981; Heath et al. 1998), typical of primitive arc basalts (Arculus 1978; Eggins 1993). The most magnesian varieties $(\mathrm{Mg} \#=53, \mathrm{Cr} \#=51)$ are similar to the less refractory spinels in the Grenada peridotite xenoliths (Parkinson et al. 2003). Spinels from the high-temperature $\left(>1,150^{\circ} \mathrm{C}\right.$ ) charges are more magnesian than spinels in the rocks, suggesting that these latter equilibrated at temperatures $<1,150^{\circ} \mathrm{C}$. Spinels from the low-temperature $\left(<1,100^{\circ} \mathrm{C}\right)$ charges approach the most magnesian and aluminous spinels in STV301 (Fig. 12).

In summary, phenocrysts in the Soufriere suite include a distinctive primitive assemblage with ol $\left(\mathrm{Fo}_{89.6}\right)$, cpx $(\mathrm{Mg} \#=90)$ and $\mathrm{Cr}-\mathrm{Al} \mathrm{sp}(\mathrm{Mg} \#=53, \mathrm{Cr}=51)$, which marks the earliest stages of magma crystallization and differentiation. The recognition of ol and cpx with typical mantle compositions links magma generation and equilibration in the mantle and the early crystallization history. Hornblende is absent as a phenocryst in the Soufriere lavas. However, it is a major phase in the gabbroic cumulates (e.g., Lewis 1973a, b; Arculus and Wills 1980). In these cumulates, hb may coexist with ol and cpx, both of relatively low $\mathrm{Mg \#} \mathrm{(e.g.,} \mathrm{unzoned}$ $\mathrm{Mg} \# 72 \mathrm{hb}$ coexisting with $\mathrm{Fo}_{76}$ and $\mathrm{Mg} \# 84 \mathrm{cpx}$, Lewis, 1973a, b), suggesting that amphibole crystallizes relatively late. Hornblendes in the cumulates have $\mathrm{Mg \#}$ ranging from 68 to 78 with a majority in the range 70-72 (Pichavant, Maury and Macdonald, unpublished data), and thus are less magnesian than the amphiboles in the $10 \mathrm{kbar}$ charges $(\mathrm{Mg} \#=81-82$, Table 4). This indicates that the cumulate hornblendes crystallized from melts less primitive than STV301 and STV315. We, therefore, conclude that amphibole plays no role in the early petrogenetic evolution of the Soufriere suite, which is controlled by $\mathrm{ol}+\mathrm{cpx}+\mathrm{sp}$ fractionation.

\section{$\mathrm{T}-\mathrm{H}_{2} \mathrm{O}-\mathrm{fO}_{2}$ of parental Soufriere liquids: constraints from primitive phenocrysts}

In charges $4-1$ and $4-2$ at $1050^{\circ} \mathrm{C}\left(7.7\right.$ and $\left.6.3 \mathrm{wt} \% \mathrm{H}_{2} \mathrm{O}\right)$, experimental cpx have $\mathrm{Mg \#}$ nearly identical to the maximum of phenocrysts, whereas $\mathrm{Al}_{2} \mathrm{O}_{3}$ and $\mathrm{TiO}_{2}$ are both slightly lower (Fig. 11). At $1,100^{\circ} \mathrm{C}$ (charge 3-2, $4.2 \mathrm{wt} \% \mathrm{H}_{2} \mathrm{O}$ ), experimental cpx has slightly higher $\mathrm{Al}_{2} \mathrm{O}_{3}$ and $\mathrm{TiO}_{2}$ but lower $\mathrm{Mg} \#$ than the most magnesian phenocryst. Additional constraints on melt $\mathrm{H}_{2} \mathrm{O}$ content and pressure are obtained from $\mathrm{Al}^{\mathrm{VI}}$ in $\operatorname{cpx}$ (Fig. 14). The $\mathrm{Al}^{\mathrm{VI}}$ of the most magnesian cpx phenocryst is bracketed by charges 4-1 and 4-2, on one hand, and 3-2 on the other (Fig. 14). Therefore, this cpx crystallized from melts containing 5-6 wt $\% \mathrm{H}_{2} \mathrm{O}$ at $1,060^{\circ} \mathrm{C}$ (Fig. 11). Although precise constraints on pressure are lacking, the low $\mathrm{Al}^{\mathrm{VI}}$ of primitive cpx phenocrysts rule out crystallization at pressures $>10$ kbar (Fig. 14). The data at 4 kbar reproduce satisfactorily the compositional characteristics of these primitive cpx and we conclude that they crystallized in the middle crust.

Since ol is the liquidus phase for parental melts PAR1 and PAR2, olivine crystallization must necessarily begin at temperatures $>1,060^{\circ} \mathrm{C}$ and for melt $\mathrm{H}_{2} \mathrm{O}$ contents slightly $(\sim 10 \%)$ less than for cotectic conditions if a closed-system, incompatible, behaviour is assumed for $\mathrm{H}_{2} \mathrm{O}$. This is because $\sim 10 \mathrm{wt} \%$ ol must crystallize before the ol + cpx cotectic is reached (Fig. 2). Although olivine in charge $4-1\left(1,050^{\circ} \mathrm{C}\right)$ is the closest to the high-Fo end of the olivine natural trend (Fig. 10), it has a Fo (86.6) lower than the maximum of phenocrysts (89.6), confirming that the most Fo-rich olivines crystallized at temperatures $>1,050^{\circ} \mathrm{C}$. Temperatures of a minimum of $1,100^{\circ} \mathrm{C}$ are implied by the most magnesian spinel phenocryst 
in STV301 (Fig. 13a). For $T>1,050^{\circ} \mathrm{C}$ but melt $\mathrm{H}_{2} \mathrm{O}$ contents $<4 \mathrm{wt} \%$, experimental ol have $\mathrm{CaO}$ contents higher than the natural compositions (Fig. 10). An ol with Fo88.7 and $0.20 \mathrm{wt} \%$ $\mathrm{CaO}$ crystallized in one additional $4 \mathrm{kbar}$ STV301 experiment at $1,150^{\circ} \mathrm{C}$ and for $5.9 \mathrm{wt} \%$ $\mathrm{H}_{2} \mathrm{O}$ in melt (Pichavant et al., in preparation). Taking a melt $\mathrm{H}_{2} \mathrm{O}$ content of $5 \mathrm{wt} \%$, a liquidus temperature of $\sim 1,160^{\circ} \mathrm{C}$ is obtained for the parental Soufriere melts $(\mathrm{Mg} \#=73.5)$ by interpolating the liquidus temperatures for STV301 $(\mathrm{Mg} \#=76.8)$ and STV315 $(\mathrm{Mg} \#=69$, calculations at $\mathrm{NNO}+1)$. Although based on experimental data obtained at $4 \mathrm{kbar}$, this inferred liquidus temperature will not vary significantly with pressure because experiments on STV301 have shown that, between 8-15 kbar and for a melt $\mathrm{H}_{2} \mathrm{O}$ content of $4.5 \mathrm{wt} \%$, the slope of the ol liquidus is nearly vertical in $P-T$ space (Pichavant et al. 2002a) (Fig. 14).

The most magnesian spinel composition has a $\mathrm{Fe}^{3+} / \Sigma$ Fe ratio suggesting equilibration at $\Delta \mathrm{NNO}=+1.5-2.0$ (Fig. 13b). These strongly oxidizing conditions are consistent with redox states inferred for the Grenada lavas (Parkinson et al. 2003), and provide further evidence for the existence of oxidized primitive basaltic liquids.

\section{Magmatism in the Lesser Antilles arc}

One important conclusion from this paper is the demonstration that the primitive phenocryst assemblage present in Soufriere lavas crystallized from near-primary parental melts containing $\sim 5 \mathrm{wt} \% \mathrm{H}_{2} \mathrm{O}$. From an estimate of the $\mathrm{H}_{2} \mathrm{O}$ content of the subarc mantle source, Pichavant et al. (2002a) suggested that high-MgO (12.5 wt \%) primary melts may have $\mathrm{H}_{2} \mathrm{O}$ concentrations as high as $5.5 \mathrm{wt} \%$. Therefore, the $\mathrm{H}_{2} \mathrm{O}$ concentration determined here for the primitive Soufriere liquids lies within the range considered possible for Lesser Antilles mantle melts. Since the Soufriere rocks are representative of the primitive group from the southern part of the arc, it is likely that lavas from Grenada, Kick'em Jenny and the Grenadines can have $\mathrm{H}_{2} \mathrm{O}$ contents similar to those determined here for St Vincent. Parental melts with $\sim 5 \mathrm{wt} \% \mathrm{H}_{2} \mathrm{O}$ will differentiate to more water-rich residual melts. For example, since $30-40 \%$ $\mathrm{ol}+\mathrm{cpx}+\mathrm{sp}$ crystallization is necessary to drive the melt from HMB to HAB composition (Fig. 6; see also Sisson and Grove 1993b), HAB-like melts with 7-8 wt $\% \mathrm{H}_{2} \mathrm{O}$ will be generated, if water follows a closed-system, incompatible, behaviour. This range is consistent with melt $\mathrm{H}_{2} \mathrm{O}$ concentrations calculated by applying the $\mathrm{Al}_{2} \mathrm{O}_{3}$ in melt hygrometer to the Soufriere and St. Vincent inclusions (Fig. 9), and with the presence of amphibole as a major phase in the gabbroic cumulates at St Vincent and elsewhere in the arc.

The $\mathrm{H}_{2} \mathrm{O}$-rich nature of the Soufriere parental liquids may seem to be inconsistent with evidence suggesting drier conditions, such as glass inclusion data and high-pressure phase equilibria. For example, Pichavant et al. (2002a) concluded that HMB are extracted relatively dry $\left(\sim 2 \mathrm{wt} \% \mathrm{H}_{2} \mathrm{O}\right)$ from their mantle source, and erupted/emplaced virtually unmodified at the surface. In contrast, this study shows that other HMB liquids are more water-rich. Therefore, primitive basaltic liquids at Soufriere have a range of $\mathrm{H}_{2} \mathrm{O}$ concentrations (2$5 \mathrm{wt} \%)$. Only the driest may erupt unmodified while the more water-rich crystallize and differentiate at depth, producing the more fractionated members of the Soufriere suite. The variability of primary arc magmas in terms of $\mathrm{H}_{2} \mathrm{O}$ contents may reflect temporal and spatial heterogeneities of $\mathrm{H}_{2} \mathrm{O}$ distribution in the mantle wedge. 


\section{Conclusions}

1. Primitive basaltic liquids from the Lesser Antilles arc have been experimentally crystallized at crustal pressures, under oxidizing conditions and in the presence of added water. The experiments simulate the early stages of fractionation in calc-alkaline magma series.

2. In the presence of water, crystallization of olivine and clinopyroxene is promoted, plagioclase crystallization is suppressed. Early spinel crystallization is favoured by the presence of $\mathrm{H}_{2} \mathrm{O}$, but also by high $\mathrm{fO}_{2}$ and high bulk $\mathrm{Cr}$. The earliest stages of fractionation of primitive arc basalts are dominated by crystallization of $\mathrm{ol}+\mathrm{cpx}+\mathrm{sp}$ assemblages. Orthopyroxene crystallization is restricted to $>53 \mathrm{wt} \% \mathrm{SiO}_{2}$ in the coexisting melt, and is suppressed by high melt $\mathrm{H}_{2} \mathrm{O}$ contents and oxidizing $\mathrm{fO}_{2}$.

3. Residual melts from the crystallization of $\mathrm{ol}+\mathrm{cpx}+\mathrm{sp}$ assemblages are depleted in $\mathrm{MgO}$, to a lesser extent in $\mathrm{FeO}_{\mathrm{t}}$, and in $\mathrm{Ol}$ and $\mathrm{Cpx}$ components. They are enriched in $\mathrm{SiO}_{2}$, $\mathrm{Al}_{2} \mathrm{O}_{3}, \mathrm{CaO}$, alkalis and $\mathrm{Qz}$ and Plag components, producing evolved compositions typical of the arc sequence. HAB are generated after $30-40 \%$ crystallization of $\mathrm{HMB}$, stressing the existence of a genetic link between high-Al and high-Mg basaltic magmas in the Lesser Antilles and other arcs.

4. The role of $\mathrm{H}_{2} \mathrm{O}$ in depressing plagioclase crystallization leads to a direct relation between the $\mathrm{Al}_{2} \mathrm{O}_{3}$ content of the residual melt and its $\mathrm{H}_{2} \mathrm{O}$ concentration. The $\mathrm{Al}_{2} \mathrm{O}_{3}$ content of natural basaltic liquids can be used as a geohygrometer.

5. Phenocrysts in the Soufriere suite include a primitive assemblage with ol $\left(\mathrm{Fo}_{89.6}\right)$, cpx $(\mathrm{Mg} \#=90)$ and $\mathrm{Cr}-\mathrm{Al} \mathrm{sp}(\mathrm{Mg} \#=53, \mathrm{Cr}=51)$. The presence of ol and cpx with typical mantle compositions links magma generation/equilibration in the mantle and the early crystallization history. Hornblende plays no role in the early petrogenetic evolution.

6. The most magnesian phenocrysts in the Soufriere suite crystallized from near-primary $(\mathrm{Mg} \#=73.5)$, hydrous $\left(5 \mathrm{wt} \% \mathrm{H}_{2} \mathrm{O}\right)$ and very oxidized $(\triangle \mathrm{NNO}=+1.5-2.0) \mathrm{HMB}$ liquids at middle crustal pressures and temperatures from $\sim 1,160$ to $\sim 1,060^{\circ} \mathrm{C}$. These liquids were parental to $\mathrm{HAB}$ melts containing 7-8 wt \% dissolved $\mathrm{H}_{2} \mathrm{O}$.

7. At Soufriere, the primitive basaltic liquids have a range of $\mathrm{H}_{2} \mathrm{O}$ concentrations $(2-5 \mathrm{wt} \%)$. Only the driest erupt whilst the more water-rich crystallize and differentiate at depth.

\section{Acknowledgments}

Financially supported by the Natural Environment Research Council (UK) and the DYETI and ANR programs (France). We thank A.-S. Bouvier for her unpublished glass inclusion analyses. Constructive reviews and comments by O. Müntener and P. Ulmer and the editorial suggestions of T. Grove considerably improved the presentation of this study. 


\section{References}

Albarède F (1995) Introduction to geochemical modelling. Cambridge University Press, Cambridge, p 543

Arculus RJ (1976) Geology and geochemistry of the alkali basalt-andesite association of Grenada, Lesser Antilles island arc. Bull Soc Geol Am 87:612-624

Arculus RJ (1978) Mineralogy and petrology of Grenada, Lesser Antilles island arc. Contrib Mineral Petrol 65:413-424

Arculus RJ (1994) Aspects of magma genesis in arcs. Lithos 33:189-208

Arculus RJ, Wills KJA (1980) The petrology of plutonic blocks and inclusions from the Lesser Antilles island arc. J Petrol 21:743-799

Baker MB, Grove TL, Price R (1994) Primitive basalts and andesites from the Mt Shasta region, N California: products of varying melt fraction and water content. Contrib Mineral Petrol 118:111-129

Ballhaus C, Berry RF, Green DH (1991) High pressure experimental calibration of the olivine-orthopyroxene-spinel oxygen geobarometer: implications for the oxidation state of the upper mantle. Contrib Mineral Petrol 107:27-40

Barclay J, Carmichael ISE (2004) A hornblende basalt from western Mexico: water-saturated phase relations constrain a pressure-temperature window of eruptibility. J Petrol 45:485-506

Barclay J, Rutherford MJ, Carroll MR (1998) Experimental phase equilibria constraints on pre-eruptive storage conditions of the Soufriere Hills magma. Geophys Res Lett 25:34373440

Bardintzeff JM (1983) Les verres et les magmas de l'éruption de 1979 de la Soufrière de Saint-Vincent (Antilles). Bull Soc Gèol Fr XXV(7):811-818

Bartels KS, Kinzler RJ, Grove TL (1991) High pressure phase relations of primitive highalumina basalts from Medicine Lake volcano, northern California. Contrib Mineral Petrol 108:253-270

Brandon AD, Draper DS (1996) Constraints on the origin of the oxidation state of mantle overlying subduction zones: an example from Simcoe, Washington, USA. Geochim Cosmochim Acta 60:1739-1749

Brophy JG (1989) Can high-alumina arc basalt be derived from low-alumina arc basalt ? Evidence from Kanaga island, Aleutian arc, Alaska. Geology 17:333-336

Burnham CW (1979) The importance of volatile constituents. In: Yoder HS (ed) The Evolution of Igneous Rocks. Princeton University Press, pp 439-482

Cawthorn RG, Curran EB, Arculus RJ (1973) A petrogenetic model for the origin of the calcalkaline suite of Grenada, Lesser Antilles. J Petrol 14:327-337 
Costa F, Scaillet B, Pichavant M (2004) Petrological and experimental constraints on the preeruption conditions of Holocene dacite from Volcán San Pedro $\left(36^{\circ} \mathrm{S}\right.$, Chilean Andes) and the importance of sulphur in silicic subduction-related magmas. J Petrol 45:855-881

Crawford AJ, Falloon TJ, Eggins S (1987) The origin of island arc high-alumina basalts. Contrib Mineral Petrol 97:417-430

Devine JD, Sigurdsson H (1983) The liquid composition and crystallization history of the 1979 Soufriere magma, St Vincent, WI. J Volcanol Geotherm Res 16:1-31

Devine JD, Sigurdsson H (1995) Petrology and eruption styles of Kick'em-Jenny submarine volcano, Lesser Antilles island arc. J Volcanol Geotherm Res 69:35-58

Devine, JD, Gardner JE, Brack HP, Layne GD, Rutherford MJ (1995) Comparison of microanalytical methods for estimating $\mathrm{H}_{2} \mathrm{O}$ contents of silicic volcanic glasses. Am Mineral $80: 319-328$

Di Carlo I, Pichavant M, Rotolo S, Scaillet B (2006) Experimental crystallization of a high-K arc basalt: the golden pumice, Stromboli volcano (Italy). J Petrol 47:1317-1343

Draper DS, Johnston AD (1992) Anhydrous PT phase relations of an Aleutian high-MgO basalt: an investigation of the role of olivine-liquid reaction in the generation of arc highalumina basalts. Contrib Mineral Petrol 112:501-519

Eggins SM (1993) Origin and differentiation of picritic arc magmas, Ambae (Aoba), Vanuatu. Contrib Mineral Petrol 114:79-100

Gaetani GA, Grove TL (1998) The influence of water on the melting of mantle peridotite. Contrib Mineral Petrol 131:323-346

Gaetani GA, Grove TL, Bryan WB (1993) The influence of water on the petrogenesis of subduction-related igneous rocks. Nature 365:332-334

Gaetani GA, Grove TL, Bryan WB (1994) 32. Experimental phase relations of basaltic andesite from hole 839B under hydrous and anhydrous conditions. Proceedings of the Ocean Drilling Program, Scientific Results 135:557-563

Gill JB (1981) Orogenic andesites and plate tectonics. Springer, Heidelberg

Graham AM (1981) Melting relations of island arc lavas from Grenada, Lesser Antilles. In: Ford CE (ed) Progress in experimental petrology, NERC Publications Series D, pp 126-132

Graham AM, Thirlwall MF (1981) Petrology of the 1979 eruption of Soufriere volcano, St Vincent, Lesser Antilles. Contrib Mineral Petrol 76:336-342

Grove TL, Baker MB (1984) Phase equilibrium controls on tholeiitic versus calc-alkaline differentiation trends. J Geophys Res 89:3252-3274 
Grove TL, Elkins-Tanton LT, Parman SW, Chatterjee N, Müntener O, Gaetani GA (2003) Fractional crystallization and mantle-melting controls on calc-alkaline differentiation trends. Contrib Mineral Petrol 145:515-533

Gust DA, Perfit MR (1987) Phase relations of a high-Mg basalt from the Aleutian Island Arc: Implications for primary island arc basalts and high-Al basalts. Contrib Mineral Petrol 97:718

Heath E, Macdonald R, Belkin HE, Hawkesworth CJ, Sigurdsson H (1998) Magmagenesis at Soufriere volcano, St Vincent, Lesser Antilles arc. J Petrol 39:1721-1764

Holloway JR (1987) Igneous fluids. In: Eugster HP, Carmichael ISE (eds) Thermodynamic modelling of geological materials: minerals, fluids and melts. Mineralogical Society of America, Reviews in Mineralogy 17, pp 211-233

Holloway JR, Burnham CW (1972) Melting relations of basalt with equilibrium water pressure less than total pressure. J Petrol 13:1-29

Kress V, Carmichael ISE (1991) The compressibility of silicate liquids containing Fe2O3 and the effect of composition, temperature, oxygen fugacity and pressure on their redox states. Contrib Mineral Petrol 108 82:92

Lesne P (2004) Les conditions pré-éruptives d'un liquide basique de la Soufrière, Guadeloupe. DEA, University of Orléans, p 46

Lewis JF (1973a) Petrology of the ejected plutonic blocks of the Soufriere volcano, St Vincent, West Indies. J Petrol 14:81-112

Lewis JF (1973b) Mineralogy of the ejected plutonic blocks of the Soufriere volcano, St Vincent: olivine, pyroxene, amphibole and magnetite paragenesis. Contrib Mineral Petrol 38:197-220

Lindsley DH (1983) Pyroxene thermometry. Am Mineral 68:477-493

Macdonald R, Hawkesworth CJ, Heath E (2000) The Lesser Antilles volcanic chain: a study in arc magmatism. Earth Sci Rev 49:1-76

Marcelot G, Le Guen de Kerneizon M, Bohn M (1981) Zonation du nickel et du chrome dans les minéraux ferromagnésiens d'un basalte de Saint-Vincent (Petites Antilles); conséquences pétrogénétiques. CR Acad Sci Paris 293:1079-1081

Martel C, Pichavant M, Bourdier J-L, Traineau H, Holtz F, Scaillet B (1998) Magma storage conditions and control of eruption regime in silicic volcanoes: experimental evidence from Mt. Pelée. Earth Planet Sci Lett 156:89-99

Martel C, Pichavant M, Holtz F, Scaillet B, Bourdier J-L, Traineau H (1999) Effects of $\mathrm{fO}_{2}$ and $\mathrm{H}_{2} \mathrm{O}$ on andesite phase relations between 2 and 4 kbar. J Geophys Res 104:29453-29470

Miyashiro A (1974) Volcanic rock series in island arcs and active continental margins. Am J Sci 275:321-355 
Müntener O, Kelemen P, Grove TL (2001) The role of $\mathrm{H}_{2} \mathrm{O}$ during crystallization of primitive arc magmas under uppermost mantle conditions and genesis of igneous pyroxenites: an experimental study. Contrib Mineral Petrol 141:643-658

Nye CJ, Reid MR (1986) Geochemistry of primary and least fractionated lavas from Okmok volcano, central Aleutians: implications for arc magmagenesis. J Geophys Res 91:1027110287

Parkinson IJ, Arculus RJ, Eggins SM (2003) Peridotite xenoliths from Grenada, Lesser Antilles island arc. Contrib Mineral Petrol 146:241-262

Pichavant M, Macdonald R (2003) Mantle genesis and crustal evolution of primitive calcalkaline basaltic magmas from the Lesser Antilles arc. In: Larter RD, Leat PT (eds) Intraoceanic subduction systems: tectonic and magmatic processes. Special Publications 219, The Geological Society, London, pp 239-254

Pichavant M, Mysen BO, Macdonald R (2002a) Source and $\mathrm{H}_{2} \mathrm{O}$ content of high-MgO magmas in island arc settings: an experimental study of a primitive calc-alkaline basalt from St. Vincent, Lesser Antilles arc. Geochim Cosmochim Acta 66:2193-2209

Pichavant M, Martel C, Bourdier J-L, Scaillet B (2002b) Physical conditions, structure and dynamics of a zoned magma chamber: Mount Pelée (Martinique, Lesser Antilles arc). J Geophys Res 107:ECV 2 1-ECV30. doi:10.1029/2001JB000315

Poussineau S (2005) Dynamique des magmas andésitiques: approche expérimentale et pétrostructurale; application à la Soufrière de Guadeloupe et à la Montagne Pelée. $\mathrm{PhD}$ thesis, University of Orléans, p 295

Pownceby MI, O’Neill HStC (1994) Thermodynamic data from redox reactions at high temperatures. III. Activity-composition relations in Ni-Pd alloys from EMF measurements at $850-1250 \mathrm{~K}$ and calibration of the $\mathrm{NiO}+\mathrm{Ni}-\mathrm{Pd}$ assemblage as a redox sensor. Contrib Mineral Petrol 116:327-339

Prouteau G, Scaillet B (2003) Experimental constraints on the origin of the 1991 Pinatubo dacite. J Petrol 44:2203-2241

Robie RA, Hemingway BS, Fisher JR (1979) Thermodynamic properties of minerals and related substances at $298.15 \mathrm{~K}$ and 1 bar $\left(10^{5}\right.$ pascals $)$ pressure and at higher temperatures. US Geol Surv Bull 1452

Roggensack K (2001) Unraveling the 1974 eruption of Fuego volcano (Guatemala) with small crystals and their young melt inclusions. Geology 29:911-914

Roggensack K, Hervig RL, McKnight SB, Williams SN (1997) Explosive basaltic volcanism from Cerro Negro volcano: influence of volatiles on eruptive style. Science 277:1639-1642

Rohrbach A, Schuth S, Ballhaus C, Münker C, Matveev S, Qopoto C (2005) Petrological constraints on the origin of arc picrites, New Georgia group, Solomon islands. Contrib 
Mineral Petrol 149:685-698

Roux J, Lefèvre A (1992) A fast quench device for IHPV. Eur J Mineral 4:279-281

Roux J, Holtz F, Lefèvre A, Schulze F (1994) A reliable high temperature setup for internally heated pressure vessel: applications to silicate melt studies. Am Mineral 79:1145-1149

Rutherford MJ, Devine JD (2003) Magmatic conditions and magma ascent as indicated by hornblende phase equilibria and reactions in the 1995-2002 Soufriere Hills magma. J Petrol $44: 1433-1454$

Scaillet B, Evans BW (1999) The June 151991 eruption of Mount Pinatubo. 1. Phase equilibria and pre-eruption P-T-fO2-fH2O conditions of the dacite magma. J Petrol 40:381411

Scaillet B, Pichavant M, Roux J, Humbert G, Lefèvre A (1992) Improvements of the Shaw membrane technique for measurement and control of $\mathrm{fH} 2$ at high temperatures and pressure. Am Mineral 77:647-655

Scaillet B, Pichavant M, Roux J (1995) Experimental crystallization of leucogranite magmas. J Petrol 36:663-705

Schiano P, Clocchiatti R, Boivin P, Médard E (2004) The nature of melt inclusions inside minerals in an ultramafic cumulate from Adak volcanic enter, Aleutian arc: implications for the origin of high-alumina basalts. Chem Geol 203:169-179

Sisson TW, Grove TL (1993a) Experimental investigations of the role of $\mathrm{H}_{2} \mathrm{O}$ in calc-alkaline differentiation and subduction zone magmatism. Contrib Mineral Petrol 113:143-166

Sisson TW, Grove TL (1993b) Temperatures and $\mathrm{H}_{2} \mathrm{O}$ contents of low-MgO high alumina basalts. Contrib Mineral Petrol 113:167-184

Smith TE, Thirlwall MF, MacPherson C (1996) Trace-element and isotope geochemistry of the volcanic rocks of Bequia, Grenadine islands, Lesser Antilles arc: a study of subduction enrichment processes. J Petrol 37:117-143

Tatsumi Y, Sakuyama M, Fukuyama H, Kushiro I (1983) Generation of arc basalt magmas and thermal structure of the mantle wedge in subduction zones. J Geophys Res 88:5815-5825

Taylor JR, Wall VJ, Pownceby MI (1992) The calibration and application of accurate redox sensors. Am Mineral 77:284-295

Tormey DR, Grove TL, Bryan WB (1987) Experimental petrology of normal MORB near the Kane fracture zone: $22^{\circ}-25^{\circ} \mathrm{N}$, mid-Atlantic ridge. Contrib Mineral Petrol 96:121-139

Ulmer P (1989) The dependence of the $\mathrm{Fe}^{2+}-\mathrm{Mg}$ cation-partitioning between olivine and basaltic liquid on pressure, temperature and composition. Contrib Mineral Petrol 101:261-273 
Westercamp D (1988) Magma generation in the Lesser Antilles: geological constraints. Tectonophys 149:145-163

Westercamp D, Mervoyer B (1976) Les séries volcaniques de la Martinique. Bull BRGM 2IV:231-242

Yoder HS Jr (1965) Diopside-anorthite-water at five and ten kilobars and its bearing on explosive volcanism. Yearb Carnegie Inst Wash 64:82-89

Zellmer GF, Hawkesworth CJ, Sparks RSJ, Thomas LE, Harford CL, Brewer TS, Loughlin SC (2003) Geochemical evolution of the Soufriere Hills volcano, Lesser Antilles volcanic arc. J Petrol 44:1349-1374 


\section{Figures}
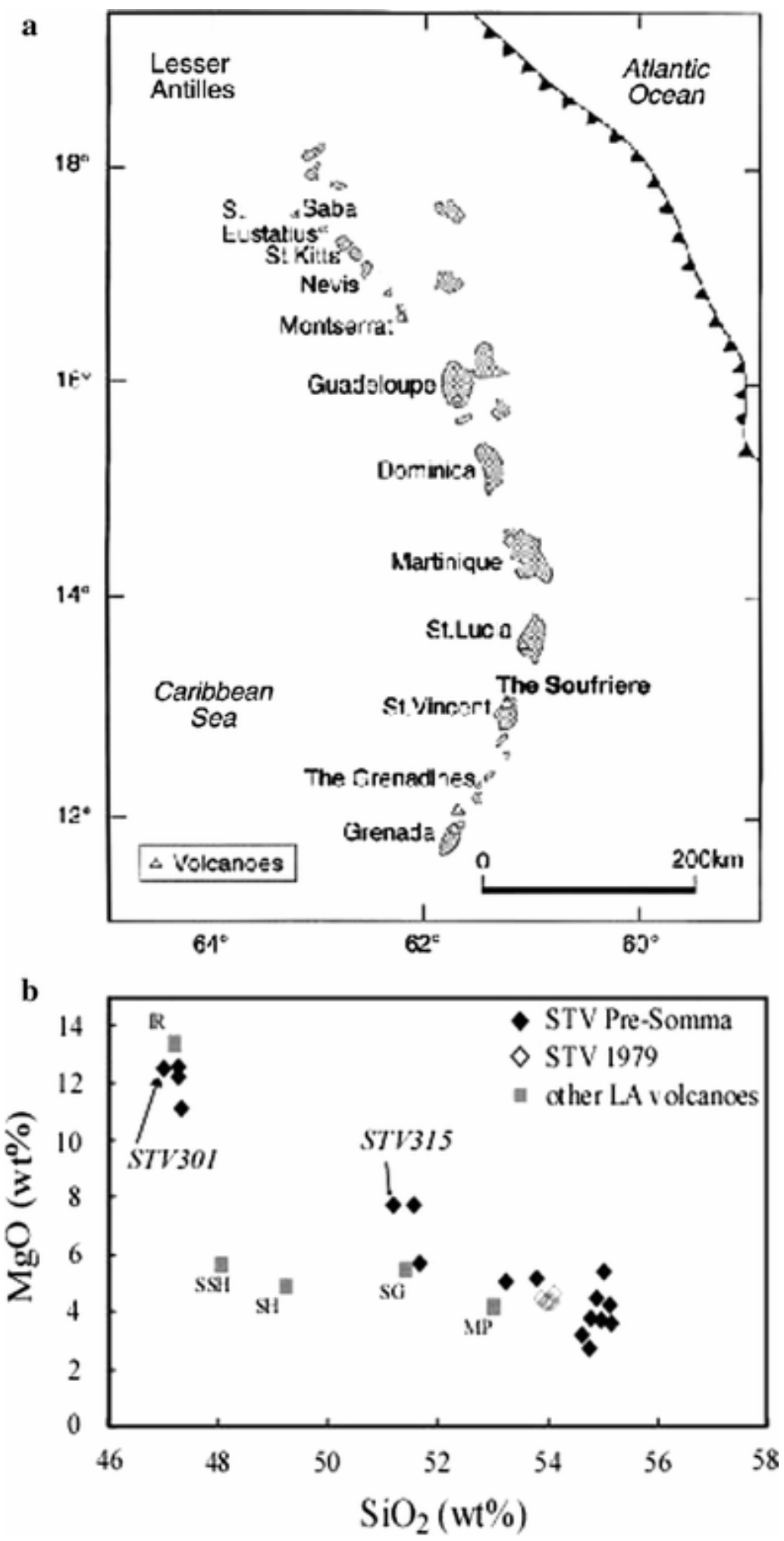

Fig. 1 a Map of the Lesser Antilles arc showing the main islands and active volcanoes, after Heath et al. (1998). b Variation diagram showing compositions of selected mafic lavas from St Vincent and other volcanoes from the arc. STV Soufriere, St Vincent (Pre-Somma lavas: Heath et al. 1998; 1979 lavas: Graham and Thirlwall 1981); IR Ilet à Ramiers, Martinique (Westercamp and Mervoyer 1976); SSH and SH, respectively, South Soufriere Hills and Soufriere Hills, Montserrat (Zellmer et al. 2003); S 


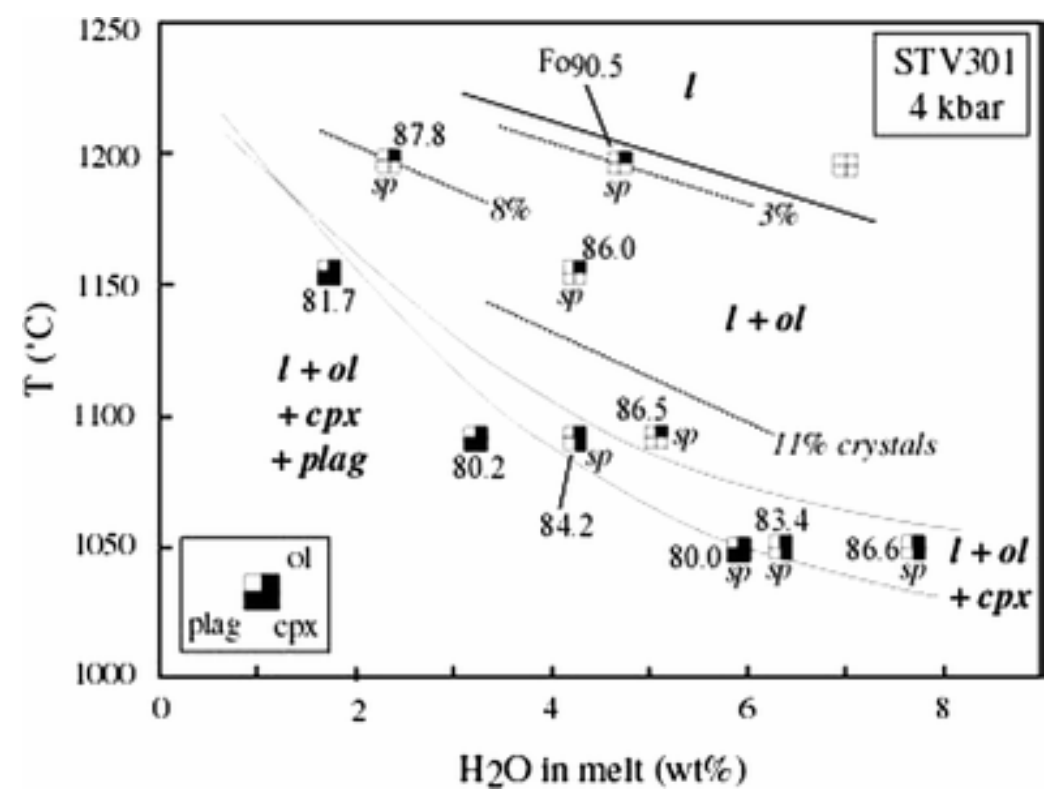

Fig. 2 Near-liquidus 4 kbar $\mathrm{T}-\mathrm{H}_{2} \mathrm{O}$ in melt phase diagram for high-MgO basalt STV301 showing experimental data points, saturation curves and stability fields. I liquid (silicate melt); ol olivine; cpx clinopyroxene; plag plagioclase; $s p \mathrm{Cr}-\mathrm{Al}$ spinel. Presence of spinel indicated by sp adjacent to the data points. The proportion ( 3,8 , $11 \mathrm{wt} \%$ ) of crystals present in the $1+$ ol field is contoured. Data points are labelled with the Fo content of olivine. All data in Tables 3 and 4

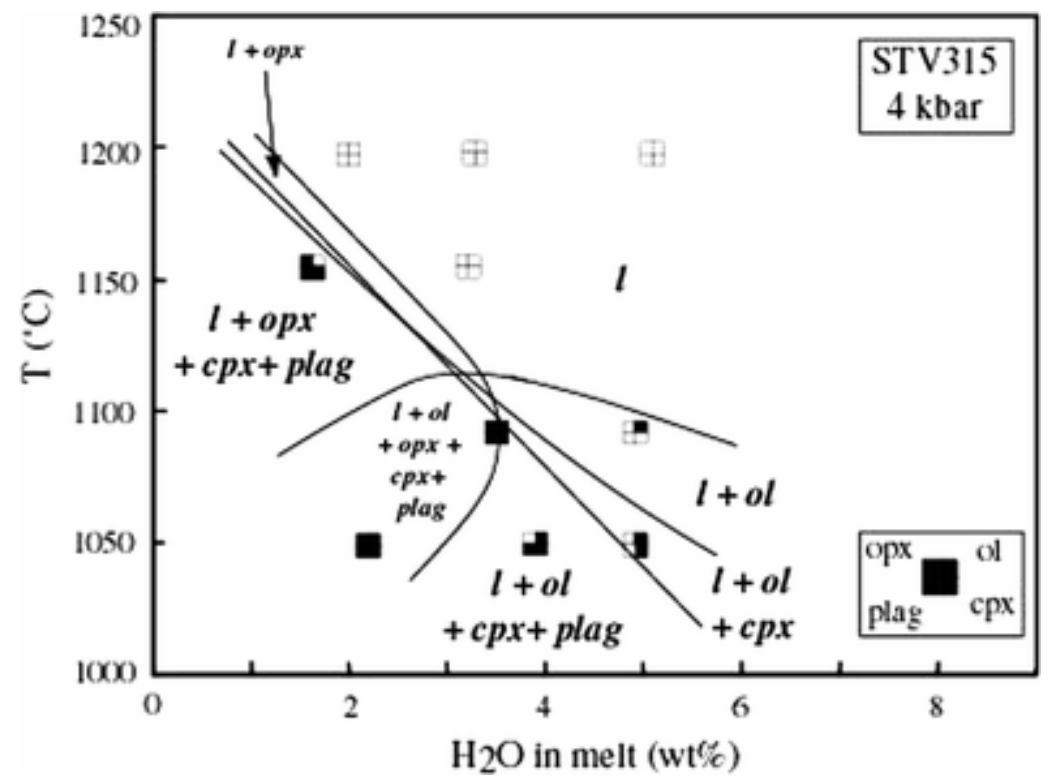

Fig. 3 Near-liquidus 4 kbar T- $\mathrm{H}_{2} \mathrm{O}$ in melt phase diagram for basalt STV315 showing experimental data points, saturation curves and stability fields. Opx orthopyroxene, other abbreviations as in Fig. 2. All data in Table 3 


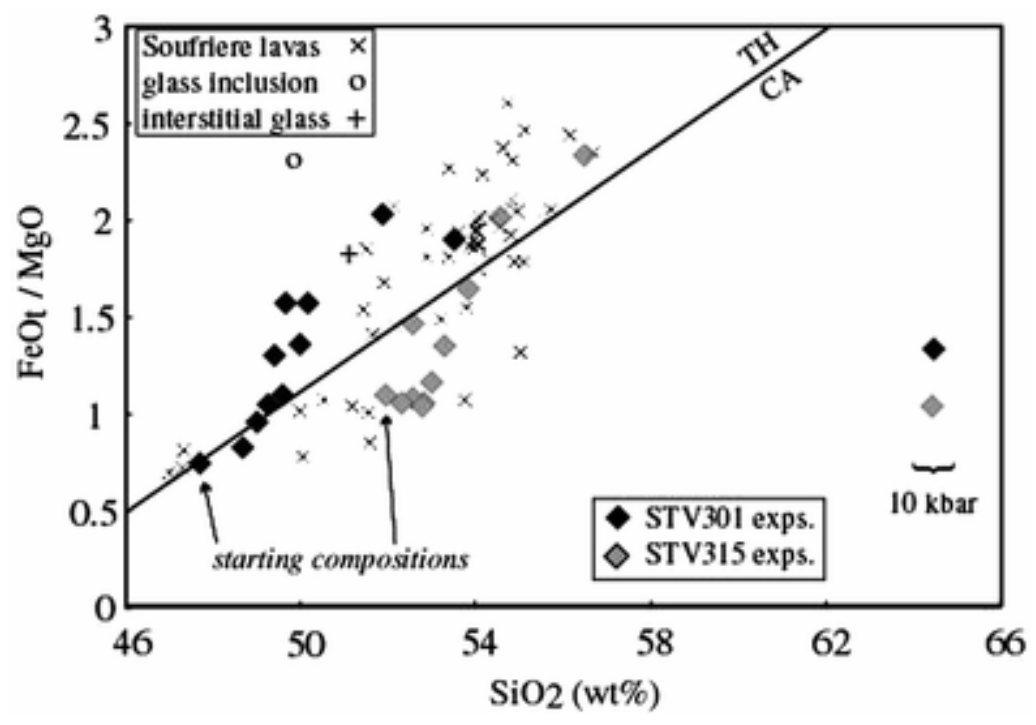

Fig. 4 Plot of $\mathrm{FeO}_{\mathrm{t}} / \mathrm{MgO}$ versus $\mathrm{SiO}_{2}$ (Miyashiro 1974) for experimental glasses (this study) and Soufriere natural products. Lava whole-rock compositions from Graham and Thirlwall (1981) and Heath et al. (1998). Glass inclusion represents the average of melt inclusions in olivine from the 1979 eruption (Devine and Sigurdsson 1983). Interstitial glass represents the composition of an interstitial scoria from a gabbroic cumulate (Lewis 1973a). Experimental data at 4 kbar except otherwise stated (10 kbar)

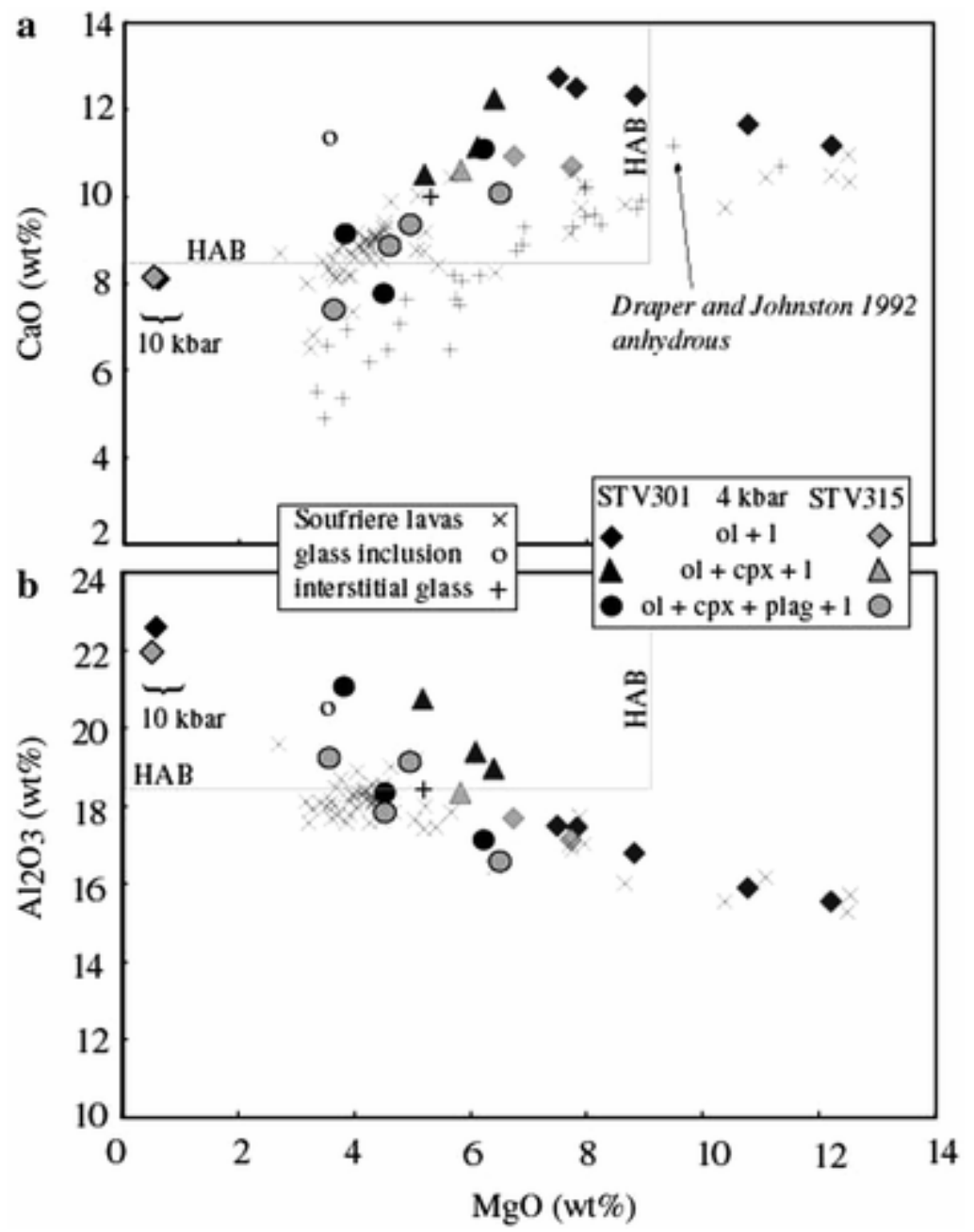

Fig. $5 \mathrm{MgO}$ variation diagrams $\left(\mathbf{a ~ C a O} ; \mathbf{b ~} \mathrm{Al}_{2} \mathrm{O}_{3}\right)$ for experimental glasses (this study) and Soufriere natural products (Fig. 4). Experimental data at 4 kbar except otherwise stated (10 kbar). Data points separated by phase assemblage, with starting glasses and ol +1 charges plotted under the same symbol. For STV315, all cpx + plag- 
bearing charges, either ol-bearing, ol-free or opx-bearing are plotted under the same symbol. In (a), the experimental glasses from the anhydrous high-pressure experiments of Draper and Johnston (1992) are shown for comparison with the hydrous trends from this study. The HAB (high-alumina basalt) boxes are constructed from the compositional criteria suggested by Draper and Johnston (1992). Abbreviations as in Fig. 2

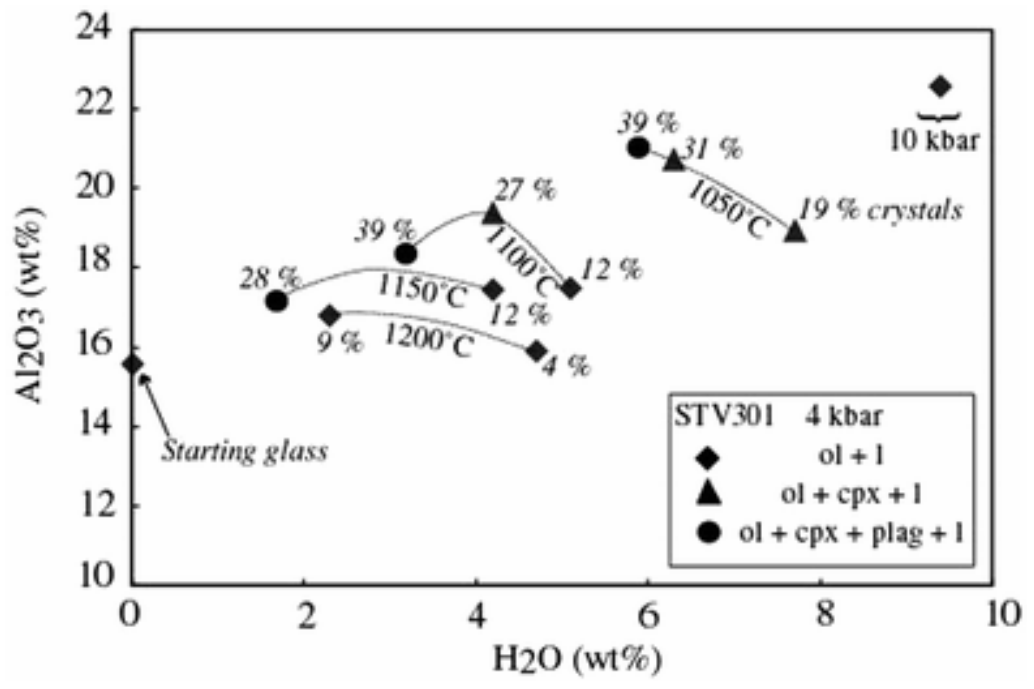

Fig. $6 \mathrm{Al}_{2} \mathrm{O}_{3}$ contents of experimental liquids as a function of their melt $\mathrm{H}_{2} \mathrm{O}$ content. Experimental data for STV301 only and at 4 kbar except otherwise stated (10 kbar). Data points separated by phase assemblage, as in Fig. 5, and labelled with proportions of crystals in the charges (wt\%, Table 3). Abbreviations as in Fig. 2

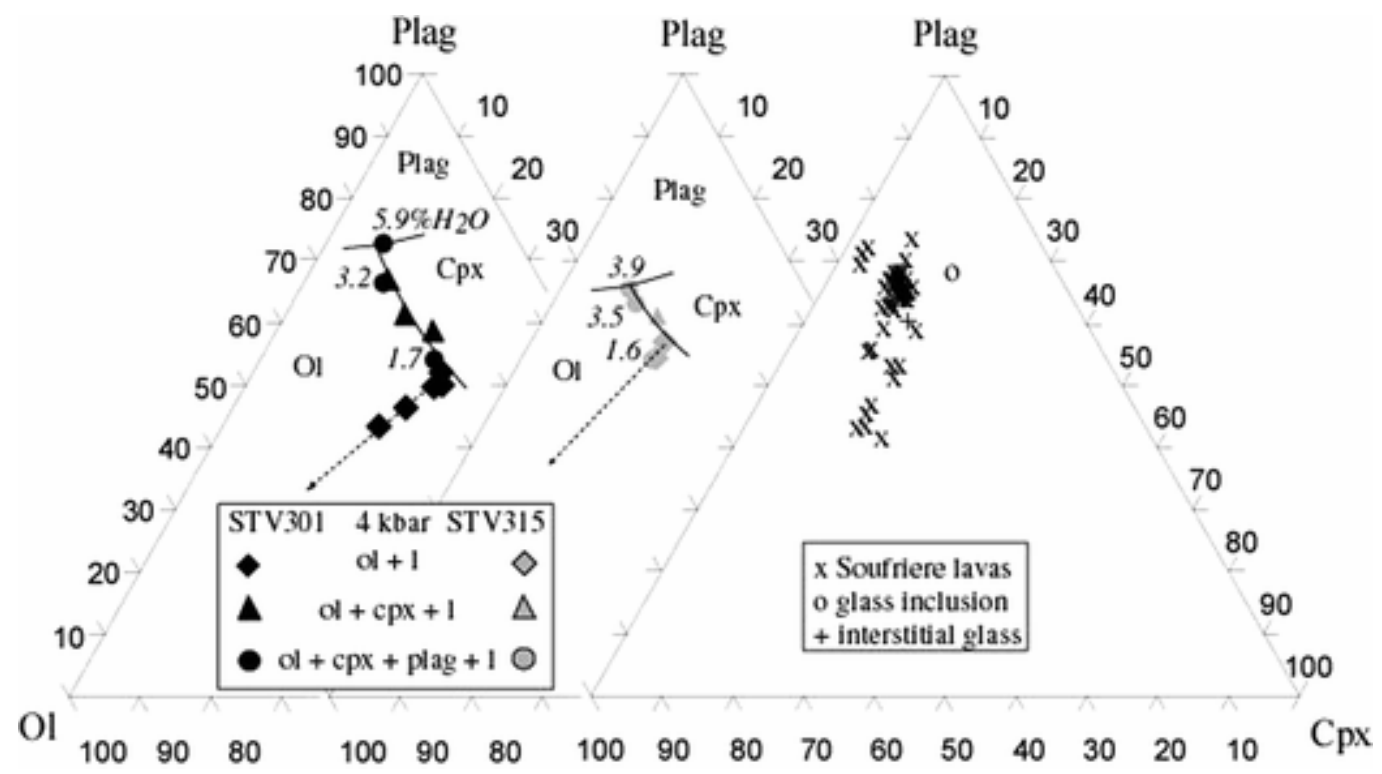

Fig. 7 Pseudo-ternary Ol-Plag-Cpx diagrams showing compositions of experimental glasses (STV301: left diagram; STV315: middle diagram) and Soufriere natural products (right diagram, significance of data points as in Fig. 4). Projection scheme of Tormey et al (1987). Data points separated by phase assemblage, as in Fig. 5. $\mathrm{Ol}+\mathrm{cpx}+$ plag +1 data points labelled with melt $\mathrm{H}_{2} \mathrm{O}$ concentrations (see text). Stability field and field boundaries (curved lines) are indicated. Dashed lines are olivine control lines. Corundum-normative glasses 1-5, 1-9 (10 kbar charges) and glass 4-6 (see text) are not shown. For clarity, the supraliquidus glasses 6-4, 7-4, 7-5, 7-6 (STV315) have not been plotted. Abbreviations as in Fig. 2 


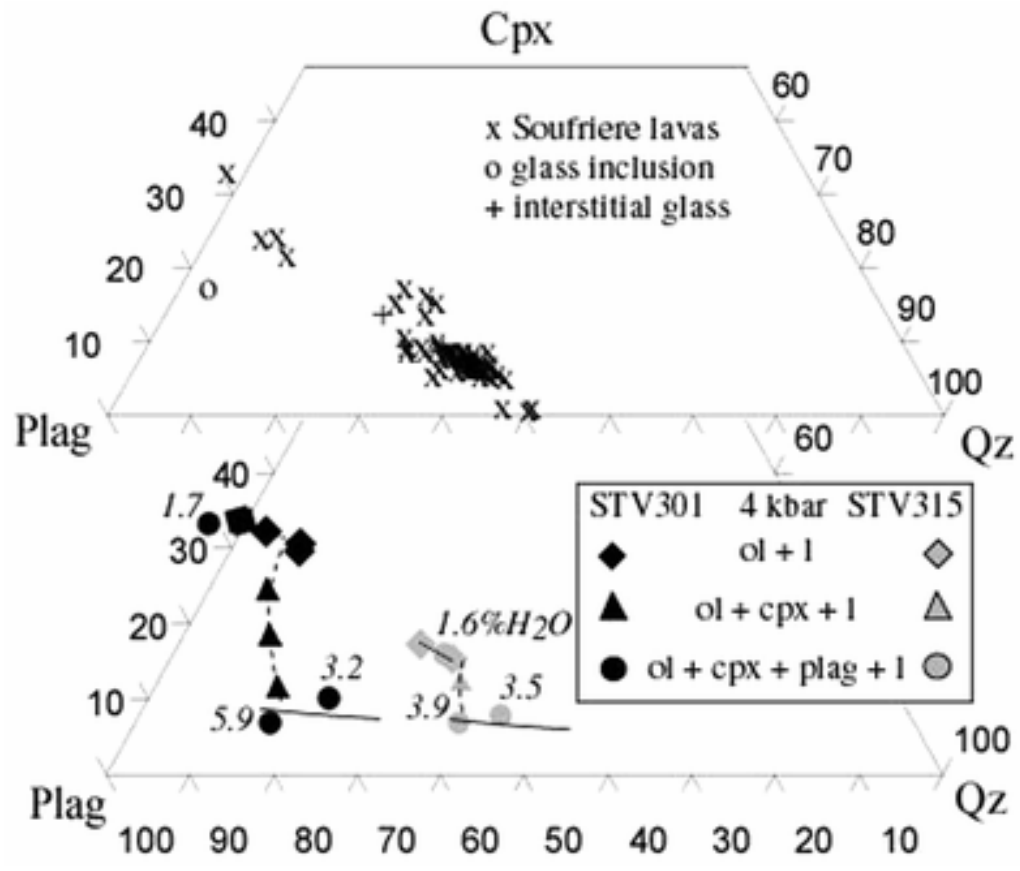

Fig. 8 Pseudo-ternary Plag-Cpx-Qz diagrams showing compositions of experimental glasses (lower diagram) and Soufriere natural products (upper diagram, significance of data points as in Fig. 4). Projection scheme of Tormey et al. (1987). Data points separated by phase assemblage, as in Fig. 5 . Ol + cpx + plag +1 data points labelled with melt $\mathrm{H}_{2} \mathrm{O}$ concentrations (see text). Liquid paths for ol (dotted), ol + cpx (dashed) and $\mathrm{ol}+\mathrm{cpx}+$ plag $+/$ - opx (solid lines) fractionating assemblages are outlined. Corundum-normative glasses 1-5, 19 (10 kbar charges) and glass 4-6 (see text) are not shown. For clarity, the supraliquidus glasses 6-4, 7-4, 7-5, 7-6 (STV315) have not been plotted. Abbreviations as in Fig. 2

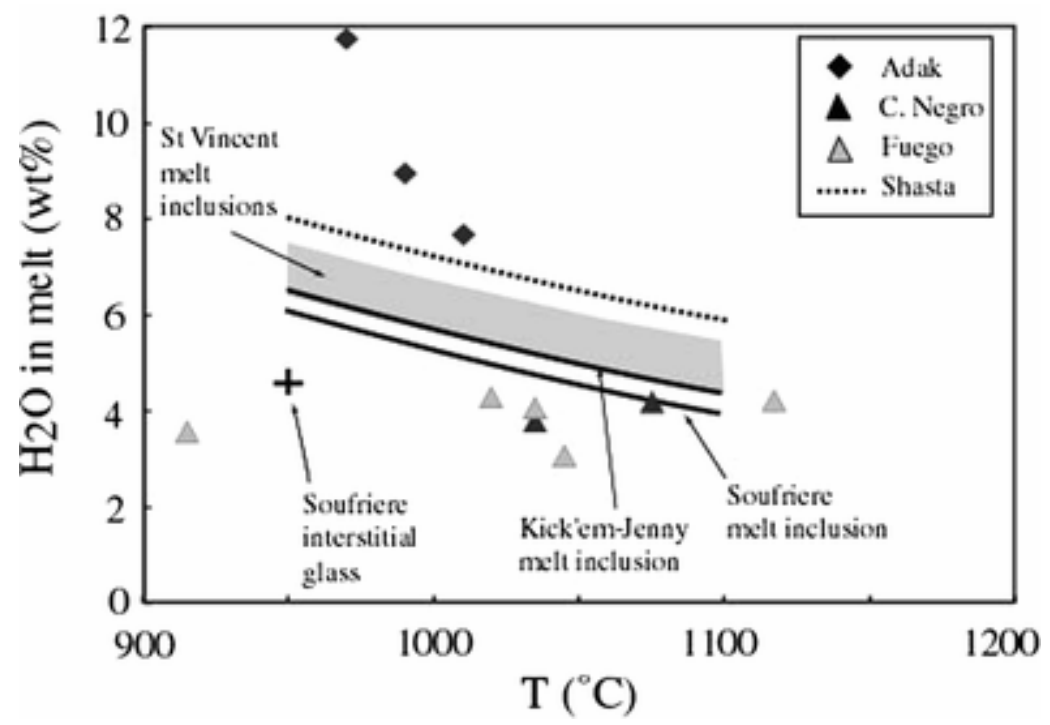

Fig. 9 Calculated melt $\mathrm{H}_{2} \mathrm{O}$ contents and temperatures for selected arc basaltic liquids. The calculations use the geohygrometer described in text and Table 5. Input data for the calculations are major element compositions of melt inclusion except for one interstitial glass from a Soufriere gabbroic cumulate. When no constraints are available on temperature, melt $\mathrm{H}_{2} \mathrm{O}$ concentrations are calculated between 950 and $1,100^{\circ} \mathrm{C}$ (solid and dashed curves, grey field). For the interstitial glass, a temperature of $950^{\circ} \mathrm{C}$ is assumed. In other cases, the geohygrometer computes either $\mathrm{H}_{2} \mathrm{O}$ in melt when temperature is available (Adak) or temperature when the melt $\mathrm{H}_{2} \mathrm{O}$ content is known (Cerro Negro, Fuego). Compositions of the Soufriere interstitial glass from Lewis (1973a) and of the Soufriere inclusion from Devine and Sigurdsson (1983). Compositions of other melt inclusions: St Vincent (Bouvier et al. written communication, 2006), Kick'em-Jenny (Devine and Sigurdsson 1995), Adak 
(Schiano et al. 2004), Cerro Negro (Roggensack et al. 1997), Fuego (Roggensack 2001), Shasta (Sisson and Grove 1993b)

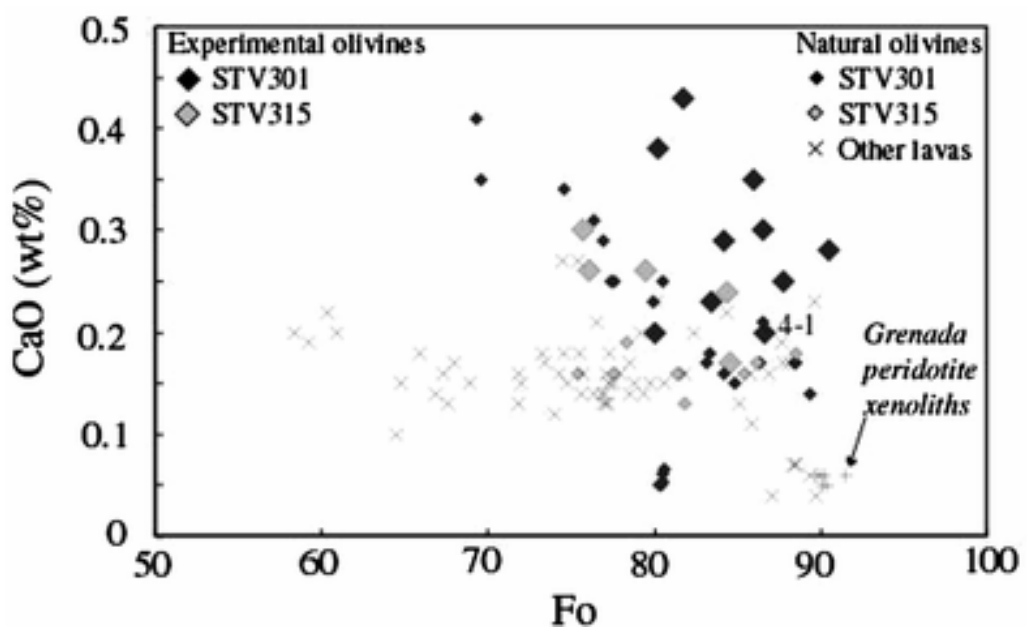

Fig. $10 \mathrm{CaO}$ in experimental (this study) and natural (Marcelot et al. 1981; Heath et al. 1998) olivines plotted as a function of their forsterite (Fo) content. Compositions of olivines in peridotite xenoliths from Grenada after Parkinson et al. (2003). Olivine composition in charge 4-1 (discussed in text) is indicated

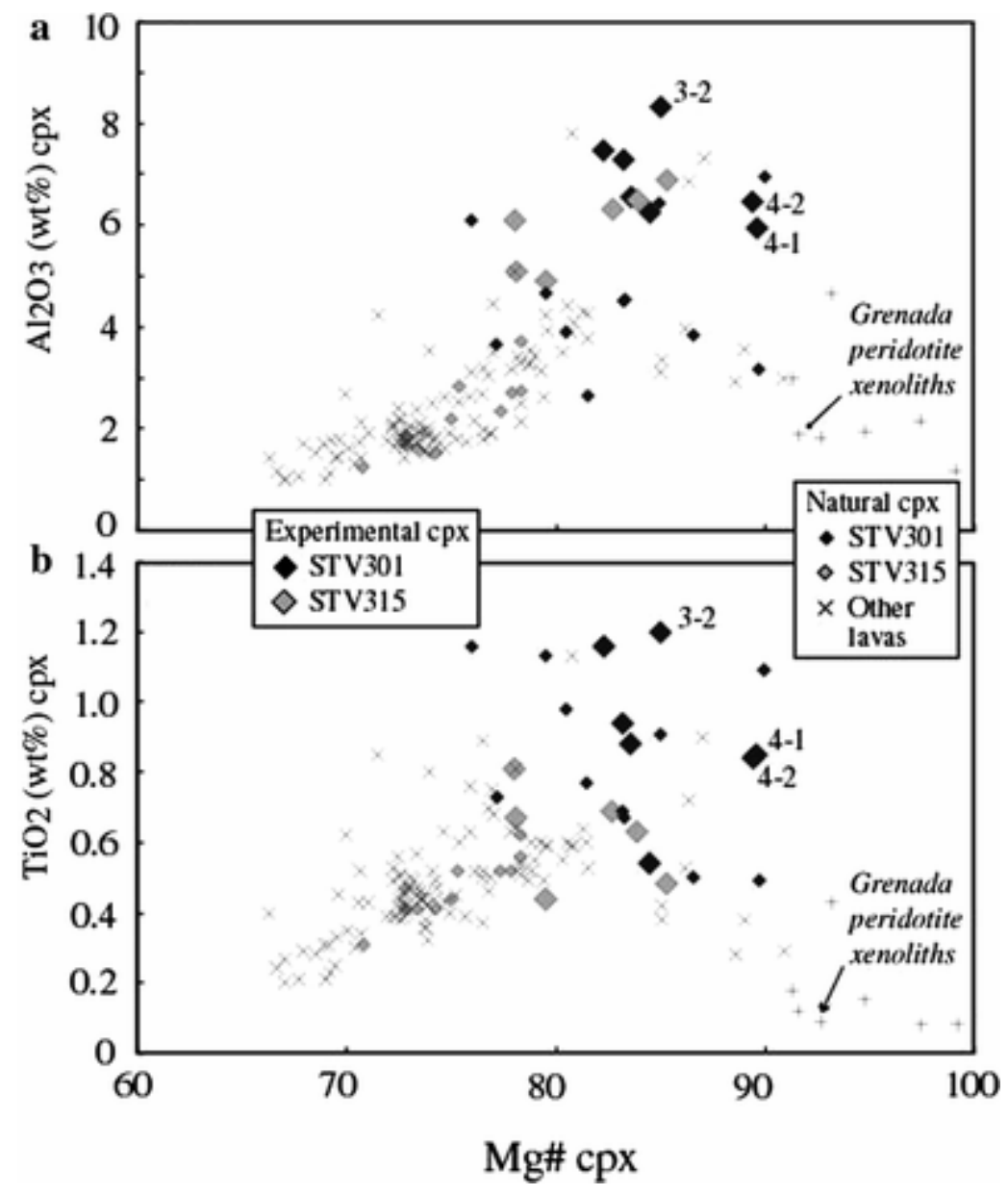

Fig. $11 \mathrm{Al}_{2} \mathrm{O}_{3}$ (a) and $\mathrm{TiO}_{2}$ (b) in experimental (this study) and natural (Graham and Thirlwall 1981; Marcelot et al. 1981; Heath et al. 1998) clinopyroxenes plotted as a function of their $\mathrm{Mg}$, calculated with $\mathrm{Fe}=\mathrm{Fe}^{2+}$. Compositions of cpx in peridotite xenoliths from Grenada after Parkinson et al. (2003). Cpx compositions in charges 4-1, 4-2 and 3-2 (discussed in text) are indicated 


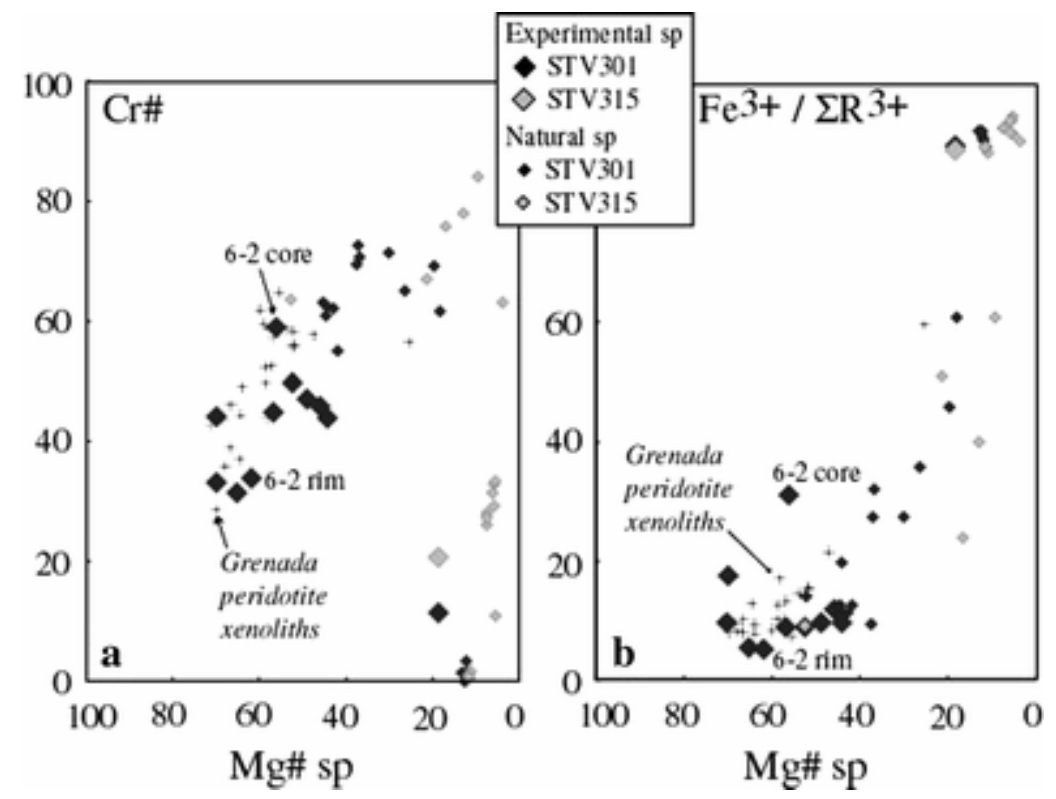

Fig. $12 \mathrm{Cr} \#$ (a) and $\mathrm{Fe}^{3+} / \Sigma \mathrm{R}^{3+}$ (b) in experimental (this study) and natural (Marcelot et al. 1981; Heath et al. 1998) spinels as a function of their Mg\#. Cr-Al spinels and magnetite plotted with the same symbol. Compositions of spinel in peridotite xenoliths from Grenada after Parkinson et al. (2003). Core and rim indicate compositions of the partially reacted spinel grain in charge 6-2 (see text). For charges 4-1, 4-2, 4-3, 3-1, 3-2, the corrected spinel compositions are plotted (see text) 

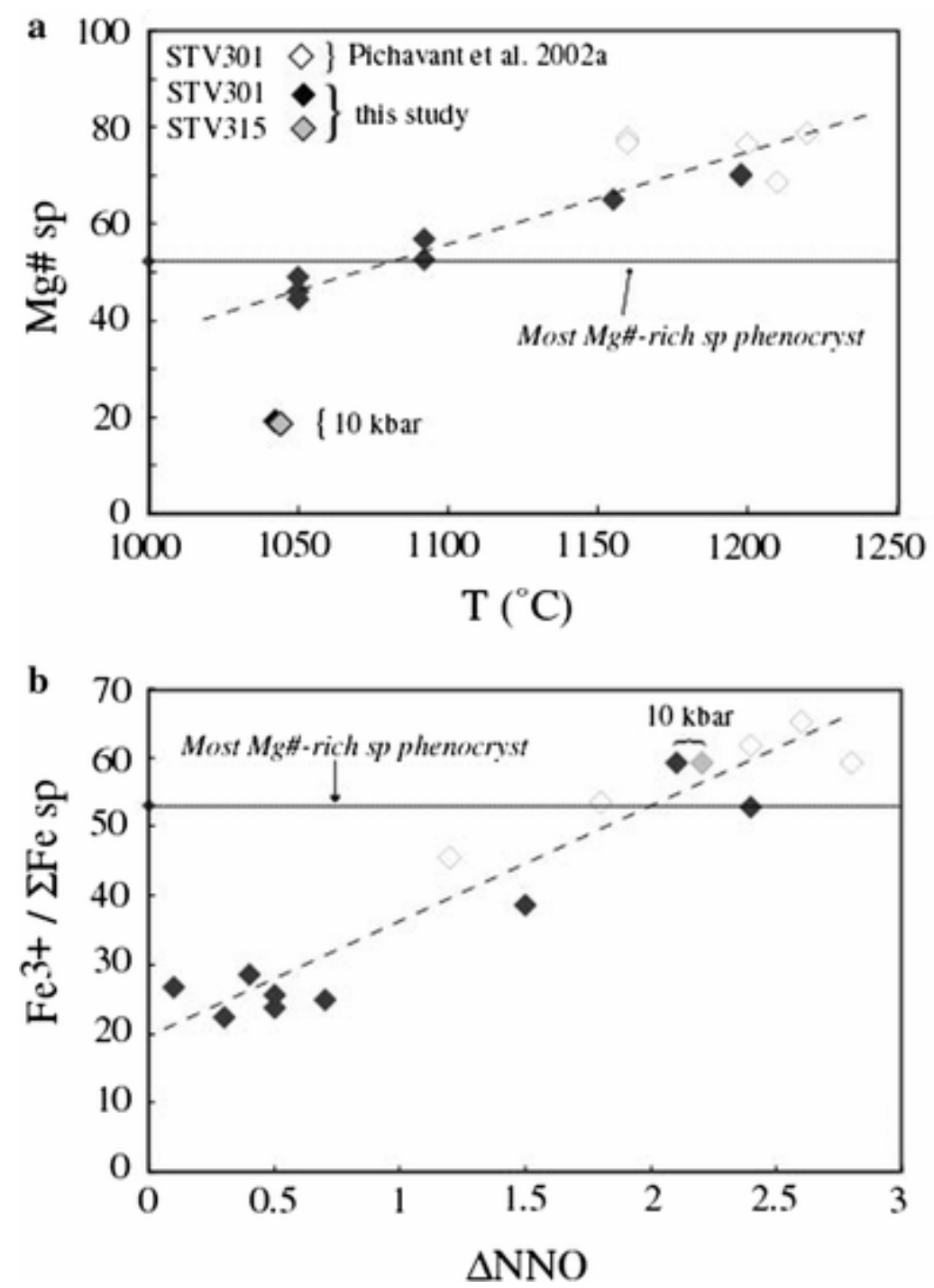

Fig. 13 Compositions of experimental spinels. (a) $\mathrm{Mg} \#$ vs. temperature; (b) $\mathrm{Fe}^{3+} / \Sigma$ Fe versus $\Delta \mathrm{NNO}$. $\mathrm{Cr}-\mathrm{Al}$ spinels and magnetite plotted with the same symbol. Data from this study (black and grey symbols) at $4 \mathrm{kbar}$ except otherwise stated (10 kbar), and from Pichavant et al. (2002a) at 10-15 kbar (open symbols). The horizontal lines drawn give the $\mathrm{Mg \#} \mathrm{(a)} \mathrm{and} \mathrm{the} \mathrm{Fe}^{3+} / \Sigma \mathrm{Fe}$ (b) of the most $\mathrm{Mg \# -rich} \mathrm{sp} \mathrm{of} \mathrm{the} \mathrm{Soufriere} \mathrm{suite,}$ respectively (see Fig. 12). Dashed lines are hand-drawn regressions of the experimental data points. In a, the two $10 \mathrm{kbar}$ magnetites have lower $\mathrm{Mg} \#$ than the regression line since they coexist with high amounts of Mg-rich hornblende (Table 3). Corrected spinel compositions plotted for experiments $<1,100^{\circ} \mathrm{C}$ (see text) 


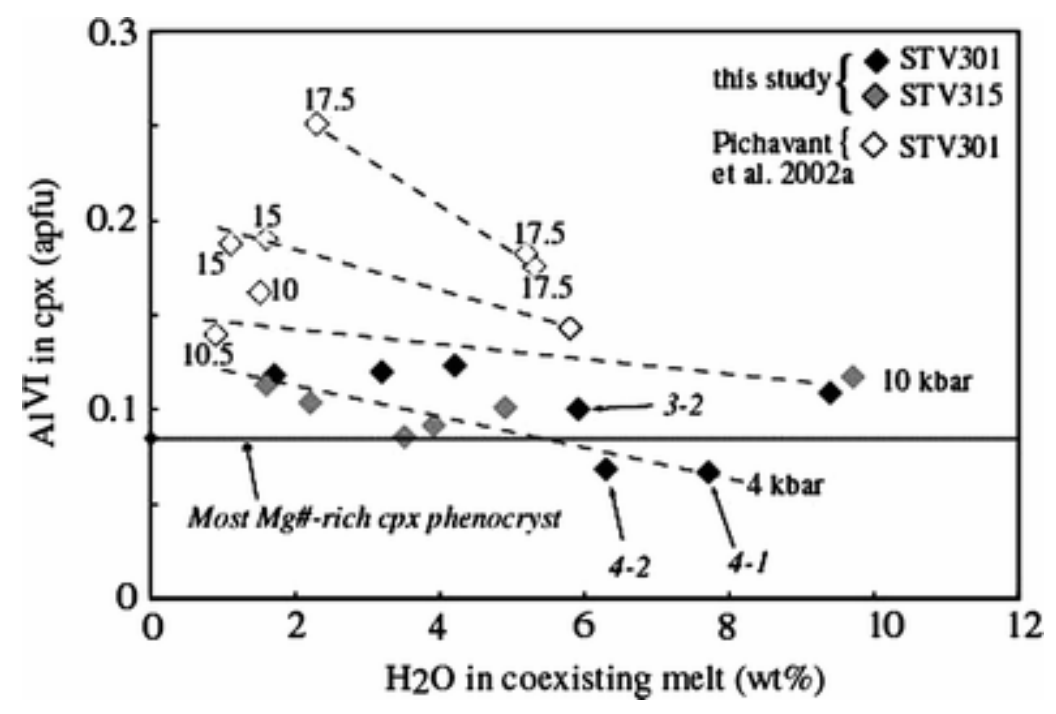

Fig. $14 \mathrm{Al}^{\mathrm{VI}}$ in experimental clinopyroxenes (atom per formula unit, apfu) plotted as a function of the $\mathrm{H}_{2} \mathrm{O}$ content of the coexisting melt (wt \%) for STV301 at different pressures and STV315 at $4 \mathrm{kbar}$. Experimental data at 4 and $10 \mathrm{kbar}$ (black and grey symbols) from this study; Experimental data at 10-17.5 kbar (open symbols) from Pichavant et al. (2002a) with data points labelled with pressure in kbar. The horizontal line drawn gives the $\mathrm{Al}^{\mathrm{VI}}$ of the most Mg\#-rich cpx of the Soufriere suite (see Fig. 11). Dashed lines are hand-drawn regressions of the experimental data points. 4-1, 4-2, 3-2 refer to experimental charges (Table 3) 
Tables

Table 1 Major element compositions

\begin{tabular}{|c|c|c|c|c|c|c|}
\hline \multirow{2}{*}{ Sample } & \multicolumn{2}{|l|}{ STV301 } & \multicolumn{2}{|l|}{ STV315 } & \multirow{2}{*}{ PAR1 } & \multirow{2}{*}{ PAR2 } \\
\hline & Whole-rock $^{\mathbf{a}}$ & Glass $^{\mathrm{b}}$ & Whole-rock $^{\mathbf{a}}$ & Glass ${ }^{\mathrm{c}}$ & & \\
\hline $\mathrm{SiO}_{2}(\mathrm{wt} \%)$ & 47.01 & $46.9(4)$ & 51.20 & $51.3(3)$ & 48.05 & 48.44 \\
\hline $\mathrm{TiO}_{2}$ & 1.07 & $1.08(3)$ & 0.82 & $0.77(8)$ & 1.17 & 1.15 \\
\hline $\mathrm{Al}_{2} \mathrm{O}_{3}$ & 15.28 & $15.3(2)$ & 16.88 & 16.9(1) & 16.51 & 17.01 \\
\hline $\mathrm{FeO}_{\mathrm{t}}$ & 8.79 & $8.96(17)^{\mathrm{d}}$ & 8.06 & $8.43(31)$ & 9.07 & 8.65 \\
\hline $\mathrm{MnO}$ & 0.16 & $0.17(3)$ & 0.16 & $0.16(9)$ & 0.16 & 0.13 \\
\hline $\mathrm{MgO}$ & 12.50 & $12.0(1)$ & 7.76 & $7.64(11)$ & 9.90 & 10.55 \\
\hline $\mathrm{CaO}$ & 10.96 & $11.0(1)$ & 10.55 & $10.6(2)$ & 11.88 & 10.99 \\
\hline $\mathrm{Na}_{2} \mathrm{O}$ & 2.23 & $2.27(7)$ & 2.33 & $2.59(12)$ & 2.45 & 2.33 \\
\hline $\mathrm{K}_{2} \mathrm{O}$ & 0.47 & $0.49(2)$ & 0.33 & $0.34(5)$ & 0.52 & 0.53 \\
\hline $\mathrm{H}_{2} \mathrm{O}$ & ND & $0.10^{\mathrm{e}}$ & ND & ND & 0 & 0 \\
\hline Total & 98.47 & 98.27 & 98.09 & 98.73 & 99.71 & 99.78 \\
\hline $\mathrm{Cr}(\mathrm{ppm})$ & 728 & 680 & 303 & 140 & & \\
\hline $\mathrm{Ni}$ & 250 & ND & 75 & ND & & \\
\hline \multicolumn{7}{|l|}{ CIPW norm } \\
\hline $\mathrm{q}$ & - & & 1.29 & & - & - \\
\hline or & 2.78 & & 1.95 & & 3.07 & 3.13 \\
\hline $\mathrm{ab}$ & 18.48 & & 15.54 & & 14.04 & 14.99 \\
\hline an & 29.64 & & 38.80 & & 37.59 & 39.11 \\
\hline ne & 0.56 & & - & & 0.88 & - \\
\hline di & 19.32 & & 14.37 & & 21.34 & 16.21 \\
\hline hy & - & & 22.77 & & - & 4.29 \\
\hline ol & 23.67 & & - & & 18.53 & 17.92 \\
\hline $\mathrm{mt}$ & 2.13 & & 1.94 & & 2.19 & 2.09 \\
\hline il & 2.03 & & 1.56 & & 2.22 & 2.18 \\
\hline \multicolumn{7}{|c|}{ Vol\% phenocrysts } \\
\hline Olivine & 22.0 & & 11.2 & & & \\
\hline Spinel & 4.3 & & 3.0 & & & \\
\hline Clinopyroxene & 6.2 & & 5.1 & & & \\
\hline Plagioclase & - & & 45.9 & & & \\
\hline Orthopyroxene & - & & Trace & & & \\
\hline
\end{tabular}

${ }^{a}$ XRF spectrometry (Heath et al. 1998)

${ }^{\mathrm{b}}$ Average of 41 electron microprobe analyses (Pichavant et al. 2002a); numbers in brackets are standard deviations in terms of least unit cited

${ }^{\mathrm{c}}$ Average of 10 electron microprobe analyses

${ }^{\mathrm{d}} \mathrm{FeO}=1.52 \mathrm{wt} \%$ and $\mathrm{Fe}_{2} \mathrm{O}_{3}=8.26 \mathrm{wt} \% ; \mathrm{Fe}^{3+} / \mathrm{Fe}^{2+}$ (at.) determined by Mössbauer spectroscopy (Pichavant et al. 2002a)

${ }^{\mathrm{e}} \mathrm{H}_{2} \mathrm{O}$ by Karl-Fischer titration

For all CIPW calculations, at. $\mathrm{Fe}^{3+} /$ total $\mathrm{Fe}=0.15$. PAR1 and PAR2 are calculated compositions of liquids parental to the Soufriere suite (see text) 
Table 2 Representative electron microprobe analyses of phenocrysts

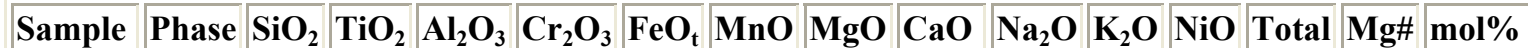

\begin{tabular}{|c|c|c|c|c|c|c|c|c|c|c|c|c|c|c|c|}
\hline \multirow{4}{*}{ TV3 } & & 40.8 & 0.02 & 0.03 & 0.03 & 11.4 & 0.19 & 48.5 & 0.17 & 0.01 & NA & 0.22 & 101.4 & 88.3 & $\mathrm{Fo}_{88.3}$ \\
\hline & $\mathrm{O}$ & 8.9 & 02 & 0.01 & 0.01 & 0.9 & 0.48 & .2 & 25 & 0 & A & 09 & 100.9 & 77.4 & $\mathrm{Fo}_{777}$ \\
\hline & $\mathrm{Cpx}$ & 48.6 & 0.91 & 6.42 & .69 & 5.43 & 0.09 & 14.2 & 22.2 & 0.23 & $\mathrm{NA}$ & 0.02 & 98.9 & 85.0 & $\mathrm{E}$ \\
\hline & $\mathrm{Sp}$ & 0.09 & 0.49 & 17.6 & 43.0 & 29.6 & 0.45 & 8.97 & 0.10 & NA & A & 0.08 & 100.5 & 42.8 & C \\
\hline \multirow{6}{*}{ STV315 } & 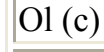 & 40.8 & 0.03 & 0.02 & 0.04 & 11.3 & 0.22 & 48.7 & 0.18 & 0.01 & A & 0.17 & 101.5 & 88.4 & Fo \\
\hline & $\mathrm{Ol}(\mathrm{r})$ & 39.3 & 0.04 & 0.02 & 0.04 & 20.1 & 0.36 & 40.7 & 0.19 & 0.01 & NA & 0.09 & 100.9 & 78.3 & Fo \\
\hline & Cpx & 51.8 & 0.44 & 2.19 & 0.03 & 9.97 & 0.41 & 15.29 & 19.32 & 0.27 & NA & 0.04 & 99.7 & 75.0 & $\mathrm{En}_{4}$ \\
\hline & Plag & 44.9 & NA & 35.9 & IA & 0.45 & na & 0.05 & 18.61 & 0.73 & 0.00 & NA & 100.6 & 19.0 & A \\
\hline & Opx & 53.6 & 0.23 & 0.96 & 0.0 & 19.4 & 0.7 & 24.5 & 1.63 & 0.04 & NA & 0.02 & 101.2 & 70.4 & $\operatorname{En}_{68} \mathrm{~W}$ \\
\hline & $\mathrm{Sp}$ & 0.03 & 4.27 & 6.77 & 20.5 & 59.2 & 0.42 & 4.41 & 0.00 & NA & NA & 0.10 & 95.7 & 21.3 & $\mathrm{Cr}_{67}$ \\
\hline
\end{tabular}

Ol olivine, Plag plagioclase, Opx orthopyroxene, Cpx clinopyroxene, $\mathrm{Sp}, \mathrm{Cr}-\mathrm{Al}$ spinel; $c$ core, $r$ rim, NA not analyzed $\mathrm{Mg} \#=100 *$ at. $\mathrm{Mg} /\left(\mathrm{Mg}+\mathrm{Fe}^{2+}\right), \mathrm{Fo}=100 *$ at. $\mathrm{Mg} /(\mathrm{Mg}+\mathrm{Fe})$ in olivine, $\mathrm{Cr} \#=100 * \mathrm{at} ; \mathrm{Cr} /(\mathrm{Cr}+\mathrm{Al})$ in spinel, $\mathrm{En}=100 *$ at. $\mathrm{Mg} /\left(\mathrm{Mg}+\mathrm{Fe}^{2+}+\mathrm{Ca}\right), \mathrm{Wo}=100 *$ at. $\mathrm{Ca} /\left(\mathrm{Mg}+\mathrm{Fe}^{2+}+\mathrm{Ca}\right)$ in pyroxene, $\mathrm{An}=100 *$ at.

$\mathrm{Ca} /(\mathrm{Ca}+\mathrm{Na}+\mathrm{K}), \mathrm{Or}=100 *$ at. $\mathrm{K} /(\mathrm{Ca}+\mathrm{Na}+\mathrm{K})$ in plagioclase 

Table 3 Experimental conditions and results

\begin{tabular}{|c|c|c|c|c|c|c|c|c|c|c|c|}
\hline Charge & $\begin{array}{l}\mathrm{H}_{2} \mathrm{O} \text { melt } \\
\text { wt\% }\end{array}$ & $\mathbf{a H}_{2} \mathbf{O}$ & $\begin{array}{l}\operatorname{logfO}_{2} \\
\text { bar }\end{array}$ & $\begin{array}{l}\Delta \mathrm{NNO} \\
\text { bar }\end{array}$ & Phase assemblage $^{\mathrm{a}}$ & $\sum_{2} R$ & $\begin{array}{l}\mathrm{Fe} \\
\operatorname{loss}^{\mathrm{b}} \%\end{array}$ & \begin{tabular}{|l}
$\mathrm{Kd}^{\mathrm{Fe}-}$ \\
$\mathrm{Mg}_{\mathrm{O}} \mathrm{Ol}-\mathrm{I}$
\end{tabular} & $\begin{array}{l}K_{d}^{\mathrm{Fe}-} \\
{ }^{\mathrm{Mg}_{\mathrm{g}}} \mathrm{Cpx}-1\end{array}$ & $\begin{array}{l}\mathbf{K d}^{\mathrm{Fe}-} \\
{ }_{\mathrm{Mg}} \mathbf{O p x}-\mathbf{I}\end{array}$ & $\begin{array}{l}\text { Kd }^{\text {Na-Ca }} \\
\text { Plag-l }\end{array}$ \\
\hline \multicolumn{12}{|c|}{ Run $4,4,002$ bars, $1,050^{\circ} \mathrm{C}, \mathrm{fH}_{2}=12.6$ bars, $23 \mathrm{~h}, \mathrm{XNi}=0.46, \mathrm{Au}$ capsules } \\
\hline \multicolumn{12}{|l|}{ STV301 } \\
\hline $4-1$ & $7.7^{\mathrm{e}}$ & 0.91 & -8.8 & +0.7 & $\begin{array}{l}\mathrm{Gl}(81), \mathrm{Ol}(12), \mathrm{Cpx}(6), \mathrm{Sp}(1), \\
\mathrm{qu}\end{array}$ & 0.07 & -1 & 0.28 & 0.21 & & \\
\hline $4-2$ & $6.3^{\mathrm{e}}$ & 0.66 & -9.1 & +0.5 & $\begin{array}{l}\mathrm{Gl}(69), \mathrm{Ol}(12), \mathrm{Cpx}(18), \\
\mathrm{Sp}(1), \mathrm{qu}\end{array}$ & 0.07 & +1 & 0.29 & 0.17 & & \\
\hline \multirow[t]{2}{*}{$4-3$} & $5.9^{\mathrm{e}}$ & 0.60 & -9.2 & +0.4 & $\begin{array}{l}\text { Gl(51), Ol(15), Cpx,(23) } \\
\text { Plag(10) }\end{array}$ & 0.05 & 0 & 0.28 & 0.22 & & 4.49 \\
\hline & & & & & $\operatorname{Sp}(1), q u$ & & & & & & \\
\hline \multicolumn{12}{|l|}{ STV315 } \\
\hline $4-4$ & $4.9^{\mathrm{e}}$ & 0.57 & -9.2 & +0.3 & $\mathrm{Gl}(92), \mathrm{Ol}(4), \mathrm{Cpx}(4), \mathrm{qu}$ & 0.40 & -6 & 0.30 & 0.35 & & \\
\hline $4-5$ & $3.9^{\mathrm{e}}$ & 0.40 & -9.5 & +0.0 & $\begin{array}{l}\text { Gl(78), Ol(5), Cpx(13), } \\
\text { Plag(4), qu }\end{array}$ & 0.11 & -3 & 0.34 & 0.25 & & 3.19 \\
\hline \multirow[t]{2}{*}{$4-6$} & $2.2^{\mathrm{e}}$ & 0.18 & -10.2 & -0.7 & $\begin{array}{l}\mathrm{Gl}(64), \mathrm{Ol}(12), \mathrm{Cpx}(22), \\
\mathrm{Opx}(-10)\end{array}$ & 0.11 & +1 & 0.28 & 0.25 & 0.26 & 3.14 \\
\hline & & & & & Plag(12), qu & & & & & & \\
\hline \multicolumn{12}{|c|}{ Run $3,4,015$ bars, $1,092^{\circ} \mathrm{C}, \mathrm{fH}_{2}=13.2$ bars, $22.5 \mathrm{~h}, \mathrm{XNi}=0.45, \mathrm{AgPd}$ capsules } \\
\hline \multicolumn{12}{|l|}{ STV301 } \\
\hline $3-1$ & $5.1^{\mathrm{e}}$ & 0.63 & -8.5 & +0.5 & $\mathrm{Gl}(88), \mathrm{Ol}(11), \mathrm{Sp}(1), \mathrm{qu}$ & 0.07 & +1 & 0.33 & & & \\
\hline $3-2$ & $4.2^{\mathrm{e}}$ & 0.44 & -8.8 & +0.1 & $\begin{array}{l}\mathrm{Gl}(73), \mathrm{Ol}(12), \mathrm{Cpx}(14) \\
\mathrm{Sp}(1), \mathrm{qu}\end{array}$ & 0.06 & +1 & 0.31 & 0.29 & & \\
\hline \multirow[t]{2}{*}{$3-3$} & $3.2^{\mathrm{e}}$ & 0.30 & -9.2 & -0.2 & $\begin{array}{l}\text { Gl(39), Ol(18), Cpx(21), } \\
\text { Plag(22) }\end{array}$ & 1.02 & -10 & ND & ND & & ND \\
\hline & & & & & qu & & & & & & \\
\hline
\end{tabular}




\begin{tabular}{|c|c|c|c|c|c|c|c|c|c|c|c|}
\hline Charge & $\begin{array}{l}\mathrm{H}_{2} \mathrm{O} \text { melt } \\
\mathrm{wt} \%\end{array}$ & $\mathbf{a H}_{2} \mathbf{O}$ & $\begin{array}{l}\operatorname{logfO} O_{2} \\
\text { bar }\end{array}$ & $\begin{array}{l}\Delta \text { NNO } \\
\text { bar }\end{array}$ & Phase assemblage $^{a}$ & $\sum_{2} \boldsymbol{R} R$ & $\begin{array}{l}\text { Fe } \\
\operatorname{loss}^{b_{0}} \%\end{array}$ & $\begin{array}{l}\mathrm{Kd}^{\mathrm{Fe}-} \\
\mathrm{Mg}^{\mathrm{O}} \mathrm{Ol}-\mathrm{l}\end{array}$ & $\begin{array}{l}\mathrm{Kd}^{\mathrm{Fe}-} \\
{ }^{\mathrm{Mg}} \mathrm{Cpx}-\mathrm{I}\end{array}$ & $\begin{array}{l}\mathrm{Kd}^{\mathrm{Fe}-} \\
{ }_{\mathrm{Mg}} \mathrm{Opx}-\mathrm{I}\end{array}$ & $\begin{array}{l}\text { Kd }^{\mathrm{Na}-\mathrm{Ca}} \\
\text { Plag-I }\end{array}$ \\
\hline \multicolumn{12}{|l|}{ STV315 } \\
\hline $3-5$ & $4.9^{\mathrm{e}}$ & 0.59 & -8.6 & +0.4 & $\mathrm{Gl}(97), \mathrm{Ol}(3)$ & 0.44 & -7 & & 0.36 & & \\
\hline \multirow[t]{2}{*}{$3-6$} & $3.5^{\mathrm{e}}$ & 0.39 & -8.9 & +0.0 & $\begin{array}{l}\mathrm{Gl}(62), \mathrm{Ol}(7), \mathrm{Cpx}(13) \\
\mathrm{Plag}(18)\end{array}$ & 0.08 & 0 & 0.35 & 0.30 & 0.29 & 1.62 \\
\hline & & & & & Opx(tr), qu & & & & & & \\
\hline \multicolumn{12}{|c|}{ Run $6,4,147$ bars, $1155^{\circ} \mathrm{C}, \mathrm{fH}_{2}=14.0$ bars, $13 \mathrm{~h}, \mathrm{XNi}=0.43$, AgPd capsules } \\
\hline \multicolumn{12}{|l|}{ STV301 } \\
\hline $6-1$ & $4.2^{\mathrm{d}}$ & 0.49 & -7.9 & +0.3 & $\mathrm{Gl}(88), \mathrm{Ol}(11), \mathrm{Sp}(1), \mathrm{qu}$ & 0.08 & -3 & & 0.35 & & \\
\hline $6-2$ & $1.7^{\mathrm{e}}$ & 0.14 & -9.0 & -0.8 & $\begin{array}{l}\mathrm{Gl}(54), \mathrm{Ol}(16), \mathrm{Cpx}(12), \\
\mathrm{Plag}(18)\end{array}$ & 0.05 & -2 & 0.29 & 0.27 & & 1.28 \\
\hline \multicolumn{12}{|l|}{ STV315 } \\
\hline $6-4$ & $3.2^{\mathrm{e}}$ & 0.36 & -8.1 & +0.0 & Gl(100) & 0.27 & -4 & & & & \\
\hline $6-5$ & $1.6^{\mathrm{e}}$ & 0.14 & -9.0 & -0.8 & $\begin{array}{l}\mathrm{Gl}(73), \operatorname{Opx}(5), \mathrm{Cpx}(8), \\
\operatorname{Plag}(14)\end{array}$ & 0.20 & -3 & & 0.36 & 0.31 & 1.36 \\
\hline \multicolumn{12}{|c|}{ Run $7,4,204$ bars, $1,198^{\circ} \mathrm{C}, \mathrm{fH}_{2}=1.7$ bars, $25 \mathrm{~h}, \mathrm{XNi}=0.12, \mathrm{AgPd}$ capsules } \\
\hline \multicolumn{12}{|l|}{ STV301 } \\
\hline $7-2$ & $4.7^{\mathrm{d}}$ & 0.63 & -5.3 & +2.4 & $\mathrm{Gl}(96), \mathrm{Ol}(3), \mathrm{Sp}(1), \mathrm{qu}$ & 0.02 & +1 & & 0.37 & & \\
\hline $7-3$ & $2.3^{\mathrm{d}}$ & 0.23 & -6.1 & +1.5 & $\mathrm{Gl}(91), \mathrm{Ol}(8), \mathrm{Sp}(1), \mathrm{qu}$ & 0.05 & -2 & & 0.37 & & \\
\hline \multicolumn{12}{|l|}{ STV315 } \\
\hline $7-4$ & $5.1^{\mathrm{f}}$ & 0.65 & -5.2 & +2.4 & $\mathrm{Gl}(100), \mathrm{qu}$ & 0.80 & -4 & & & & \\
\hline $7-5$ & $3.3^{\mathrm{e}}$ & 0.37 & -5.7 & +2.0 & Gl(100) & 0.43 & -4 & & & & \\
\hline $7-6$ & $2.0^{\mathrm{e}}$ & 0.18 & -6.4 & +1.3 & Gl(100) & 1.04 & -7 & & & & \\
\hline \multicolumn{12}{|c|}{ Run $1,9,577$ bars, $1,044^{\circ} \mathrm{C}, \mathrm{fH}_{2}=6.0$ bars, $17 \mathrm{~h}, \mathrm{XNi}=0.15$} \\
\hline \multicolumn{12}{|l|}{ STV301 } \\
\hline $1-9(\mathrm{Pt})$ & $9.4^{\mathrm{e}}$ & 0.59 & -7.4 & +2.1 & $\mathrm{Gl}(29), \operatorname{Amph}(64), \mathrm{Cpx}(2)$ & 0.28 & $0^{\mathrm{b}}$ & & & & 0.35 \\
\hline
\end{tabular}




\begin{tabular}{|c|c|c|c|c|c|c|c|c|c|c|c|}
\hline Charge & $\begin{array}{l}\mathrm{H}_{2} \mathrm{O} \text { melt } \\
\mathrm{wt} \%\end{array}$ & $\mathbf{a} \mathbf{H}_{2} \mathbf{O}$ & $\begin{array}{l}\operatorname{logfO} O_{2} \\
\text { bar }\end{array}$ & $\begin{array}{l}\Delta \mathrm{NNO} \\
\text { bar }\end{array}$ & Phase assemblage $^{a}$ & $\sum_{2} R$ & $\begin{array}{l}\text { Fe } \\
\operatorname{loss}^{b_{0}} \%\end{array}$ & $\begin{array}{l}\mathrm{Kd}^{\mathrm{Fe}-} \\
{ }_{\mathrm{Mg}} \mathrm{Ol}-\mathrm{I}\end{array}$ & $\begin{array}{l}\mathrm{Kd}^{\mathrm{Fe}-} \\
{ }^{\mathrm{Mg}_{\mathrm{C}} \mathrm{Cl}}-\mathrm{l}\end{array}$ & $\begin{array}{l}\mathrm{Kd}^{\mathrm{Fe}-} \\
{ }^{\mathrm{Gg}} \mathrm{Opx}-\mathbf{l}\end{array}$ & $\begin{array}{l}\text { Kd } \\
\text { Plag-Ca }\end{array}$ \\
\hline & & & & & $\operatorname{Mt}(5)$ & & & & & & \\
\hline \multicolumn{12}{|l|}{ STV315 } \\
\hline $\begin{array}{l}1- \\
5(\mathrm{AgPd})\end{array}$ & $9.7^{\mathrm{e}}$ & 0.62 & -7.4 & +2.2 & $\begin{array}{l}\text { Gl(52), Amph(33), Cpx(8), } \\
\operatorname{Mt}(7)\end{array}$ & 0.68 & $0^{\mathrm{b}}$ & & & & 0.44 \\
\hline
\end{tabular}

$\mathrm{H}_{2} \mathrm{O}$ calculated from $\mathrm{H}_{2} \mathrm{O}$ melt using the model of Burnham (1979); $\mathrm{XNi}=$ mole fraction of $\mathrm{Ni}$ in the alloy phase of the sensor; log fO $\mathrm{O}_{2}$ calculated from experimental $\mathrm{fH}_{2}$ and $\mathrm{fH}_{2} \mathrm{O}$ (determined from $\mathrm{aH}_{2} \mathrm{O}$ ); $\Delta \mathrm{NNO}=\log \mathrm{fO}_{2}-\log \mathrm{fO}_{2}$ of the $\mathrm{NNO}$ buffer calculated at $P$ and $T$ (Pownceby and O'Neill, 1994); $N D$ not determined, tr: a trace of (phase proportion $<1 \%$ by weight)

${ }^{a}$ Phase proportions calculated by mass balance; Gl glass, Ol olivine, Plag plagioclase, Opx orthopyroxene, Cpx clinopyroxene, Sp spinel, Mt magnetite, Amph amphibole, qu quench crystals (detected by SEM)

${ }^{\mathrm{b}} \mathrm{Fe}$ loss probably underestimated (see text)

${ }^{\mathrm{c}}$ Apparent loss or gain of $\mathrm{FeO}$ (total $\mathrm{Fe}$ as $\mathrm{FeO}$ ) calculated as $100 *\left(\mathrm{FeOcalc}-\mathrm{FeO}\right.$ starting sample)/FeOstarting sample. FeOcalc and $\Sigma R^{2}$ are obtained from the mass-balance calculations.

${ }^{\mathrm{d}}$ Analyzed by SIMS

${ }^{\mathrm{e}}$ Estimated using the by difference method

${ }^{\mathrm{f}}$ Analyzed by Karl-Fischer titration 

Table 4 Experimental compositions

\begin{tabular}{|c|c|c|c|c|c|c|c|c|c|c|c|c|c|}
\hline Charge & Phase & $\mathrm{SiO}_{2}$ & $\mathrm{TiO}_{2}$ & $\mathrm{Al}_{2} \mathrm{O}_{3}$ & $\mathrm{Cr}_{2} \mathrm{O}_{3}$ & $\mathrm{FeO}_{\mathrm{t}}$ & MnO & MgO & $\mathrm{CaO}$ & $\mathrm{Na}_{2} \mathrm{O}$ & $\mathbf{K}_{2} \mathbf{O}$ & & \\
\hline \multicolumn{14}{|c|}{ Run 0,1 bar, $1,400^{\circ} \mathrm{C}$, Air, $2 \times 3 \mathrm{~h}$, Pt capsules } \\
\hline STV301 & $\operatorname{Gl}\left(41^{b}\right)$ & $47.8\left(4^{c}\right)$ & $1.10(3)$ & $15.6(2)$ & 1) & 7) & ) & 1 & 1) & 7) & ) & 8.3 & 39.0 \\
\hline STV315 & $\mathrm{Gl}($ & $52.0(3)$ & $0.78(8)$ & $17.1(1)$ & $0.02(4)$ & $8.54(31)$ & $0.16(9)$ & 1) & 7(2) & $2(12)$ & $0.34(5)$ & 98.7 & 4.4 \\
\hline \multicolumn{14}{|c|}{ Run $4,4,002$ bars, $1,050^{\circ} \mathrm{C}, \mathrm{fH}_{2}=12.6$ bars, $23 \mathrm{~h}, \mathrm{XNi}=0.46$, Au capsules } \\
\hline \multicolumn{14}{|l|}{ STV301 } \\
\hline \multirow{4}{*}{ 4-1 } & $\mathrm{Gl}(5)$ & $49.4(2)$ & $1.29(8)$ & $18.9(1)$ & $0.01(1)$ & $8.31(25)$ & $0.16(5)$ & $6.40(16)$ & $3(2)$ & (13) & $0.59(3)$ & 90.1 & 64.6 \\
\hline & $\mathrm{O} 1(10)$ & $39.5(2)$ & $0.05(5)$ & $0.04(2)$ & $0.03(3)$ & $12.8(11)$ & $0.29(8)$ & $46.3(8)$ & $0.20(4)$ & $0.01(2)$ & $0.00(1)$ & 99.2 & Fo86.6 \\
\hline & $\operatorname{Cpx}(6$ & $48.1(8)$ & $0.85(9)$ & $5.94(83)$ & $0.20(13)$ & $6.15(58)$ & $0.12(11)$ & $15.0(6)$ & $22.0(4)$ & $0.30(12)$ & $0.03(3)$ & 98.7 & En46Wo49 \\
\hline & $\operatorname{Sp}(3)$ & $0.31(28)$ & $2.62(46)$ & $23.6(5)$ & $17.3(3)$ & $40.4(12)$ & $0.16(3)$ & $10.9(3)$ & $0.16(9)$ & $0.04(5)$ & $0.01(1)$ & 95.5 & Cr\#32.9 \\
\hline \multirow{4}{*}{$4-2$} & $\mathrm{Gl}(5)$ & $50.2(3)$ & $1.41(9)$ & $20.7(4)$ & $0.03(6)$ & $8.14(22)$ & $0.15(4)$ & $5.19(39)$ & $10.5(4)$ & $3.00(14)$ & $0.67(8)$ & 91.7 & $\mathrm{Mg} \# 59.1$ \\
\hline & $\mathrm{Ol}(6)$ & $39.1(2)$ & $0.01(2)$ & $0.07(9)$ & $0.00(0)$ & $15.5(12)$ & $0.27(2)$ & $43.7(10)$ & $0.23(6)$ & $0.01(2)$ & $0.02(2)$ & 98.9 & Fo83.4 \\
\hline & Cpx(4) & $47.5(7)$ & $0.84(16)$ & $6.47(45)$ & $0.12(6)$ & $7.07(25)$ & $0.14(8)$ & $15.2(7)$ & $21.2(6)$ & $0.34(9)$ & $0.01(3)$ & 98.9 & En47Wo47 \\
\hline & $\mathrm{Sp}(2)$ & $0.20(11)$ & $2.27(6)$ & $25.4(1)$ & $15.4(1)$ & $42.0(3)$ & $0.12(5)$ & $9.70(25)$ & $0.19(5)$ & $0.07(1)$ & $0.02(3)$ & 95.3 & $\mathrm{Cr} \# 28.9$ \\
\hline \multirow{5}{*}{$4-3$} & $\mathrm{Gl}(8)$ & $51.9(6)$ & $1.51(9)$ & $21.0(4)$ & $0.03(5)$ & $7.85(46)$ & $0.16(12)$ & $3.86(52)$ & $9.11(50)$ & $3.76(16)$ & $0.85(16)$ & 92.1 & $\mathrm{Mg} \# 52.2$ \\
\hline & $\mathrm{Ol}(7)$ & $38.8(3)$ & $0.07(4)$ & $0.06(8)$ & $0.05(8)$ & $18.4(5)$ & $0.30(14)$ & $41.5(2)$ & $0.20(4)$ & $0.03(4)$ & $0.02(2)$ & 99.4 & Fo80.0 \\
\hline & Cpx(9) & 48 & $0.88(12)$ & $6.55(31)$ & $0.12(6)$ & $7.19(40)$ & $0.17(3)$ & $\mid 14.9(3)$ & $20.4(3)$ & $0.38(4)$ & $0.02(3)$ & 99.3 & En46Wo45 \\
\hline & Plag(3) & $45.7(1)$ & $0.06(7)$ & $33.1(2)$ & $0.00(0)$ & $0.68(11)$ & $0.03(5)$ & $0.14(3)$ & $17.4(2)$ & $1.60(10)$ & $0.07(3)$ & 98.8 & An85Or0 \\
\hline & $\mathrm{Sp}(3)$ & $0.22(12)$ & $1.66(27)$ & $24.1(61)$ & $17.6(25)$ & $41.2(52)$ & $8(6)$ & $9.93(12)$ & $0.19(3)$ & $0.03(2)$ & $0.02(1)$ & 95.0 & $\mathrm{Cr} \# 32.8$ \\
\hline \multicolumn{14}{|l|}{ STV315 } \\
\hline \multirow{3}{*}{$4-4$} & $\mathrm{Gl}(8)$ & $53.3(5)$ & $0.90(4)$ & $18.3(1)$ & $0.03(4)$ & $7.84(24)$ & $0.20(10)$ & $5.82(14)$ & $10.6(3)$ & $2.60(10)$ & $0.36(5)$ & 91.4 & $\mathrm{Mg} \# 62.6$ \\
\hline & $\mathrm{Ol}(3)$ & $40.5(1)$ & $0.03(3)$ & $0.03(3)$ & $0.03(5)$ & $14.3(10)$ & $0.32(5)$ & $44.2(6)$ & $0.17(10)$ & $0.01(1)$ & $0.02(1)$ & 99.7 & Fo84.6 \\
\hline & Cpx(5) & $48.8(9)$ & $0.69(15)$ & $6.3(12)$ & $0.50(17)$ & $6.77(9)$ & $0.13(8)$ & 14.1(8) & $21.4(11)$ & $0.36(8)$ & $0.02(2)$ & 99.1 & En44Wo47 \\
\hline $4-5$ & $\mathrm{Gl}(6)$ & $53.9(2)$ & $1.00(5)$ & 19.1(2) & $0.02(5)$ & $8.17(31)$ & $0.16(12)$ & $4.96(16)$ & $9.32(14)$ & $2.96(17)$ & $0.46(5)$ & 93.2 & $\mathrm{Mg} \# 56.9$ \\
\hline
\end{tabular}




\begin{tabular}{|c|c|c|c|c|c|c|c|c|c|c|c|c|c|}
\hline \multirow[t]{4}{*}{ Charge } & Phase & $\mathrm{SiO}_{2}$ & $\mathrm{TiO}_{2}$ & $\mathrm{Al}_{2} \mathrm{O}_{3}$ & $\mathrm{Cr}_{2} \mathrm{O}_{3}$ & $\mathrm{FeO}_{\mathrm{t}}$ & MnO & MgO & $\mathrm{CaO}$ & $\mathrm{Na}_{2} \mathrm{O}$ & $\mathrm{K}_{2} \mathrm{O}$ & Total $^{\mathrm{a}}$ & mol\% \\
\hline & $\mathrm{Ol}(2)$ & $39.4(2)$ & $0.05(7)$ & $0.06(2)$ & $0.07(2)$ & $18.6(2)$ & $0.29(4)$ & $40.4(4)$ & $0.26(3)$ & $0.00(0)$ & $0.00(0)$ & 99.2 & Fo79.5 \\
\hline & Сpx(6) & $48.2(10)$ & $0.63(4)$ & $6.50(34)$ & $0.30(21)$ & $7.84(64)$ & $0.23(9)$ & $15.0(2)$ & $20.0(4)$ & $0.37(5)$ & $0.03(3)$ & 99.1 & En46Wo45 \\
\hline & Plag(1) & 47.8 & 0.01 & 31.8 & 0.05 & 1.15 & 0.00 & 0.45 & 16.8 & 1.68 & 0.09 & 99.9 & An840r0 \\
\hline \multirow{5}{*}{$4-6$} & $\mathrm{Gl}(2)$ & $56.5(5)$ & $1.19(2)$ & 19.2(2) & $0.00(0)$ & $8.43(2)$ & $0.15(4)$ & $3.61(4)$ & $7.36(42)$ & $3.06(0)$ & $0.53(1)$ & 95.8 & $\mathrm{Mg \# 46.7}$ \\
\hline & $\mathrm{Ol}(5)$ & $37.7(4)$ & $0.02(2)$ & $0.05(6)$ & $0.00(0)$ & $21.7(4)$ & $0.37(9)$ & $38.9(2)$ & $0.26(6)$ & $0.03(2)$ & $0.00(0)$ & 99.1 & Fo76.1 \\
\hline & Сpx(4) & $49.0(2)$ & $0.81(21)$ & $6.11(115)$ & $0.23(6)$ & $8.58(55)$ & $0.14(11)$ & $14.4(10)$ & 19.2(8) & $0.47(8)$ & $0.06(5)$ & 98.9 & En45Wo43 \\
\hline & Opx (6) & $51.8(5)$ & $0.32(14)$ & $4.66(89)$ & $0.29(8)$ & $13.9(4)$ & $0.38(9)$ & $25.6(132)$ & $2.22(43)$ & $0.07(8)$ & $0.03(4)$ & 99.3 & En74Wo5 \\
\hline & $\operatorname{Plag}(1)$ & 48.1 & 0.00 & 32.6 & 0.00 & 0.79 & 0.05 & 0.11 & 16.5 & 2.18 & 0.06 & 100.3 & An80Or0 \\
\hline \multicolumn{14}{|c|}{ Run $3,4,015$ bars, $1,092^{\circ} \mathrm{C}, \mathrm{fH}_{2}=13.2$ bars, $22,5 \mathrm{~h}, \mathrm{XNi}=0.45, \mathrm{AgPd}$ capsules } \\
\hline \multicolumn{14}{|l|}{ STV301 } \\
\hline \multirow{3}{*}{$3-1$} & $\mathrm{Gl}(7)$ & $49.6(3)$ & $1.19(7)$ & $17.5(2)$ & $0.05(5)$ & $8.26(17)$ & $0.22(8)$ & $7.49(18)$ & $12.8(2)$ & $2.38(11)$ & $0.57(2)$ & 92.2 & Mg\#67.6 \\
\hline & $\mathrm{Ol}(14)$ & $39.8(5)$ & $0.03(4)$ & $0.12(13)$ & $0.10(11)$ & $12.8(3)$ & $0.17(8)$ & $46.0(5)$ & $0.30(4)$ & $0.02(2)$ & $0.01(1)$ & 99.3 & Fo86.5 \\
\hline & $\mathrm{Sp}(2)$ & $0.19(3)$ & $1.59(8)$ & $23.1(1)$ & $16.7(6)$ & $41.3(6)$ & $0.00(0)$ & $11.40(4)$ & $0.29(1)$ & $0.00(0)$ & $0.02(3)$ & 94.6 & $\mathrm{Cr} \# 32.6$ \\
\hline \multirow{4}{*}{$3-2$} & $\mathrm{Gl}(7)$ & $50.0(4)$ & $1.38(5)$ & 19.4(1) & $0.02(3)$ & $8.27(23)$ & $0.17(12)$ & $6.10(12)$ & 11.1(2) & $2.87(6)$ & $0.67(6)$ & 93.4 & $\mathrm{Mg} \# 62.0$ \\
\hline & $\mathrm{Ol}(2)$ & $40.0(1)$ & $0.00(0)$ & $0.09(1)$ & $0.00(0)$ & $14.5(9)$ & $0.24(9)$ & $43.4(3)$ & $0.29(2)$ & $0.00(0)$ & $0.02(2)$ & 98.5 & Fo84.2 \\
\hline & Сpx(7) & 47.1(10) & $1.20(33)$ & $8.32(113)$ & $0.26(16)$ & $6.59(48)$ & $0.13(13)$ & 14.1(9) & 21.2(4) & $0.34(3)$ & $0.02(2)$ & 99.2 & En44Wo48 \\
\hline & $\operatorname{Sp}(2)$ & $0.25(1)$ & $2.43(13)$ & $25.8(3)$ & $18.5(1)$ & $36.2(16)$ & $0.21(2)$ & $13.0(3)$ & $0.22(4)$ & $0.01(1)$ & $0(0)$ & 96.6 & $\mathrm{Cr} \# 32.4$ \\
\hline \multirow{4}{*}{$3-3$} & $\mathrm{Gl}^{\mathrm{d}}$ & 53.5 & 2.00 & 18.3 & 0.00 & 8.62 & 0.00 & 4.54 & 7.73 & 4.00 & 1.27 & 94.9 & Mg\#52.9 \\
\hline & $\mathrm{Ol}(5)$ & $38.8(5)$ & $0.08(7)$ & $0.17(18)$ & $0.02(3)$ & 18.2(3) & $0.26(8)$ & $41.4(3)$ & $0.38(6)$ & $0.02(3)$ & $0.00(0)$ & 99.3 & Fo80.2 \\
\hline & $\mathrm{Cpx}(3)$ & $47.8(5)$ & $1.16(2)$ & $7.47(60)$ & $0.42(9)$ & $6.70(13)$ & $0.14(17)$ & $13.5(9)$ & 21.1(9) & $0.51(19)$ & $0.04(5)$ & 98.7 & En43Wo48 \\
\hline & Plag(8) & $48.5(6)$ & $0.14(7)$ & $31.1(4)$ & $0.02(4)$ & $0.97(13)$ & $0.09(9)$ & $0.33(7)$ & $15.6(6)$ & $2.51(28)$ & $0.15(7)$ & 99.4 & An77Or1 \\
\hline \multicolumn{14}{|l|}{ STV315 } \\
\hline \multirow{2}{*}{$3-5$} & $\mathrm{Gl}(7)$ & $53.0(1)$ & $0.81(9)$ & $17.7(13)$ & $0.02(1)$ & $7.79(31)$ & $0.15(11)$ & $6.73(11)$ & $10.9(2)$ & $2.53(16)$ & $0.37(3)$ & 92.4 & Mg\#66.0 \\
\hline & $\mathrm{Ol}(6)$ & $39.8(2)$ & $0.01(2)$ & $0.04(2)$ & $0.06(8)$ & $14.6(2)$ & $0.2(6)$ & $44.3(4)$ & $0.24(7)$ & $0(0)$ & $0.03(4)$ & 99.2 & Fo84.4 \\
\hline $3-6$ & $\mathrm{Gl}(3)$ & $54.6(1)$ & $1.22(1)$ & $17.7(1)$ & $0.06(4)$ & $9.26(17)$ & $0.18(5)$ & $4.59(15)$ & $8.81(15)$ & $2.90(18)$ & $0.67(6)$ & 93.7 & Mg\#51.9 \\
\hline
\end{tabular}




\begin{tabular}{|c|c|c|c|c|c|c|c|c|c|c|c|c|c|}
\hline \multirow[t]{5}{*}{ Charge } & Phase & $\mathrm{SiO}_{2}$ & $\mathrm{TiO}_{2}$ & $\mathrm{Al}_{2} \mathrm{O}_{3}$ & $\mathrm{Cr}_{2} \mathrm{O}_{3}$ & $\mathrm{FeO}_{\mathrm{t}}$ & MnO & MgO & $\mathrm{CaO}$ & $\mathrm{Na}_{2} \mathbf{O}$ & $\mathrm{K}_{2} \mathrm{O}$ & Total $^{\mathrm{a}}$ & mol\% \\
\hline & $\mathrm{Ol}(5)$ & $37.5(6)$ & $0.03(2)$ & $0.07(9)$ & $0.03(4)$ & 22.3(4) & $0.34(12)$ & $39.0(4)$ & $0.30(9)$ & $0.03(3)$ & $0.02(2)$ & 99.6 & Fo75.7 \\
\hline & Cpx(4) & $50.0(9)$ & $0.67(13)$ & $5.10(69)$ & $0.21(2)$ & $72(38)$ & $0.11(13)$ & $15.5(7)$ & $18.7(8)$ & $0.31(4)$ & $0.01(3)$ & 99.3 & En47Wo40 \\
\hline & $\operatorname{Plag}(1)$ & 50.4 & 0.07 & 30.6 & 0.05 & 0.84 & 0.08 & 0.28 & 14.8 & 3.00 & 0.10 & 100.2 & An73Or1 \\
\hline & Opx(5) & $52.8(8)$ & $0.24(8)$ & 3.98 & $0.14(8)$ & $12.6(4)$ & $0.19(14)$ & 26.6(9) & $2.41(27)$ & $0.10(8)$ & $0.01(1)$ & 99.1 & En75Wo5 \\
\hline \multicolumn{14}{|c|}{ Run $6,4,147$ bars, $1,155^{\circ} \mathrm{C}, \mathrm{fH}_{2}=14.0$ bars, $13 \mathrm{~h}, \mathrm{XNi}=0.43, \mathrm{AgPd}$ capsules } \\
\hline \multicolumn{14}{|l|}{ STV301 } \\
\hline \multirow{3}{*}{$6-1$} & $\mathrm{Gl}(14)$ & $49.3(7)$ & $1.25(9)$ & $17.4(2)$ & $0.06(5)$ & $20(21)$ & $0.15(8)$ & $7.82(24)$ & $12.5(2)$ & $2.66(10)$ & $0.58(3)$ & 93.5 & Mg\#68.1 \\
\hline & $\mathrm{Ol}(5)$ & $39.7(3)$ & $0.01(2)$ & $0.22(14)$ & $0.05(5)$ & $13.3(6)$ & $0.24(11)$ & 4) & $0.35(11)$ & $0.02(3)$ & $0.01(2)$ & 99.7 & Fo86.0 \\
\hline & $\mathrm{Sp}(2)$ & $0.79(10)$ & $0.86(0)$ & $36.8(3)$ & 25.2(3) & $19.3(5)$ & $0.18(13)$ & $15.7(3)$ & $0.31(7)$ & $0.01(1)$ & $0.00(0)$ & 99.1 & Cr\#31.5 \\
\hline \multirow{4}{*}{$6-2$} & $\operatorname{Gl}(6)$ & 49.7 & 0) & 17 & (5) & (70) & 8) & 8) & 5) & 20) & (7) & 6.8 & 56.6 \\
\hline & $\mathrm{Ol}(13$ & $39.1(4)$ & 0.0 & 0 . & (6) & 17 & ) & 42 & $0.43(10)$ & 0.0 & $0.01(2)$ & 99.7 & Fo81.7 \\
\hline & Cpx(7) & $48.2(5)$ & $0.94(10)$ & $7.29(61)$ & $0.51(19)$ & $6.90(71)$ & $0.14(11)$ & 14.7(3) & $19.8(6)$ & $0.48(8)$ & $0.06(5)$ & 99.0 & En46Wo4 \\
\hline & $\operatorname{Plag}(2$ & $49.9(3)$ & $0.11(6)$ & $29.9(6)$ & $0.03(4)$ & $0.79(1)$ & $0.12(0)$ & $0.41(8)$ & $14.4(3)$ & $3.23(8)$ & $0.24(4)$ & 99.1 & An70Or1 \\
\hline \multicolumn{14}{|l|}{ STV315 } \\
\hline $6-4$ & $\operatorname{Gl}(5)$ & $52.3(5)$ & $0.83(8)$ & 17.1(2) & $0.04(4)$ & $8.16(18)$ & $0.19(8)$ & $7.67(12)$ & $10.8(3)$ & $2.50(8)$ & $0.39(4)$ & 94.9 & $\mathrm{Mg} \# 67.1$ \\
\hline \multirow{4}{*}{$6-5$} & $\mathrm{Gl}(4)$ & $52.6(3)$ & $1.14(8)$ & $16.6(1)$ & $0.04(7)$ & $9.6(2)$ & $0.3(1)$ & $6.54(6)$ & $10.0(2)$ & $2.72(9)$ & $0.49(9)$ & 97.1 & $\mathrm{Mg} \# 58.1$ \\
\hline & Opx(6) & $53.6(5)$ & $0.25(5)$ & $2.97(35)$ & $0.28(10)$ & $11.2(2)$ & $0.26(11)$ & $27.9(5)$ & $2.63(19)$ & $0.05(3)$ & $0.01(1)$ & 99.1 & En78Wo5 \\
\hline & Cpx(5) & $51.8(4)$ & $0.44(7)$ & $4.92(81)$ & $0.18(7)$ & $8.38(65)$ & $0.20(5)$ & $18.2(81)$ & $14.7(13)$ & $0.42(12)$ & $0.06(5)$ & 99.3 & En54Wo3 \\
\hline & $\operatorname{Plag}(5)$ & $50.7(4)$ & $0.06(5)$ & $29.8(5)$ & $0.04(5)$ & $0.83(17)$ & $0.04(4)$ & $0.44(20)$ & $13.9(3)$ & $3.36(12)$ & $0.10(2)$ & 99.3 & An69Or1 \\
\hline \multicolumn{14}{|c|}{ Run 7, 4204 bars, $1198^{\circ} \mathrm{C}, \mathrm{fH}_{2}=1.7$ bars, $25 \mathrm{~h}, \mathrm{XNi}=0.12$, AgPd capsules } \\
\hline \multicolumn{14}{|l|}{ STV301 } \\
\hline \multirow{3}{*}{$7-2$} & $\operatorname{Gl}(5)$ & $48.7(2)$ & $1.11(7)$ & $15.9(2)$ & $0.02(5)$ & $8.89(18)$ & $0.12(6)$ & $10.8(3)$ & $11.7(2)$ & $2.29(10)$ & $0.52(4)$ & 92.8 & $\mathrm{Mg} \# 78.0$ \\
\hline & $\mathrm{Ol}(2)$ & $42.0(1)$ & $0(0)$ & $0.17(20)$ & $0.01(1)$ & $8.97(30)$ & $0.14(11)$ & $48.3(1)$ & $0.28(3)$ & $0.02(3)$ & $0.02(1)$ & 99.9 & Fo90.5 \\
\hline & $\operatorname{Sp}(1)$ & 0.33 & 0.64 & 25.0 & 29.3 & 25.4 & 0.05 & 15.6 & 0.22 & 0 & 0.03 & 96.6 & $\mathrm{Cr} \# 44.0$ \\
\hline $7-3$ & $\mathrm{Gl}(5)$ & $49.0(2)$ & $1.24(6)$ & $16.8(2)$ & $0.02(4)$ & $8.51(29)$ & $0.18(8)$ & $8.83(19)$ & 12.3(1) & $2.47(12)$ & $0.60(4)$ & 96.1 & $\mathrm{Mg} \# 72.9$ \\
\hline
\end{tabular}




\begin{tabular}{|c|c|c|c|c|c|c|c|c|c|c|c|c|c|}
\hline Charge & Phase & $\mathrm{SiO}_{2}$ & $\mathrm{TiO}_{2}$ & $\mathrm{Al}_{2} \mathrm{O}_{3}$ & $\mathrm{Cr}_{2} \mathrm{O}_{3}$ & $\mathrm{FeO}_{\mathrm{t}}$ & MnO & MgO & $\mathrm{CaO}$ & $\mathrm{Na}_{2} \mathrm{O}$ & $\mathrm{K}_{2} \mathrm{O}$ & Total $^{\mathbf{a}}$ & mol\% \\
\hline & $\mathrm{Ol}(1)$ & 41.7 & 0.03 & 0.08 & 0.17 & 11.6 & 0.14 & 46.9 & 0.25 & $0(0)$ & 0.02 & 100.9 & Fo87.8 \\
\hline & $\mathrm{Sp}(1)$ & 0.23 & 0.54 & 35.4 & 26.1 & 20.5 & 0.24 & 16.5 & 0.38 & 0 & 0 & 99.9 & $\mathrm{Cr} \# 33.1$ \\
\hline \multicolumn{14}{|l|}{ STV315 } \\
\hline $7-4$ & $\mathrm{Gl}(4)$ & $52.8(3)$ & $0.79(2)$ & $16.8(3)$ & $0.04(7)$ & $8.23(39)$ & $0.09(6)$ & $7.73(7)$ & $10.70(7)$ & $2.40(20)$ & $0.36(5)$ & 93.3 & Mg\#73.3 \\
\hline $7-5$ & $\mathrm{Gl}(4)$ & $52.6(5)$ & $0.77(5)$ & $17.2(1)$ & $0.01(1)$ & $8.25(22)$ & $0.17(5)$ & $7.61(6)$ & $10.5(2)$ & $2.60(21)$ & $0.40(3)$ & 95.9 & $\mathrm{Mg} \# 71.3$ \\
\hline $7-6$ & $\mathrm{Gl}(4)$ & $52.8(5)$ & $0.76(5)$ & $17.1(1)$ & $0.06(1)$ & $7.96(22)$ & $0.19(5)$ & $7.62(6)$ & $10.5(2)$ & $2.62(21)$ & $0.40(3)$ & 97.5 & $\mathrm{Mg} \# 70.0$ \\
\hline \multicolumn{14}{|c|}{ Run $1,9,577$ bars, $1,044^{\circ} \mathrm{C}, \mathrm{fH}_{2}=6.0$ bars, $17 \mathrm{~h}, \mathrm{XNi}=0.15$} \\
\hline \multicolumn{14}{|c|}{ STV301 } \\
\hline \multirow{4}{*}{$1-9$} & $\mathrm{Gl}(5)$ & $64.5(6)$ & $0.36(5)$ & $22.6(22)$ & $0.07(8)$ & $0.75(13)$ & $0.00(1)$ & $0.56(11)$ & $8.07(24)$ & $2.15(25)$ & $0.88(3)$ & 84.5 & Mg\#65.7 \\
\hline & $\operatorname{Amph}(10)$ & $42.7(5)$ & $0.88(11)$ & $12.8(2)$ & $0.11(10)$ & $7.07(47)$ & $0.12(10)$ & $16.9(4)$ & $11.9(2)$ & $2.19(9)$ & $0.43(4)$ & 95.1 & $\mathrm{Mg}=0.809$ \\
\hline & Cpx(3) & $48.9(6)$ & $0.54(3)$ & $6.26(34)$ & $0.08(2)$ & $6.39(11)$ & $0.19(7)$ & $14.2(2)$ & $21.4(2)$ & $0.42(4)$ & $0.03(4)$ & 98.7 & En44Wo48 \\
\hline & $\operatorname{Mt}(3)$ & $0.21(9)$ & $7.3(2)$ & $3.08(14)$ & $0.6(17)$ & $71.3(4)$ & $1.0(2)$ & $3.71(7)$ & $0.32(13)$ & $0(0)$ & $0.01(2)$ & 87.6 & Cr\#11.8 \\
\hline \multicolumn{14}{|l|}{ STV315 } \\
\hline \multirow{4}{*}{$1-5$} & $\mathrm{Gl}(3)$ & $64.4(4)$ & $0.23(5)$ & $22.1(1)$ & $0.02(5)$ & $0.55(9)$ & $0.01(1)$ & $0.53(4)$ & $8.11(4)$ & $3.18(8)$ & $0.86(13)$ & 84.0 & Mg\#71.9 \\
\hline & $\operatorname{Amph}(8)$ & $43.3(5)$ & $0.84(11)$ & $12.7(4)$ & $0.08(9)$ & $6.79(78)$ & $0.10(10)$ & $17.1(2)$ & $11.9(3)$ & $2.14(11)$ & $0.44(6)$ & 95.4 & $\mathrm{Mg} \#=0.818$ \\
\hline & $\mathrm{Cpx}(1)$ & 48.6 & 0.49 & 6.90 & 0.03 & 6.67 & 0.12 & 14.5 & 21.3 & 0.41 & 0.04 & 99.1 & En45Wo47 \\
\hline & $\operatorname{Mt}(3)$ & $0.24(24)$ & $7.49(30)$ & $3.03(7)$ & $0.56(17)$ & $72.9(5)$ & $0.76(22)$ & $3.88(17)$ & $0.31(4)$ & $0.01(2)$ & $0.02(2)$ & 89.2 & Cr\#11.3 \\
\hline
\end{tabular}

Gl glass, Ol olivine, Plag plagioclase, Opx orthopyroxene, Cpx clinopyroxene, Sp Cr-Al spinel, Mt magnetite, Amph amphibole

${ }^{a}$ Glass analyses normalised to $100 \%$ anhydrous, with all $\mathrm{Fe}$ as $\mathrm{FeO}$. Unnormalized total is reported

${ }^{\mathrm{b}}$ Number of microprobe analyses

${ }^{\mathrm{c} O n e}$ standard deviation in terms of least unit cited

${ }^{\mathrm{d}}$ Composition estimated

$\mathrm{Mg} \#$ of glass calculated as at. $100 * \mathrm{MgO} /(\mathrm{MgO}+\mathrm{FeO}) . \mathrm{FeO}$ is determined from the electron microprobe analysis of the glass using the expression of $\mathrm{Kress}$ and Carmichael (1991) and P-T- $\mathrm{fO}_{2}$ data from Table 3 . Mg\# of STV301 and STV315 starting glasses are calculated at 1 bar, $1,400^{\circ} \mathrm{C}$ and log fO ${ }_{2}=-0.69$ (air). $\mathrm{Mg}$ of amphibole calculated as at. $\mathrm{MgO} /\left(\mathrm{MgO}+\mathrm{FeO}_{\text {total }}\right) . \mathrm{Fo}=100 *$ at. $\mathrm{Mg} /(\mathrm{Mg}+\mathrm{Fe})$ in olivine. $\mathrm{Cr} \#=100 *$ at. $\mathrm{Cr} /(\mathrm{Cr}+\mathrm{Al})$ in spinel. $\mathrm{En}=100 * \mathrm{at} . \mathrm{Mg} /(\mathrm{Mg}+\mathrm{Fe}+\mathrm{Ca}), \mathrm{Wo}=100 *$ at. $\mathrm{Ca} /(\mathrm{Mg}+\mathrm{Fe}+\mathrm{Ca})$ in pyroxene, calculated with $\mathrm{Fe}=\mathrm{Fe}^{2+}$ (Lindsley 1983). $\mathrm{An}=100 *$ at. $\mathrm{Ca} /(\mathrm{Ca}+\mathrm{Na}+\mathrm{K}), \mathrm{Or}=100 *$ at. $\mathrm{K} /(\mathrm{Ca}+\mathrm{Na}+\mathrm{K})$ in plagioclase 
Table 5 Calibration, formulation and parameters for the $\mathrm{Al}_{2} \mathrm{O}_{3}$ in melt hygrometer

$$
\mathrm{Al}_{2} \mathrm{O}_{3}=\mathrm{A}+\mathrm{B} /\left(\mathrm{T}^{\mathrm{C}}\right)+\mathrm{D}^{*} \mathrm{H}_{2} \mathrm{O}+\mathrm{E}^{*} \mathrm{SiO}_{2}+\mathrm{F}^{*} \mathrm{CaO}+\mathrm{G}^{*} \mathrm{MgO}+\mathrm{H}^{*} \mathrm{Na}_{2} \mathrm{O}+\mathrm{I}^{*} \mathrm{~K}_{2} \mathrm{O}
$$

$\mathrm{SiO}_{2}, \mathrm{Al}_{2} \mathrm{O}_{3}, \mathrm{CaO}, \mathrm{MgO}, \mathrm{Na}_{2} \mathrm{O}$ and $\mathrm{K}_{2} \mathrm{O}$ in wt\% (from glass major element composition normalized to $100 \%$ volatile-free), $\mathrm{H}_{2} \mathrm{O}$ in wt\%, $\mathrm{T}$ in ${ }^{\circ} \mathrm{C}$

\begin{tabular}{|l|l|l|l|l|l|l|l|l|}
\hline $\mathbf{A}$ & $\mathbf{B}$ & $\mathbf{C}$ & $\mathbf{D}$ & $\mathbf{E}$ & $\mathbf{F}$ & $\mathbf{G}$ & H & I \\
\hline 81.2265 & -362.5553 & 0.3565 & 0.7632 & -0.4757 & -0.3524 & -0.9902 & -0.6634 & -0.1160 \\
\hline
\end{tabular}

